\title{
EQUATORIAL OBSERVATIONS.
}

1893-1907.

$28167^{\circ}-\mathrm{VOL} 6-\mathrm{II}-\mathrm{II}$ 


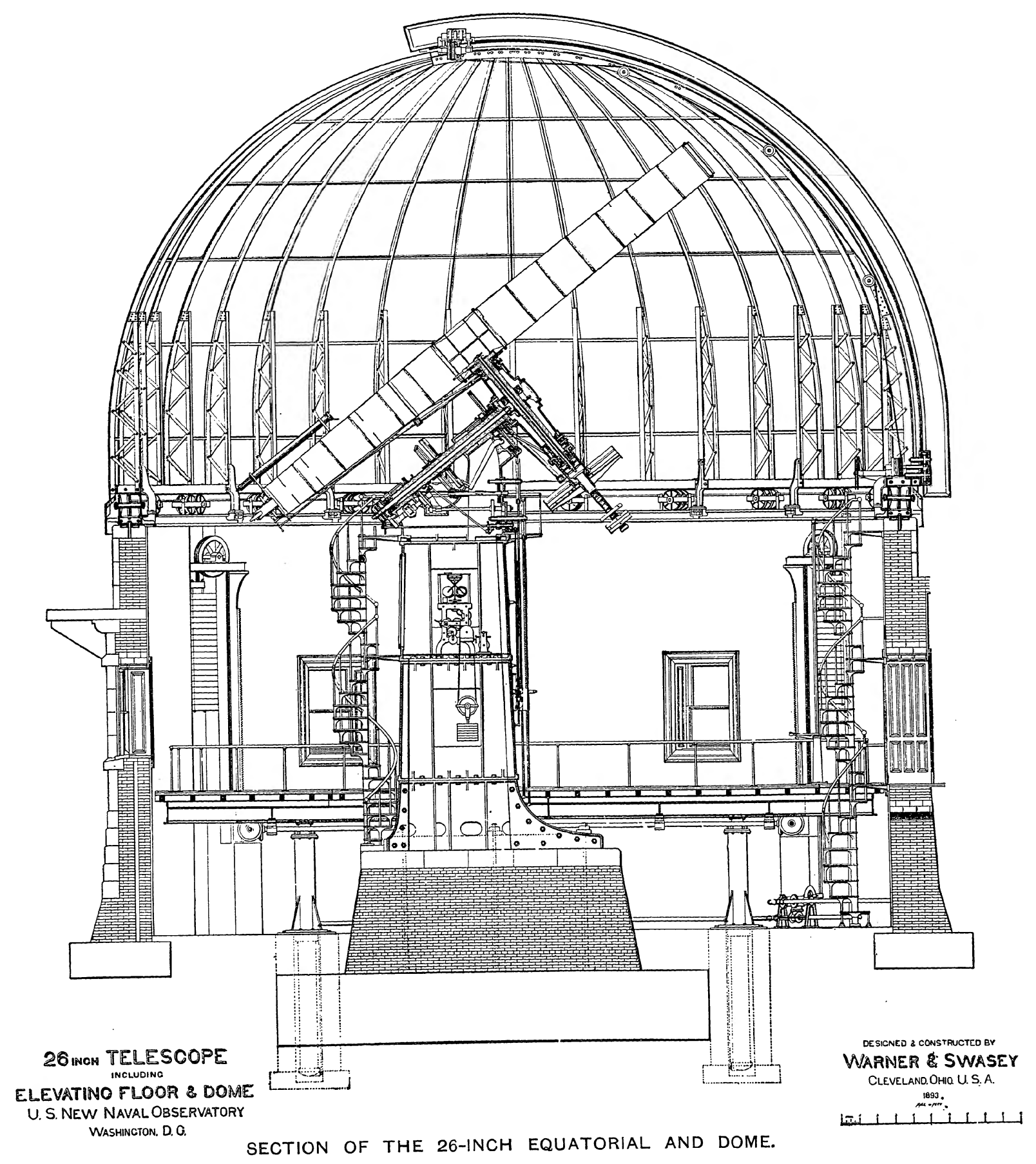




\section{INTRODUCTION.}

By J. C. Hammond.

The present volume contains the observations made with the equatorials of this observatory from the time of its removal to the present site in 1893 to the beginning of the year 1908, with the exception of the observations of Eros for parallax in I900-I9OI. The latter have already been published in the Publications of the United States Naval Observatory, Second Series, Volume III, Part I. The instruments in use have been the two equatorials of 26 -inches and 12 -inches aperture, respectively. The latter instrument had a 9.6-inch object-glass until December 19, I895, after which date the r2-inch object-glass has been used. These instruments have been under the supervision of the following astronomers:

\section{6-INCH EQUATORIAL.}

Prof. of Math. S. J. BRown, U. S. N., I893-December 15, I899.

Prof. of Math. T. J. J. SEE, U. S. N., December I8, I899-September 20, 1902.

Prof. of Math. A. N. Skinner, U. S. N., September 20, I902-July Io, I907.

Prof. of Math. W. S. Eichelberger, U.S. N., July Io, r907-December 3I, I907. I2-INCH EQUATORIAL.

Prof. of Math. Edgar Frisby, U. S. N., I893-May 22, I899.

Prof. of Math. T. J. J. SEE, U. S. N., Ju1y 16, I899-December 17, 1899.

Prof. of Math. S. J. Browin, U. S. N., December I7, I899-March 25, I9oI.

Assistant Astronomer, ThEo I. KING, March 3O, I 90 I-November I 5, 1903.

Prof. of Math. A. N. Skinner, U. S. N., November I5, r903-July Io, I907.

Prof. of Math. W. S. Eichelberger, U. S. N., July Io, I907-December 31, I907"

The general plan of work has been to observe, (I) the satellites and the diameters of planets, (2) some of the interesting and difficult double stars, (3) the minor planets and comets, and (4) the occultations of stars by the Moon. The 26-inch has been devoted exclusively to observing the fainter and more difficult objects. Continuity in the observations of the satellites of Saturn, Uranus, and Neptune has been considered especially important. The different classes of observations are printed separately and a summary of each class is given in this introduction. 


\section{DESCRIPTION OF THE INSTRUMENTS.}

The 26-inch equatorial was dismounted at the old Naval Observatory in December, I892, and a number of its parts, including the two finders and the two microscopes for reading the declination circle, were sent to The WARNER and SwASEy Company, of Cleveland, Ohio, to be fitted to the new mounting which they were constructing for the new Naval Observatory. This new mounting was completed and the 26-inch objective with its cell attached in June, I893. Some time was spent in making the necessary adjustments and in arranging the illumination, hence the telescope was not ready for regular observing until December, 1893 .

The 9.6-inch equatorial was dismounted at the old observatory in October, I892, while a new I2-inch equatorial mounting was in course of construction at the new observatory by GEORGE N. SAEGMÜlLER, formerly of Washington, D. C. The new mounting was completed in November, I892, and the old 9.6-inch objective was temporarily adapted for use with it. This objective continued to be used until December I9, I895, when it was replaced by a new I 2-inch objective made by ALVAN CLARK and Sons. The instrument was ready for regular observing in October, r893.

The general features of these instruments, which will be described somewhat in detail, can be seen from the accompanying plates.

I. THE $26-\mathrm{INCH}$ EQUATORIAL.

The objective.-The objective was made by ALVAN CLARK and Sons in I873. A complete investigation of it by Prof. E. S. HoLDEN, U. S. N., may be found in the Washington Astronomical Observations for I877, Volume XXIV, Appendix I. The following data are extracted from this appendix:

\begin{tabular}{|c|c|}
\hline Clear aperture .... . & 26. oo inches. \\
\hline Principal focal length........... & 389.66 inches. (at $32^{\circ} \mathrm{F}$.) \\
\hline Thickness of crown glass at center. & I. 884 inches. \\
\hline Thickness of flint glass at center. . . . . & o. 958 inches. \\
\hline Thickness of objective in cell at center. & 2. $87 \mathrm{r}$ inches. \\
\hline Weight of crown glass $\ldots \ldots \ldots \ldots$ & 70 pounds. \\
\hline Weight of flint glass. . & rio pounds. \\
\hline
\end{tabular}

The two lenses are separated by three pieces of tin-foil at their edges. The magnitude of the faintest star, on ARGELANDER's scale extended, that can be seen with this objective is $\mathrm{r} 6.3$, and its separating power is, according to the formula of DAWES, O."I8.

The objective has been twice removed from its cell and cleaned, once on December 7, 1894, and again on November 12, I897.

The column.-The column is of iron cast in three sections, ribbed on the inside to secure stiffness and accurately fitted and bolted together. The lower section is 3 feet 2 inches high and has a base measuring 12 feet on the north and south line by Io feet on the east and west. It is bolted rigidly to the capstone of the masonry pier. The middle section of the column is 6 feet ro inches high. At the base it measures 6 feet 6 inches on the north and south line by 3 feet $8 \frac{x}{2}$ inches on the east and west. This section has two doors, one on the east side and another on the west, for access to the chamber in the lower part of the column. The upper section 


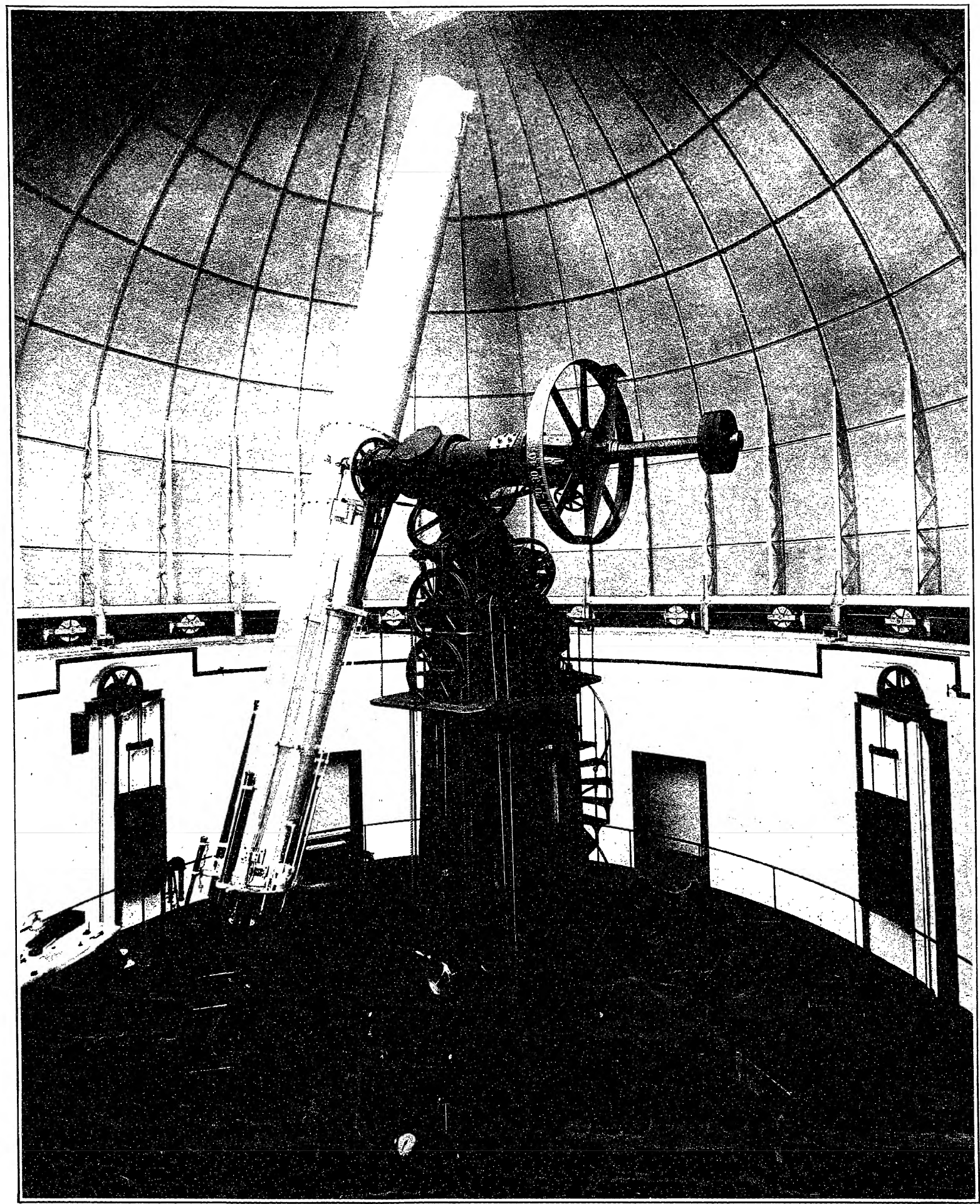

THE 26-INCH EQUATORIAL-SHOWING NORTH SIDE OF COLUMN WITH SETTING DIAL AND MICROSCOPES FOR READING THE HOUR CIRCLE. 
is 6 feet ro inches in height and measures at the base 6 feet $\mathrm{x} 3 / 4$ inches on the north and south line by 3 feet $4 \frac{1}{4}$ inches on the east and west. The top of this section, which is also the top of the column, is 5 feet $9^{\mathrm{I}} / 2$ inches on the north and south line by 3 feet on the east and west. This section contains two glass doors, one on the east side and one on the west, for access to the driving clock which is situated within. The total height of the column above the capstone is I6 feet Io inches.

The pier.-The pier which supports the column is of solid concrete, i 8 feet by 2 I feet at the base, and 16 feet in height. It is sunk I 2 feet below the basement into the earth. The pier is I 72 feet directly south of the center of the clock room, which determines the latitude and longitude of this observatory.

The equatorial head.-This consists of a single casting of great solidity to carry the polar axis and its attachments. It is bolted to the top of the column and provided with means for adjustment in altitude and azimuth. The adjustment for altitude became exhausted, and a steel plate O.I25 inch thick was inserted under the northern adjusting wedge, so as to bring the adjusting screws back to the middle of their runs. This change was made by The WARNER and SwASEx Company in June, 1896.

Around the head is placed an iron balcony with a brass railing, giving easy access to the working parts of the instrument. This balcony is reached by an iron spiral staircase on the south side of the column, with a landing at the top of the central section, from which admittance can be had to the driving clock by means of a door through the south side of the upper section.

The axes. - The polar and declination axes are of hard, forged steel. The former is 8 feet 6 inches long and has a diameter of 9 inches at the upper end, tapering to 8 inches at the lower end. It is bored out $2 \frac{\mathrm{r}}{2}$ inches through the center.

The declination axis is approximately 7 feet 6 inches in length with a diameter of 8 inches at the upper end, tapering to 7 inches at the tube. It is bored out in a similar manner as the polar axis. The friction of both axes in their bearings, as well as their end thrusts, are relieved by antifriction mechanisms.

The tube.-The tube is of hard rolled sheet steel, except the central section, which is of cast steel for attachment to the head of the declination axis. It is made up of sections, fourteen in all, including the central section. The three sections on each side of the central section are o.r 34 inch thick. The next two sections on each side are 0.094 inch thick. The outer sections, one at the eye-end and two at the object-glass end, are 0.072 inch thick. These sections are solidly riveted together and the tube tapers each way from the center. The diameter at the center is approximately 2 feet 8 inches, at the eye-end 2 feet, and at the object-glass end 2 feet 5 inches. The tube is approximately 372 inches long.

The circles. - The instrument is supplied with finely divided silver circles both in hour angle and declination. The circle for reading the hour angle is 2 feet 4 inches in diameter and is divided to 20 seconds of time. It is read by verniers to I second of time.

The declination circle is also 2 feet 4 inches in diameter, and is divided to 5 minutes of arc. It is read to io seconds of arc by means of verniers. 
For reading the hour circle there are two telescopes on the north side of the column, fixed to a slide which moves up and down with the floor. The declination circle is read by two telescopes attached to the tube near the eye-end.

There are also coarse circles in both hour angle and declination, and a dial which indicates directly the settings in right ascension and declination. This dial is attached to the slide mentioned above, and was designed by Prof. WM. Harkness, U. S. N.

The finders.-There are two finders of 5 inches and $2 \frac{1}{8}$ inches aperture, respectively. The larger one, by ALVAN CLARK and Sons, has a focal length of 78 inches, and is fastened to the tube near the eye-end and on the opposite side from the declination axis. The eyepiece generally used with this finder has a magnifying power of 35 diameters and a field of $I^{\circ} I^{\prime}$.

The smaller finder, by KAHLER, has a focal length of $2 \mathrm{I}$ inches. It is situated $60^{\circ}$ in position angle from the larger one and has an eyepiece magnifying about I 2 diameters and a field of over $3^{\circ}$. Both finders, as well as the two telescopes for reading the declination circie, were taken from the original mounting of the telescope.

The driving clock.-The driving clock is located in the upper section of the column and is driven by a weight which is wound up by hand. It has the ordinary type of double conical pendulum and is provided with an electric control. However, it has never been necessary to use the latter. The clock is so geared that the pendulum makes 90 revolutions per minute, and motion is communicated to the polar axis by means of a continuous worm gear of bronze. The worm screw is of steel. Extra gears are provided for changing from a sidereal rate to a mean solar or a mean lunar rate.

The driving clock has periodic errors, which are quite troublesome in making accurate measures. The most pronounced one has a period of exactly four minutes and an amplitude of about $I^{\prime \prime}$. This error seems to be superimposed upon another of longer period. The following diagrams have been plotted from settings of the movable micrometer wire on a star at intervals of 20 seconds of time while the clock was driving the telescope, on the night of September 25, I908. The settings for the upper diagram were made by Prof. AsapH HALL jr., U.S. N., and those for the lower one by Assistant Astronomer J. C. HAmmond. The ordinates are the readings of the micrometer and the abscissa are the times. A difference of roo in the micrometer readings corresponds to $\mathrm{I}^{\prime \prime}$. 


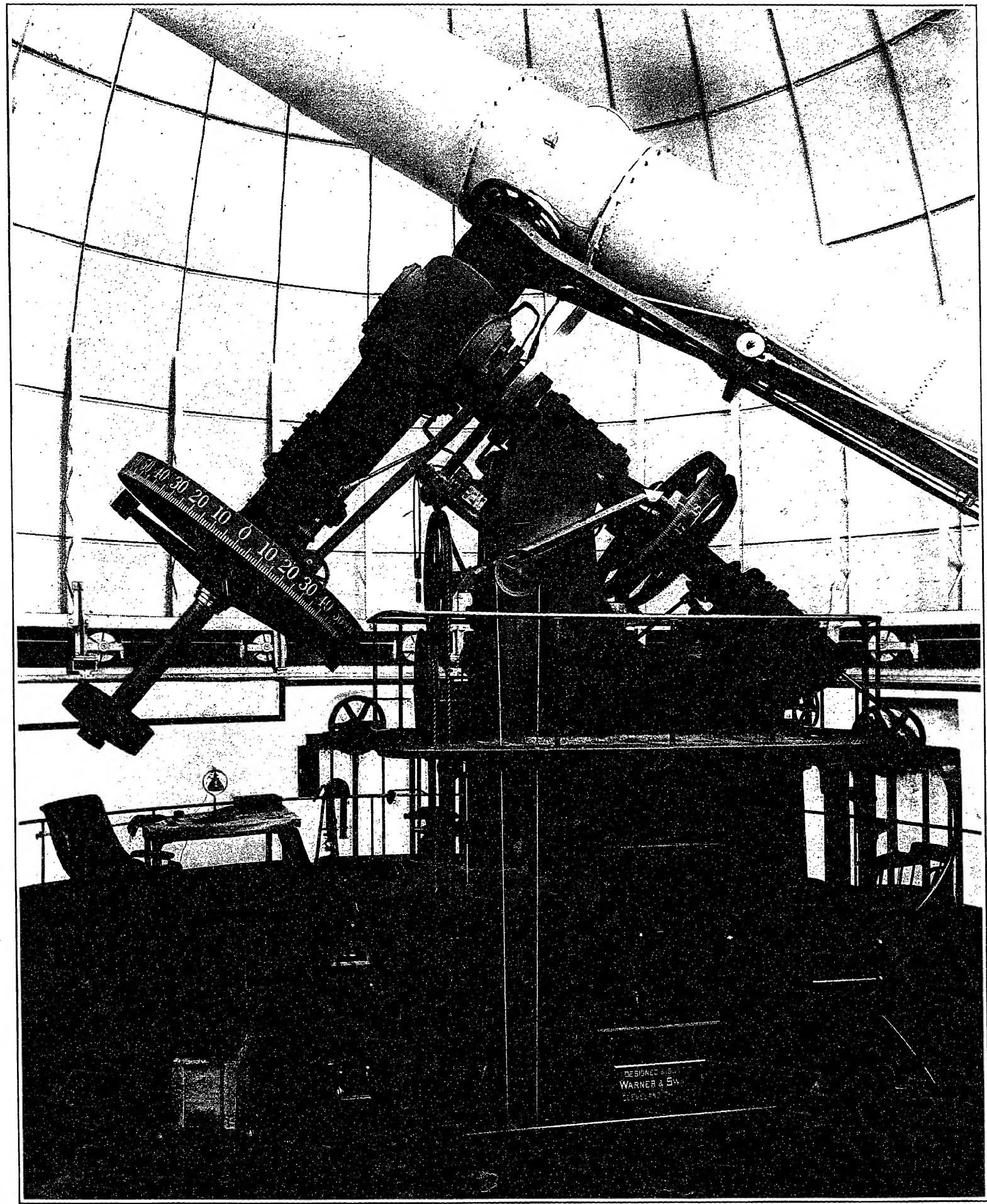

THE 26-INCH EQUATORIAL WITH VIEW OF THE DRIVING CLOCK. 


\section{Diagram Showing Periodic Errors of Driving Clock.}

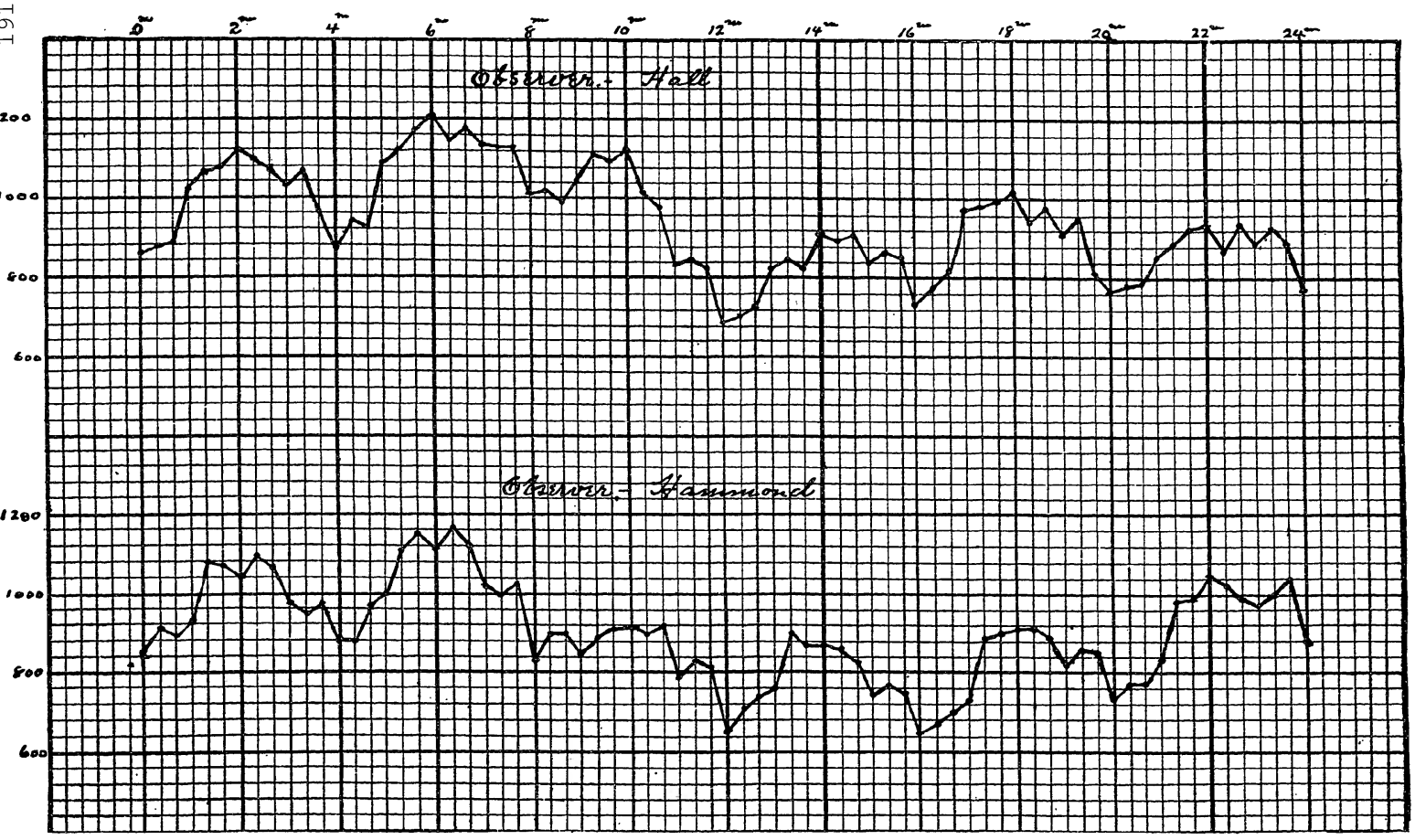

The error with a period of four minutes is very conspicuous. However, its cause is difficult to locate for the following reason:

A vertical shaft (A), carrying the governors and making 90 revolutions per minute, has on its base a small bevel gear (a) of 20 teeth. The latter works in another bevel gear (b) of 90 teeth on a horizontal shaft (B). This last revolves at the rate of 20 revolutions per minute and has on it another gear ( $\left.b^{\prime}\right)$ of 19 teeth which engages a gear (c) of 95 teeth on a shaft (C). The shaft (C) makes 4 revolutions per minute and has on it another gear $\left(c^{\prime}\right)$ of 24 teeth which works in a gear (d) of 96 teeth. The latter is on a shaft (D) making I revolution per minute. On (D) is another gear $\left(\mathrm{d}^{\prime}\right)$ of 24 teeth which engages a gear (e) of 96 teeth. The gear (e) is on a shaft $(\mathrm{E})$ making I revolution in four minutes. On $(\mathrm{E})$ is a small gear which connects with the drum carrying the driving weight and also another gear $\left(\mathrm{e}^{\prime}\right)$ of 72 teeth. The gear $\left(\mathrm{e}^{\prime}\right)$ works in a gear $(\mathrm{f})$ of 72 teeth on a shaft $(\mathrm{F})$. On this shaft $(\mathrm{F})$ is a gear $\left(\mathrm{f}^{\prime}\right)$ of 84 teeth which communicates motion to a gear $(\mathrm{g})$ of 84 teeth which in turn communicates motion to another gear (h) with 84 teeth. Gear $(\mathrm{h})$ is on a shaft $(\mathrm{H})$ which has on it a bevel gear $\left(\mathrm{h}^{\prime}\right)$ of 50 teeth engaging another $(\mathrm{k})$ of 50 teeth. The bevel gear $(\mathrm{k})$ is on the shaft $(\mathrm{K})$ which communicates the motion directly to the worm screw (L) by means of two auxiliary bevel gears $\left(\mathrm{k}^{\prime}\right)$ and $(1)$ of 50 teeth each.

Now the gears e, $e^{\prime}, \dot{f}, f^{\prime}, g, h, h^{\prime}, k, k^{\prime}$, and 1 , as well as the worm screw L, all run at the rate of $\mathrm{I}$ revolution in four minutes. The error may be caused by any one of the above gears, by the worm screw, or by the worm wheel itself; or it may be due to a combination of several or all of them. A thorough investigation is necessary to locate the trouble definitely. If, however, the four-minute error could 
by any means be eliminated, the remaining error would be of such a long period that it would not be troublesome.

Other details.-Rapid motion to the instrument in hour angle and declination is given by means of two ropes working over pulleys on the north side of the column. These are thrown out of gear when not in use. This arrangement is very convenient for operating a large telescope.

At the eye-end, convenient for use, are four handles which operate the clamps and slow motions. On December 7, I897, auxiliary gears were introduced to reduce the speeds of the slow motions.

PLATE V shows the eye-end of the telescope with the two finders, the two telescopes for reading the declination circle, the handles for operating the clamps and slow motions, the focussing rack and the micrometer.

The great equatorial building.-A general view of the building which contains this instrument is given by the frontispiece. The walls are of brick faced with rough white marble. On the north side of the building are two office rooms separated by a hall which leads directly to the dome.

During the summer of I899 the walls and floor of the basement and the cement pier were insulated from the basement by a double wall and floor of matched pine with heavy tarred paper between. The hydraulic apparatus for elevating the floor was also encased in the same way, so that the temperature of the basement may be kept nearly the same as that of the outside air. Previous to this, radiation from the massive stone walls, the pier, and cement floor caused troublesome air currents.

The following readings of three thermometers-one placed in the slit of the dome, one on top of the column, and one on the north side of the room-show the difference in temperature between the air outside and that inside the dome under various conditions.

\begin{tabular}{|c|c|c|c|c|c|c|c|c|c|c|c|}
\hline $\begin{array}{l}\text { Wash. } \\
\text { M:T. }\end{array}$ & Slit. & $\begin{array}{l}\text { Col- } \\
\text { umn. }\end{array}$ & $\begin{array}{l}\text { North } \\
\text { Side. }\end{array}$ & $\begin{array}{l}\text { Wash. } \\
\text { M. T. }\end{array}$ & Slit. & $\begin{array}{l}\text { Col- } \\
\text { umn. }\end{array}$ & $\begin{array}{l}\text { North } \\
\text { Side. }\end{array}$ & $\begin{array}{l}\text { Wash. } \\
\text { M. T. }\end{array}$ & Slit. & $\begin{array}{l}\text { Col- } \\
\text { umn. }\end{array}$ & $\begin{array}{l}\text { North } \\
\text { Side. }\end{array}$ \\
\hline \multicolumn{4}{|c|}{$\begin{array}{l}\text { I908, October i } 4 \text {. Shutters } \\
\text { opened at } 7^{\mathrm{h}}{ }_{30^{\mathrm{m}}}\end{array}$} & \multicolumn{4}{|c|}{$\begin{array}{l}\text { 1908, October I } 7 \text {. Shutters } \\
\text { opened at } 7^{\text {hh }}{ }_{20^{\mathrm{m}}}\end{array}$} & \multicolumn{4}{|c|}{$\begin{array}{l}\text { 1908, November } 12 \text {. Shutters } \\
\text { opened at } 4^{\mathrm{h}} \mathrm{O}^{\mathrm{m}}\end{array}$} \\
\hline$h m$ & $\circ$ & $\circ$ & 0 & $h \quad m$ & $\circ$ & $\circ$ & $\circ$ & $h \quad m$ & $\circ$ & $\circ$ & $\circ$ \\
\hline 922 & 54.9 & 56.0 & $5^{6 .} \mathrm{I}$ & $\begin{array}{ll}8 & 3\end{array}$ & 71.6 & 71.2 & 69.2 & 653 & $37 \cdot 7$ & 39.0 & 39. I \\
\hline 10 $3^{8}$ & 54.2 & 54.8 & $55 \cdot 5$ & 935 & 68.9 & 69.5 & 68.2 & $73 \mathrm{I}$ & $3^{6.9}$ & 38.6 & 38.5 \\
\hline I 234 & 51.0 & 52.6 & 53. I & Io 36 & 68.0 & 67.7 & 67.9 & 757 & 36.4 & 38.3 & 38.7 \\
\hline 1429 & 49. 7 & $5 \mathrm{I} \cdot 3$ & 5 I. 8 & \multirow{2}{*}{\multicolumn{4}{|c|}{$\begin{array}{l}\text { I908, October } 20 . \text { Shutters } \\
\text { opened at } 5^{\mathrm{h}} \mathrm{O}^{\mathrm{m}}\end{array}$}} & 828 & 34.7 & 36.8 & 37.9 \\
\hline \multirow{2}{*}{\multicolumn{4}{|c|}{$\begin{array}{l}\text { 1908, October } 15 . \text { Shutters } \\
\text { opened at } 4^{\mathrm{h}} 5^{\mathrm{m}}\end{array}$}} & & & & & 946 & $\begin{array}{l}34 \cdot 1 \\
34 \cdot 5\end{array}$ & $\begin{array}{l}35 \cdot 9 \\
36.3\end{array}$ & $\begin{array}{l}37 \cdot 1 \\
37 \cdot 1\end{array}$ \\
\hline & & & & IO II & 47.0 & 49.4 & 50.3 & Io 33 & 34.6 & $36 . x$ & $37 . \mathrm{I}$ \\
\hline 719 & 68.5 & 67.4 & 65.0 & 126 & 45.0 & 47.8 & $47 \cdot 9$ & I I 42 & 34.4 & 35.5 & 36.2 \\
\hline 810 & $67 . \mathrm{I}$ & 66.3 & 64.5 & $13 \circ$ & $44 \cdot 5$ & $47 \cdot \mathrm{I}$ & $17 .=$ & 1340 & 32.8 & 34.2 & 35.0 \\
\hline $\begin{array}{r}928 \\
9\end{array}$ & 65.7 & 64.8 & 63.9 & & & & & & & & \\
\hline I0 47 & 63.3 & 63.0 & 63.0 & \multirow{2}{*}{\multicolumn{4}{|c|}{$\begin{array}{l}\text { 1908, October } 26 . \text { Shutters } \\
\text { opened at } 4^{\text {h }} \mathrm{O}^{m}\end{array}$}} & & & & \\
\hline 1238 & 60.4 & 61.0 & 61.0 & & & 65.5 & & & & & \\
\hline \multirow{2}{*}{\multicolumn{4}{|c|}{$\begin{array}{l}\text { 1908, October 16. Shutters } \\
\text { opened at } 7^{\mathrm{b}} 5^{\mathrm{m}}\end{array}$}} & 86 & 65.6 & 65.2 & 65.2 & & & & \\
\hline & & & & 853 & 64.0 & 64.7 & $65 . \mathrm{I}$ & & & & \\
\hline $75^{8}$ & 68.5 & 68.8 & 67.0 & $95^{8}$ & 63.0 & 63.6 & 64.0 & & & & \\
\hline 944 & $67 \cdot x$ & $67 \cdot 3$ & 66.3 & II 16 & $6 \mathrm{I} .5$ & 63.0 & 6.3 .9 & & & & \\
\hline I4 6 & 60.6 & 61.7 & 61.8 & 1217 & 61.0 & 62.5 & 62.8 & & & & \\
\hline
\end{tabular}




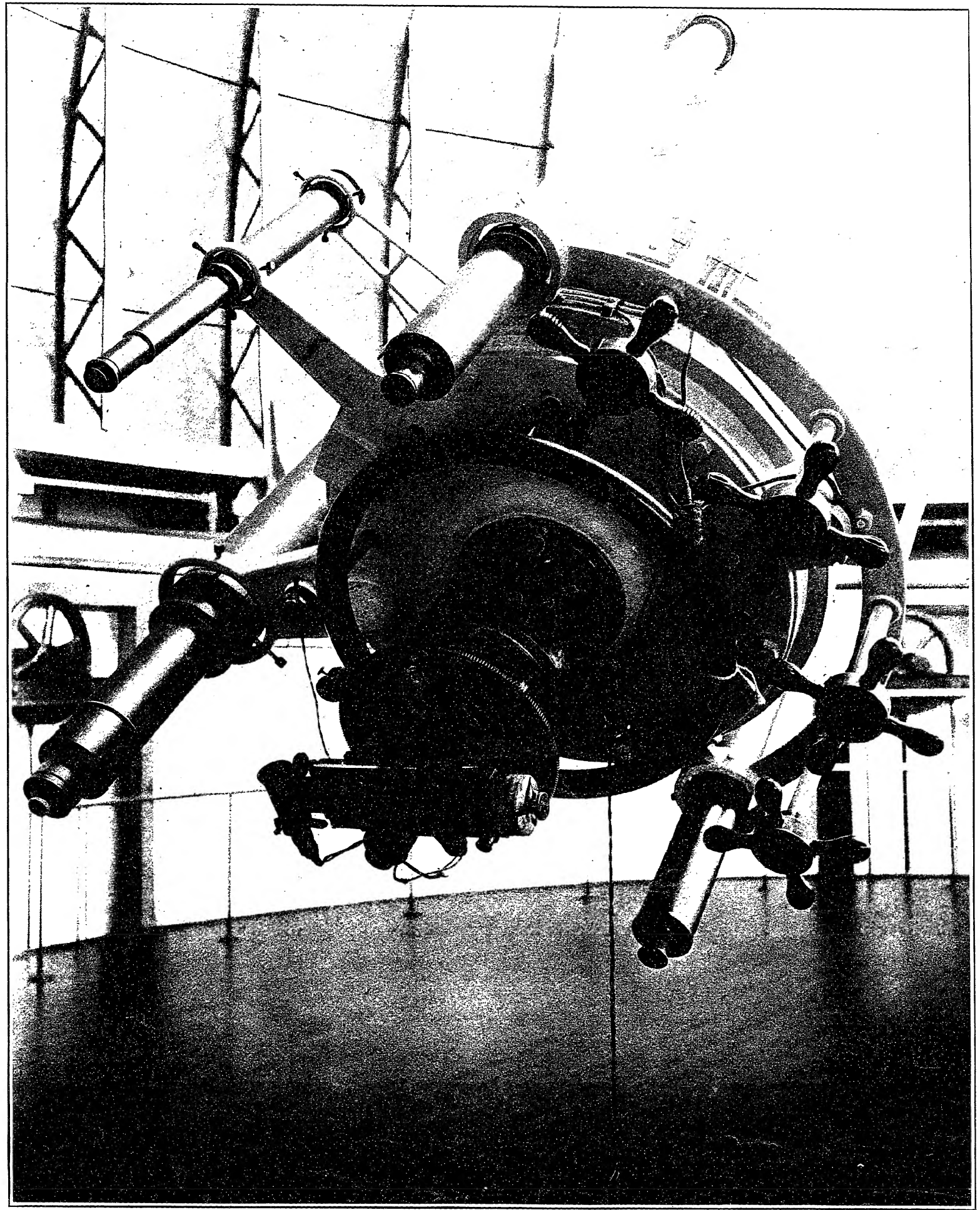

THE EYE-END OF THE 26-INCH EQUATORIAL-SHOWING THE MICROMETER, TWO FINDERS, TWO MICROSCOPES FOR READING THE DECLINATION CIRCLE, CLAMP AND SLOW-MOTION HANDLES, AND FOCUSING RACK. 
The elevating floor.-The elevating floor, designed and constructed by The WARNER and SWASEY Company, is circilar, 40 feet 6 inches in diameter, and has a rise of $I 2$ feet. It is raised by means of four hydraulic rams, each having a piston 8 inches in diameter with a I2-foot stroke. These rams are controlled by a valve actuated by a lever on the northwest side of the floor.

In order to keep the floor always level while in motion, two parallel shafts are provided, geared so that both shall revolve at the same speed. On the ends of these two shafts are four steel pinions, working in perpendicular racks bolted to iron plates in the wall. These racks also serve as guides to the floor in moving up or down.

The floor is nearly counterbalanced by means of cast-iron weights working up and down in six recesșes in the wall. The water pressure for working the rams was at first obtained from a pair of steam pumps situated in the basement of the main building. When the new high-service reservoir was connected with the city mains, it was found that the pressure in them was about 74 pounds per square inch, which is sufficient to operate the floor. Accordingly, on December 7, I896, the use of the steam pumps was discontinued and connection was made with the city mains. This direct water pressure, reenforced at present by air . pressure from a tank in the basement of the main building, has been in use continuously to the present time.

On May 24, I898, a small relief cock was inserted in the top of each ram for releasing the air which collects there and which would cause the floor to move in an irregular manner.

In September, I900, a new control valve was installed to control the motion of the rams, and the floor has worked satisfactorily since that time.

The dome. - The steel dome, made by The WARner and Swasey Company, is 45 feet in diameter with a slit 6 feet 2 inches wide running from the base to a point a few feet beyond the zenith. When the shutters are opened to the widest extent, there is a clear aperture of 5 feet 8 inches. The dome is carried on wheels which run on a circular track. The latter is double, the distance between the centers being about I 3 inches. The wheels are arranged in sets of three, the wheels of each set being fixed solidly on one axis. The outer and inner wheels of each set roll on the double track, while the middle wheel carries the dome. There are in all 22 sets of wheels, equally spaced around the track and rigidly connected by rods. The diameter of the inner wheels is about $I_{5}$ inches.

The dome is kept in place by horizontal guide wheels running between the two tracks. Nine claws projecting under the inner track serve to protect the dome from being blown from the track.

In August, I899, cork paint was applied to the inner surface of the dome to prevent moisture condensing on it and dripping on the instrument.

The dome may be turned by means of a hand rope, the motion of the rope being originally ten times that of the circumference of the dome. In June, I896, the gearing was altered so that the motion of the rope was only five times that of the dome. Under these conditions, a weight of r9 pounds is sufficient to start it.

In October, I907, a motor for turning the dome was installed by Mr. J. E. HURLEY, of Washington, D: C. (See Plate VI.) This motor is a single-phase alternating-current induction motor of one horse-power, made by the WESTINGHOUSE Electric Co. of Pittsburg. It runs at a speed of 1,700 revolutions per minute, and is 
connected with a sprocket wheel keyed on the hand-rope shaft. The speed is reduced by intermediate gears, so that the hand-rope wheel makes only 35 revolutions per minute and the motion is transmitted by means of the RENOLD silent-chain gears, which will run in either direction.

The motor is reversible, and the dome can be turned completely around in either direction in about three minutes. A cast-iron bracket, fastened to the top of the wall near the hand-rope wheel, supports the motor and intermediate gears.

No trouble has been experienced from either the motor or the chain gears, and both have performed with entire satisfaction.

Illumination of dome and instrument.-During the fiscal year ending June 30 , I90I, the illumination of the dome and instrument was entirely rearranged and materially improved by Assistant W. W. DinwidDIE. During the next year two contact rings were added to the instrument for conveying the electric current from the pier to the eye-end of the telescope. These rings were designed by Mr. DiNWIDDIE, and constructed by KAHLER, of Washington, D. C. Each ring has five conductors, making it possible to have four independent circuits. The ring about the polar axis is attached to the right ascension clamp and turns with the axis, while its brush is fastened to the case of the worm screw. The other ring is fastened to the declination sleeve and its brush to the declination clamp ring.

The brushes have five conductors, separately insulated, to correspond to the number of conductors on the rings. Each conductor of the brush has four contact pins, and each pin is pressed against the ring by a separate spring, making it impossible for a dust particle on the ring to interrupt the circuit.

During the fiscal year ending June 30, I903, a new system of wiring was installed. A switchboard placed in the hall now controls all the lights in the building. From this board a circuit runs to a second switchboard on the elevating floor, which controls all the lights in the dome and on the instrument.

A I Io-volt commercial lighting circuit is now used for all illumination, thus doing away with the batteries formerly employed with the micrometer lamps. Standard lamps are used for illuminating the circles and micrometer in place of the special lamps previously used. The lamps for the hour circle are 28-volt and 2 candle-power; for the declination circle and the micrometer, 4-volt and 2 candlepower. Resistance coils for varying the brightness of both sets of threads of the micrometer are placed under the floor and controlled by rheostat switches on the switchboard.

This system of wiring, which gives entire satisfaction, was installed by Mr. Dinwiddie, who deserves the greatest credit for the many improvements to this instrument which have added greatly to its efficiency.

A bright-field illumination was devised and installed by Assistant C. W. FREDERICK in 1904 by reflecting light from a small 2 candle-power lamp to the inner surface of the objective by means of a prism within the telescope tube near the eyeend and just outside the cone of rays. The mechanical parts were later improved by Mr. Dinwiddie. This arrangement furnishes a good illumination for magnifying powers up to 400 , but when a higher magnifying power is used the field becomes too faint to see the threads well. 


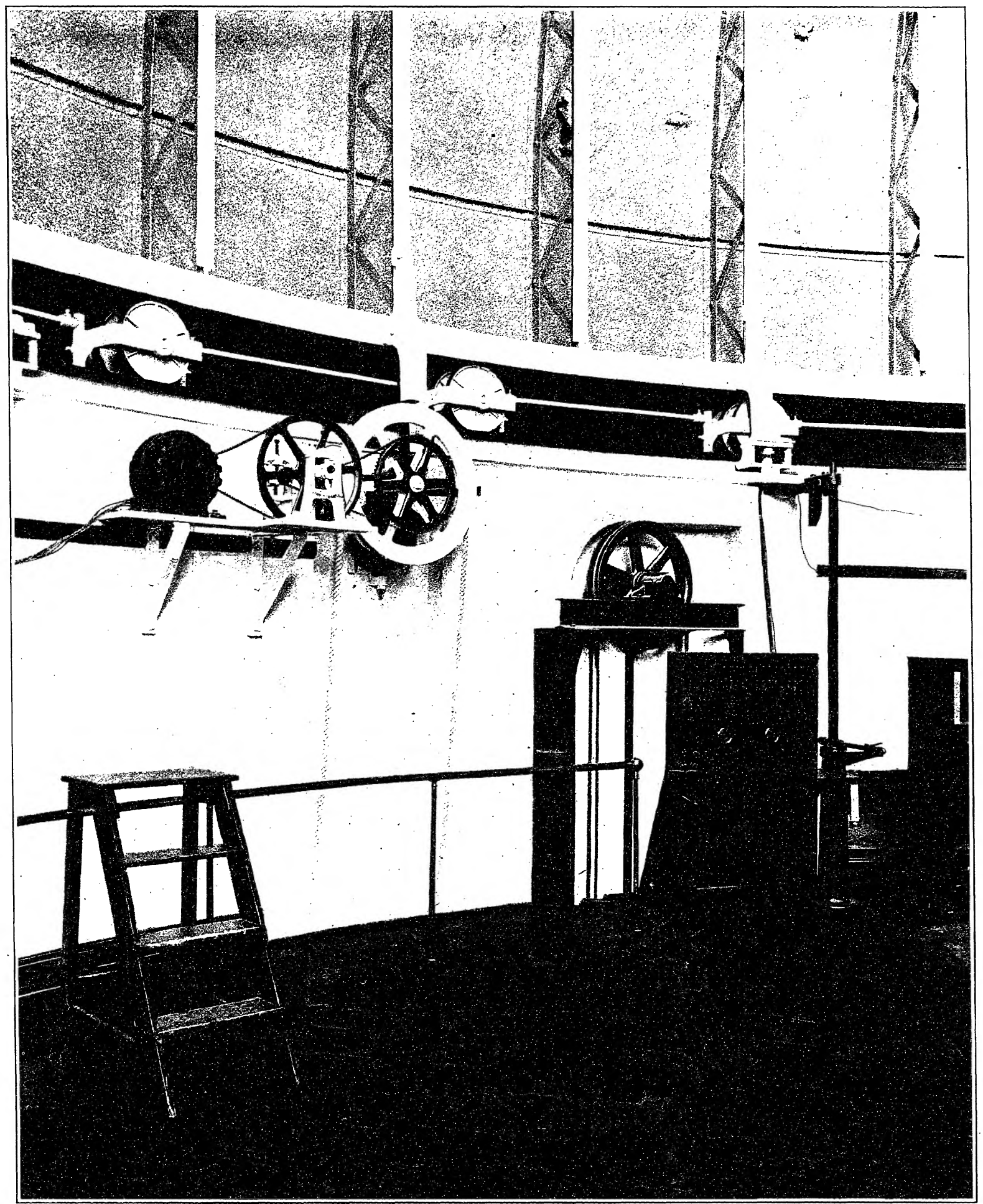

THE MOTOR FOR TURNING THE DOME AND THE SWITCHBOARD FOR CONTROLLING THE ILLUMINATION OF THE 26-INCH EQUATORIAL. 
The spectroscope.-The following description of the spectroscope (see PLATE VII) was taken partly from a report by Prof. S. J. Brown, U. S. N., in the annual report of the Superintendent for the fiscal year ending June 30, I899, and partly furnished by Assistant G. H. PETERs, who worked with Professor Brown on the instrument.

The spectroscope was constructed by the John A. Brashear Co., of Allegheny, $\mathrm{Pa}$, and is similar in all respects to that in use at the Allegheny Observatory and designed by its Director, Prof. J. E. KEELER. It is fitted with an adapter, the counterpart of that in use with the micrometer, so that the two are easily interchangeable. It can be used with a Rowland grating, of I4,438 lines to the inch. It has a single $60^{\circ}$ flint-glass prism, with minimum deviation apparatus and also a battery of three $60^{\circ}$ flint-glass prisms with automatic minimum deviation apparatus. An observing telescope with a micrometer for visual observations was supplied, and also photographic lenses with camera attachment. Comparison spectra apparatus is also a part of the equipment.

Spectroscopic work for determining the motion of certain stars in the line of sight was undertaken in November, r898.

The spectroscope was returned to BRASHEAR in March, I899, with instructions to substitute for the original prism box a new and much stronger one; to provide a HugGins slit with polished speculum metal jaws for the collimator; to provide two new photographic plate-holders, and to furnish a correcting lens, which would alter the focal curve of the equatorial objective in such a way as to shift the position of minimum focal distance from the FRAUnHOFER line $E=\lambda$ 5270 to the neighborhood of $\mathrm{H} r=\lambda$ 434I. These alterations and additions were successfully made and the spectroscope was returned in June, I899.

The work in the line of sight was never carried beyond the experimental stage, owing to inherent instrumental difficulties, and it was finally abandoned in September, 1900. It was found that, owing to the strong colors existing in the flint and crown glasses of the equatorial objective, the instrument was almost worthless for spectroscopic investigations by photographic methods in the blue region. The flint lens is of a decided yellow tint, while the crown lens is very green, producing a remarkable. degree of absorption in the region of the spectrum employed.

It was concluded that to overcome this difficulty of the absorption of the blue rays by the large objective it would be necessary to work near the red end of the spectrum, using ortho-chromatic plates. In view, however, of the decreased dispersion by prisms in this region, it was decided to be impracticable. The equatorial is also supplied with a direct-vision spectroscope, which can be attached to one side of the tube. This spectroscope was furnished with the instrument by its makers, The WARNER and SWASEy Company.

The camera.-During the fiscal year I9OI-O2 a 6-inch DALLMEYER portrait lens of 40 inches focal length, with a camera attachment, was mounted on the central section of the telescope tube opposite the declination axis. The camera was adapted for $4^{\prime \prime} \times 5^{\prime \prime}$ plates, and was used in the search for asteroids. In this work, of course the large telescope was used merely for following purposes and the arrangement was only temporary. The camera was removed from the instrument in May, I906, and mounted on a special telescope constructed for that purpose. 
The Clark Micrometer I.-This is the micrometer that was used continuously by Prof. Asaph Hali, U. S. N., from I 877 to I892. The screw of this micrometer was investigated by Prof. E. S. HoldEN, U. S. N., and the results are published in the Washington Astronomical Observations for I877, Volume XXIV, Appendix I. He concludes that "the screw of Micrometer I is practically perfect and requires no correction for inequalities in the whole revolutions or for periodic errors." The screw of this micrometer was again examined by Lieut. W. H. ALLEN, U. S. N., in I886 and by Professor HALI in I89I, and their results are published in the Washington Astronomical Observations for I888, Appendix I, page E 8 et seq. The corrections for periodic errors were, respectively,

$$
\begin{aligned}
& \varphi(u)=+\mathrm{o}^{\prime \prime} .0087 \sin u-\mathrm{o}^{\prime \prime} .0005 \cos u-\mathrm{o}^{\prime \prime} .0002 \sin 2 u+\mathrm{o}^{\prime \prime} .0052 \cos 2 u \ldots \text {. . ALLEN } \\
& \varphi(u)=+\mathrm{o}^{\prime \prime} .0016 \sin u+\mathrm{o}^{\prime \prime} .0019 \cos u-\mathrm{o}^{\prime \prime} .0027 \sin 2 u-\mathrm{o}^{\prime \prime} .0016 \cos 2 u \ldots \text {. . HALL }
\end{aligned}
$$

The illumination for this micrometer was furnished by a hand lamp which threw a red light on the wires through an opening in the end of the micrometer box. There were but four wires in the micrometer, one fixed longitudinal wire, and at right angles to this one movable wire and two fixed wires, usually designated as Wire $A$ and Wire B. The coincidence of the movable wire with Wire A was about 64 revolutions, and with Wire $\mathrm{B} 93$ revolutions.

This micrometer was in use until March, I900, when it was replaced by Micrometer II. The value of one revolution of the screw of Micrometer I used in reducing all the observations made with it and which are published in this volume is

$$
R=9^{\prime \prime} \cdot 9360
$$

This is the value determined by Prof. AsapH HALL from his later measurements of the differences in declination of certain well-known stars and published in the Washington Astronomical Observations for I89I, page XLVII.

The Clark Micrometer II.-This micrometer was made by ALVAN CraRk and Sons. The screw was investigated by Professor HoLDEN in the same manner as that of Micrometer I, and the results are published in the Washington Astronomical Observations for I877, Volume XXIV, Appendix I. Again he concludes that "the screw of Micrometer II between o and 8o revolutions is practically perfect and requires no correction for inequalities of whole revolutions nor for periodic error."

This micrometer was fitted with an electric illumination by The WARNER and SwASEY Company in December, I899, and was placed on the instrument in March, I900. It has been used continuously to the present time.

Micrometer II has five fixed longitudinal wires placed parallel to each other at intervals of about 90". These threads are used for taking transits when differences of right ascension are measured by the method of transits. The middle thread of the five has usually been used in measuring position angles. At right angles to this set of threads is one fixed thread and three movable threads rigorously parallel to this fixed thread and carried on a slide attached to the micrometer screw. These threads are numbered I, II, and III in order from the micrometer head. The intervals between these threads are approximately I-II $=3 \mathrm{I} 2^{\prime \prime}, I I-I I I=3 I 2^{\prime \prime}$, and I-III $=624^{\prime \prime}$. The coincidences of the three threads with the fixed thread vary with the temperature, but are approximately 68.500 revolutions for I, I00.000 revolutions for II, and I 3 I.400 revolutions for III. 


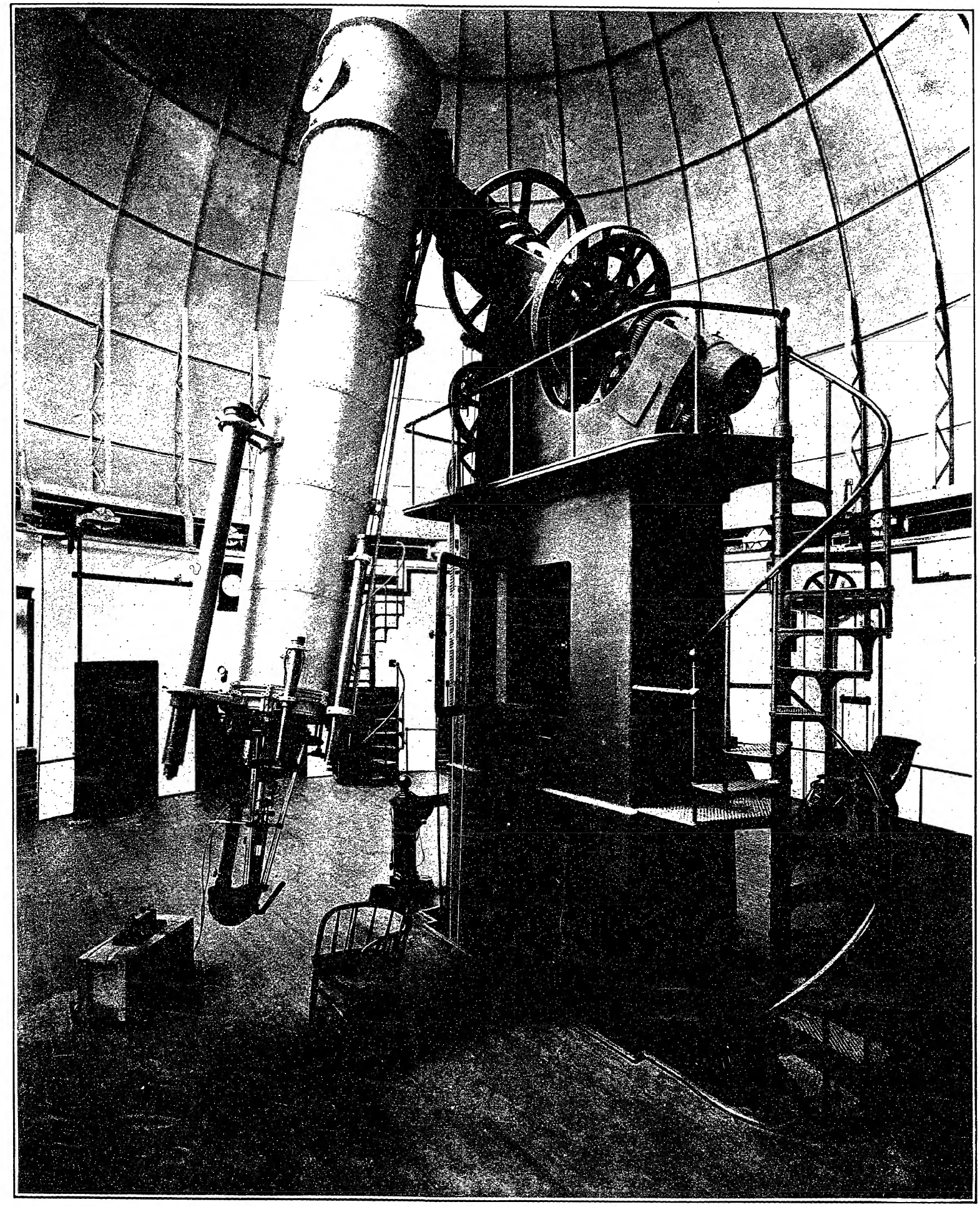

THE 26-INCH EQUATORIAL WITH SPĖCTROSCOPE ATTACHED. 
The illumination at present is as follows: One lamp at the end of the micrometer box illuminates the movable wires and the fixed wire parallel to them, directly and by reflection from a cylindrical mirror on the opposite side. The five longitudinal wires are illuminated by two lamps on a collar having a slight rotary motion. These lamps are placed at an angle of about $45^{\circ}$ to the tube of the telescope and are $180^{\circ}$ apart. The lamps employed are 2 candle-power.

In April, I908, the screw of this micrometer was again investigated for inequalities by Prof. AsAPH HALI, jr., and Assistant Astronomer J. C. HAmmond with the Ruled Glass Scale Comparator which is described in the Washington Astronomical Observations for I877, Volume XXIV, Appendix I, page I2 et seq. This comparator has a slide rest bearing a micrometer eyepiece denoted in the following as Micrometer A.

The method of procedure was as follows: Micrometer II was placed on the comparator so that its screw was parallel to the motion of this slide rest, and Micrometer A was focussed on the threads of Micrometer II. The latter was then set at a whole revolution and several settings of $A$ were made on a wire of II. This movable wire of II was then moved by a quarter revolution and more settings made with $A$. This was continued throughout a whole revolution of II and back to the starting point. Then Micrometer II was set at the next whole revolution and the slide rest moved forward, care being exercised that Micrometer A should read about the same for the beginning of each revolution of II. In this way each revolution of Micrometer II was measured with the same part of the screw of Micrometer A. This was done for each revolution from 70 to $\mathrm{I} 3 \mathrm{O}$.

Then from 95 to Io3 revolutions, each quarter revolution of Micrometer II was measured with the same part of $A$. The first set of measures would show the inequalities in the whole revolutions of II if any existed; the second set would determine the periodic errors. The results are given in the following tables. One revolution of Micrometer A corresponds to $3^{\prime \prime}$.04.9.

TABLE I.-Showing Inequalities in the Whole Revolutions.

\begin{tabular}{|c|c|c|c|c|c|c|c|c|c|c|c|}
\hline \multicolumn{2}{|c|}{ Micrometer } & \multirow{2}{*}{$\begin{array}{c}\text { Residuals } \\
\text { from } \\
\text { Mean. }\end{array}$} & \multicolumn{2}{|c|}{ Micrometer } & \multirow{2}{*}{$\begin{array}{c}\text { Residuals } \\
\text { from } \\
\text { Mean. }\end{array}$} & \multicolumn{2}{|c|}{ Micrometer } & \multirow{2}{*}{$\begin{array}{c}\text { Residuals } \\
\text { from } \\
\text { Mean. }\end{array}$} & \multicolumn{2}{|c|}{ Micrometer } & \multirow{2}{*}{$\begin{array}{l}\text { Residuals } \\
\text { from } \\
\text { Mean. }\end{array}$} \\
\hline II. & A. & & II. & A. & & II. & A. & & II. & A. & \\
\hline rev. & rev. & $\prime \prime$ & rev. & rev. & $\prime \prime$ & rev. & rev. & '" & rev. & rev. & " \\
\hline $7 \mathrm{O}-7 \mathrm{I}$ & $3 \cdot 249$ & +0.024 & $85-86$ & $3.26 I$ & -0.012 & IOO-IOI & 3.269 & -0.037 & I I $5-1$ I 6 & $3.26 \mathrm{I}$ & -0.012 \\
\hline $71-72$ & 3.256 & +0.003 & $86-87$ & $3 \cdot 25^{8}$ & -0.003 & IOI-102 & $3 \cdot 267$ & -0.030 & I I 6-II 7 & 3.267 & -0.030 \\
\hline $72-73$ & 3.276 & $-0.05^{8}$ & $87-88$ & 3.263 & -0.018 & $\mathrm{ro2}-\mathrm{rO} 3$ & $3 \cdot 268$ & -0.034 & I I $7-1$ I 8 & 3.260 & -0.009 \\
\hline $73-74$ & 3.268 & -0.034 & $88-89$ & 3.249 & to. 024 & IO3-IO4 & $3 \cdot 264$ & -0.021 & II $8-$ I I9 & $3.26 \mathrm{I}$ & -0.012 \\
\hline $74-75$ & $3 \cdot 254$ & +o. 009 & $89-90$ & $3 \cdot 252$ & +o.015 & $104-105$ & 3.267 & -0.030 & II $19-120$ & 3.254 & +o. 009 \\
\hline $75-76$ & 3.254 & +0.009 & $90-9 \mathrm{I}$ & 3.260 & -0.009 & 105-I06 & 3.260 & -0.009 & $120-12 I$ & 3.275 & -0.055 \\
\hline $7^{6-77}$ & 3.264 & -0.021 & $9 x-92$ & 3.254 & +o. 009 & 106-107 & $3 \cdot 257$ & 0.000 & $121-122$ & 3.260 & -0.009 \\
\hline $77-78$ & 3.234 & +0.070 & $92-93$ & $3 \cdot 24 \mathrm{I}$ & +o. 049 & $107-108$ & 3. 264 & -0.021 & $122-123$ & $3 \cdot 258$ & -0.003 \\
\hline $78-79$ & 3.230 & +0.082 & $93-94$ & 3.259 & -0.006 & $108-109$ & 3.260 & -0.009 & $123-124$ & 3.238 & +o. $05^{8}$ \\
\hline $79-80$ & 3.243 & +o. 043 & $94-95$ & 3.255 & +0.006 & IO9-I IO & 3.262 & -0.015 & $124-125$ & $3.25 \mathrm{I}$ & +o.018 \\
\hline $80-8 I$ & 3. 253 & +o.01 2 & $95-96$ & 3.256 & +0.003 & IIO-III & 3.253 & +o.012 & I25-I 26 & $3 \cdot 25 \mathrm{I}$ & +o. 018 \\
\hline $8 I-82$ & 3.263 & -0.018 & $96-97$ & 3. 244 & to. 040 & $\operatorname{II} I-I I 2$ & 3.250 & +0.021 & I $26-127$ & 3.250 & +0.021 \\
\hline $82-83$ & 3. 239 & +0.055 & $97-98$ & 3.260 & -0.009 & I I $2-I$ I 3 & 3.260 & -0.009 & $127-128$ & 3.246 & +o. 034 \\
\hline $83-84$ & 3.248 & +o. 034 & $98-99$ & 3.255 & +0.006 & II $3-114$ & 3.262 & -0.015 & $128-129$ & 3.250 & +0.021 \\
\hline $84-85$ & 3. 259 & -0.006 & $99-100$ & 3.274 & -0.052 & I I 4 I I 5 & 3.258 & -0.001 & I 29-I30 & 3.260 & -0.009 \\
\hline
\end{tabular}


These residuals are small and are probably due to accidental errors in setting Micrometer A. The largest residual, $\mathrm{O}^{\prime \prime} .082$, is less than the accidental errors in the observations of any night.

TABLE II.--Showing Inequalities in the Quarter Revolutions as Measured by Different Parts of Micrometer A.

\begin{tabular}{|c|c|c|c|c|c|c|c|c|}
\hline \multirow{2}{*}{$\begin{array}{l}\text { Micrometer } \\
\text { II. }\end{array}$} & \multirow{2}{*}{$\begin{array}{c}\text { First } \\
\text { Quarter. }\end{array}$} & \multirow{2}{*}{$\begin{array}{l}\text { Second } \\
\text { Quarter. }\end{array}$} & \multirow{2}{*}{$\begin{array}{c}\text { Third } \\
\text { Quarter. }\end{array}$} & \multirow{2}{*}{$\begin{array}{l}\text { Fourth } \\
\text { Quarter. }\end{array}$} & \multicolumn{4}{|c|}{ Residuals from Mean. } \\
\hline & & & & & $\begin{array}{c}\text { First } \\
\text { Quarter. }\end{array}$ & $\begin{array}{l}\text { Second } \\
\text { Quarter. }\end{array}$ & $\begin{array}{c}\text { Third } \\
\text { Quarter. }\end{array}$ & $\begin{array}{l}\text { Fourth } \\
\text { Quarter. }\end{array}$ \\
\hline $\begin{array}{l}\text { rev. } \\
70-71\end{array}$ & $\begin{array}{l}\text { rev. } \\
\text { 0. } 814\end{array}$ & $\begin{array}{l}\text { rev. } \\
\text { o. } 822\end{array}$ & $\begin{array}{l}\text { rev. } \\
\text { o. } 800\end{array}$ & $\begin{array}{l}\text { rev } \\
0.813\end{array}$ & $\begin{array}{c}\prime \prime \\
\text { o. } 000\end{array}$ & $\begin{array}{c}\prime \prime \\
-0.024\end{array}$ & $\begin{array}{c}\prime \prime \\
+0.043\end{array}$ & $\begin{array}{c}\prime \prime \\
+0.003\end{array}$ \\
\hline $71-72$ & 0.818 & 0.809 & o. $83 \mathrm{I}$ & o. 798 & -0.012 & to.015. & -0.052 & +o. 049 \\
\hline $72-73$ & o. $8 \mathrm{I} 7$ & 0.817 & o. 836 & o. 806 & -0.009 & -0.009 & -0.067 & +o. 024 \\
\hline $73-74$ & o. 8 ro & o. 832 & o. $8 \mathrm{II}$ & 0.815 & -0.012 & -0.055 & +o. 009 & -0.003 \\
\hline $74-75$ & o. 817 & o. $8 \mathrm{II}$ & o. 826 & o. 800 & -0.009 & +0.009 & -0.037 & +o. 043 \\
\hline $75-76$ & 0.798 & 0.810 & o. 824 & 0.822 & to. 049 & +o.012 & -0.030 & -0.024 \\
\hline $76-77$ & o. 808 & 0.810 & o. 830 & 0.816 & to.018 & +0.012 & -0.049 & -0.006 \\
\hline $77-78$ & o. 795 & 0.827 & o. 824 & o. 788 & +0.058 & -0.040 & -0.030 & +o. 079 \\
\hline $78-79$ & o. $79 \mathrm{I}$ & o. 798 & o. 833 & 0.808 & +0.070 & +o. 049 & -0.058 & +o. o1 8 \\
\hline $79-80$ & 0. 806 & 0.817 & 0.816 & o. 804 & +0.024 & -0.009 & -0.006 & +0.030 \\
\hline $80-8 I$ & 0.814 & 0.815 & 0.813 & $0.8 \mathrm{II}$ & o. 000 & -0.003 & +0.003 & +o. 009 \\
\hline $8 I-82$ & o. 806 & o. 806 & o. 830 & $0.82 \mathrm{I}$ & +0.024 & +0.024 & -0.049 & -0.021 \\
\hline $82-83$ & o. 800 & 0.814 & o. 823 & 0.802 & to. 043 & o. 000 & -0.027 & +0.037 \\
\hline $83-84$ & o. 804 & 0.820 & o. 826 & o. 798 & +0.030 & -0.018 & -0.037 & +o. 049 \\
\hline $84-85$ & o. 813 & $0.82 \mathrm{I}$ & o. 812 & 0.813 & +0.003 & -0.021 & +0.006 & +o. 003 \\
\hline $85-86$ & o. $8 \mathrm{II}$ & 0.816 & o. 815 & o. 819 & +o. 009 & -0.006 & -0.003 & -0.015 \\
\hline $86-87$ & o. 813 & o. 820 & o. 806 & 0.819 & +0.003 & -0.018 & +0.024 & -0.015 \\
\hline $87-88$ & o. 814 & o. 820 & o. 812 & 0.817 & o. 000 & -0.018 & +0.006 & -0.009 \\
\hline $88-89$ & o. 803 & o. $82 \mathrm{I}$ & o. 812 & 0.813 & to. 034 & $-0.02 \mathrm{I}$ & +0.006 & +0.003 \\
\hline $89-90$ & o. 812 & o. 816 & o. $8 \mathrm{I} 4$ & o. 810 & to. 006 & -0.006 & o. 000 & +o. 012 \\
\hline $90-91$ & o. 812 & o. 824 & o. 810 & o. 814 & to. 006 & -0.030 & +o.012 & 0.000 \\
\hline $91-92$ & o. 807 & 0.812 & o. 822 & o. 813 & +0.021 & +o. 004 & -0.024 & +0.003 \\
\hline $92-93$ & o. 791 & o. 817 & o. 822 & o. $8 \mathrm{I}$ I & to. 070 & -o. 009 & -0.024 & +o. 009 \\
\hline $93-94$ & 0.813 & o. $83 \mathrm{I}$ & o. 812 & o. 803 & +o. 003 & -0.052 & +0.006 & +o. 034 \\
\hline $94-95$ & o. 808 & o. 818 & o. 822 & o. 807 & +o. or 8 & -0.012 & -0.024 & $+0.02 \mathrm{I}$ \\
\hline $95-96$ & o. 805 & o. 806 & o. 832 & o. $8 \mathrm{r} 3$ & +0.027 & +o. 024 & -0.055 & +o. 003 \\
\hline $96-97$ & o. 802 & o. 814 & o. 824 & o. 804 & +o. 037 & 0.000 & -0.030 & to. 030 \\
\hline $97-98$ & o. 814 & 0.811 & o. 829 & o. 806 & o. 000 & +0.009 & -0.046 & +o. 024 \\
\hline $98-99$ & o. 808 & 0.819 & o. 805 & o. 823 & to. or 8 & -0.015 & +0.027 & -0.027 \\
\hline $99-100$ & o. 822 & o. 806 & o. 830 & o. $8 \mathrm{I} 6$ & -0.024 & +0.024 & -0.049 & -0.006 \\
\hline IOO-IOI & o. 815 & o. 814 & o. 822 & o. 818. & -0.003 & 0.000 & -0.024 & -0.012 \\
\hline $101-102$ & o. 820 & o. 814 & o. 826 & o. $807^{\circ}$ & -0.018 & o. 000 & -0.037 & -0.021 \\
\hline $102-103$ & 0.816 & $0.82 \mathrm{I}$ & o. 823 & o. 808 & -0.006 & $-0.02 \mathrm{I}$ & -0.027 & +o. o1 8 \\
\hline $103-104$ & 0.812 & $0.8 \mathrm{II}$ & o. 819 & o. 822 & +o. 006 & +o. 009 & -0.015 & -0. 024 \\
\hline $104-105$ & o. 818 & o. 806 & o. 829 & o. $8 \mathrm{I} 4$ & -0.012 & +0.024 & -0.046 & 0.000 \\
\hline $105-106$ & o. 806 & o. 820 & o. 827 & o. 807 & +0.024 & -0.018 & -0.040 & +0.021 \\
\hline $106-107$ & 0.802 & 0.822 & o. 824 & o. 809 & to. 037 & -0.024 & -0.030 & +o. or' 5 \\
\hline $107-108$ & 0.818 & o. 805 & o. $83 \mathrm{I}$ & o. 810 & -0.012 & +0.027 & $-0.05^{2}$ & +o. 012 \\
\hline $108-109$ & 0.800 & o. 818 & o. 827 & o. 815 & +0.043 & -0.012 & -0.040 & -0.003 \\
\hline rog-rio & 0.803 & o. 819 & o. 827 & o. 813 & +o. 034 & -0.015 & -0.040 & to. 003 \\
\hline I IO-I I I & 0.808 & o. 829 & o. 808 & o. 808 & to. 018 & -0.045 & +o.01 8 & to. o1 8 \\
\hline I I I I I 2 & o. 808 & o. 824 & o. 810 & o. 808 & to. 018 & -0.030 & +o. 012 & to. o1 8 \\
\hline
\end{tabular}


TABLE II.-Showing Inequalities in the Quarter Revolutions as Measured by Different Parts of Micrometer A-Continued.

\begin{tabular}{|c|c|c|c|c|c|c|c|c|}
\hline \multirow{2}{*}{$\begin{array}{l}\text { Micrometer } \\
\text { II. }\end{array}$} & \multirow{2}{*}{$\begin{array}{c}\text { First } \\
\text { Quarter. }\end{array}$} & \multirow{2}{*}{$\begin{array}{l}\text { Second } \\
\text { Quarter. }\end{array}$} & \multirow{2}{*}{$\begin{array}{c}\text { Third } \\
\text { Quarter. }\end{array}$} & \multirow{2}{*}{$\begin{array}{l}\text { Fourth } \\
\text { Quarter. }\end{array}$} & \multicolumn{4}{|c|}{ Residuals from Mean. } \\
\hline & & & & & $\begin{array}{c}\text { First } \\
\text { Quarter. }\end{array}$ & $\begin{array}{l}\text { Second } \\
\text { Quarter. }\end{array}$ & $\begin{array}{c}\text { Third } \\
\text { Quarter. }\end{array}$ & $\begin{array}{l}\text { Fourth } \\
\text { Quarter. }\end{array}$ \\
\hline $\begin{array}{c}\text { rev. } \\
\text { I I } 2-1 \text { I } 3\end{array}$ & $\begin{array}{l}\text { rev. } \\
\text { o. } 809\end{array}$ & $\begin{array}{l}\text { rev. } \\
\text { o. } 803\end{array}$ & $\begin{array}{c}\text { rev. } \\
\text { o. } 830\end{array}$ & $\begin{array}{c}\text { rev. } \\
\text { o. } 818\end{array}$ & $\begin{array}{c}\prime \prime \\
+0.015\end{array}$ & $\begin{array}{c}\prime \prime \\
+0.034\end{array}$ & $\begin{array}{c}\prime \prime \\
-0.049\end{array}$ & $\begin{array}{c}\prime \prime \\
-0.012\end{array}$ \\
\hline II $3-$ I I 4 & o. 805 & o. $82 \mathrm{I}$ & o. $82 \mathrm{I}$ & 0.8 I 5 & +0.027 & $-0.02 \mathrm{I}$ & $-0.02 \mathrm{I}$ & -0.003 \\
\hline I I 4-I I 5 & 0. 8 I I & o. 808 & o. 833 & o. 806 & +o. 009 & +o. o1 8 & $-0.05^{8}$ & +o. 024 \\
\hline I I 5-I I 6 & o. $8 \mathrm{ro}$ & o. 8 I 3 & o. 824 & o. 8 I 4 & +o.012 & +0.003 & -0.030 & o. OOo \\
\hline I I6-I I 7 & o. 812 & o. 8 r 5 & o. $83 \mathrm{I}$ & o. 809 & +o. 006 & -0.003 & -0.052 & +o. $\mathrm{OI}_{5}$ \\
\hline I I $7-1$ I 8 & o. 800 & o. 828 & o. 8 I 7 & o. 8 I 5 & +o. 043 & -0.043 & -0.009 & -0.003 \\
\hline I $18-119$ & $0.8 \mathrm{II}$ & o. 810 & o. 828 & $0.8 \mathrm{I} 2$ & +o. 009 & +o. Or 2 & -0.043 & +o. 006 \\
\hline I 19-1 20 & o. 803 & o. 825 & o. 8 I 8 & o. 808 & +o. 034 & -0.034 & -0.012 & +o. ог 8 \\
\hline $\mathrm{I} 2 \mathrm{O}-\mathrm{I} 2 \mathrm{I}$ & $0.8 \mathrm{I} 3$ & o. 8 I 8 & o. 826 & 0. 8 I 8 & +o. 003 & -0.012 & -0.037 & -0.012 \\
\hline $121-122$ & o. 808 & o. $8 \mathrm{II}$ & o. 829 & 0.812 & +o.01 8 & +o. 009 & -0.046 & +o. 006 \\
\hline $122-123$ & 0.806 & o. 823 & o. 819 & o. 810 & +0.024 & -0.027 & -0.015 & +o. 012 \\
\hline $123-124$ & 0.809 & o. 813 & o. 808 & o. 808 & +o. OI 5 & +0.003 & +o.01 8 & +o. ог 8 \\
\hline $124-125$ & 0.807 & o. 8 I 6 & o. 822 & 0.806 & $+0.02 \mathrm{I}$ & -0.004 & -0.024 & +0.024 \\
\hline $125-126$ & o. 794 & o. 8 I 6 & 0. 822 & o. 819 & +o. $06 \mathrm{r}$ & -0.006 & -0.024 & -O.OI5 \\
\hline I $26-127$ & 0.804 & o. 8 r 8 & 0. 8 I 8 & o. 810 & +o.030 & -0.012 & -0.012 & +o. OI 2 \\
\hline $127-128$ & o. 795 & o. 823 & 0.813 & o. 815 & +o. $05^{8}$ & -0.027 & +o. 003 & -0.003 \\
\hline I $28-$ I 29 & o. 804 & o. 8 I 8 & o. 822 & o. 806 & +o. 030 & -0.012 & -0.024 & +0.024 \\
\hline I $29-$ I 30 & 0.823 & o. 808 & o. 814 & o. 8 I $_{5}$ & -0.027 & 十o.018 & o. 000 & -0.003 \\
\hline
\end{tabular}

The preponderance of positive signs in the residuals for the first quarter and of negative signs in those of the third quarter seems to show that there is a small periodic error either in the screw of Micrometer II or in that of Micrometer A.

The mean of the residuals for the first quarter is $\ldots \ldots \ldots \ldots \ldots \ldots+o^{\prime \prime}$.or 70

The mean of the residuals for the second quarter is $\ldots \ldots \ldots \ldots \ldots \ldots-\mathrm{o}^{\prime \prime} .0065$

The mean of the residuals for the third quarter is . . . . . . . . .

The mean of the residuals for the fourth quarter is . . . . . . . . . . $+o^{\prime \prime} .0085$

These residuals give the formula for periodic errors: $\varphi(u)=-\mathrm{o}^{\prime \prime} .0060 \cos u+\mathrm{o}^{\prime \prime} .0135 \sin u+\mathrm{o}^{\prime \prime} .0008 \cos 2 u$.

TABLE III.-Showing Inequalities in the Quarter Revolutions from 95 Revolutions to to3 Revolutions as Measured by the same Part of Micrometer A.

\begin{tabular}{|c|c|c|c|c||c|c|c|c|}
\hline $\begin{array}{c}\text { Micrometer } \\
\text { II. }\end{array}$ & $\begin{array}{c}\text { First } \\
\text { Quarter. }\end{array}$ & $\begin{array}{c}\text { Second } \\
\text { Quarter. }\end{array}$ & $\begin{array}{c}\text { Third } \\
\text { Quarter. }\end{array}$ & $\begin{array}{c}\text { Fourth } \\
\text { Quarter. }\end{array}$ & $\begin{array}{c}\text { First } \\
\text { Quarter. }\end{array}$ & $\begin{array}{c}\text { Second } \\
\text { Quarter. }\end{array}$ & $\begin{array}{c}\text { Third } \\
\text { Quarter. }\end{array}$ & $\begin{array}{c}\text { Fourth } \\
\text { Quarter. }\end{array}$ \\
\hline rev. & rev. & rev. & rev. & rev. & $\prime \prime$ & $\prime \prime$ & $\prime \prime$ & $\prime \prime$ \\
$95-96$ & 0.801 & 0.812 & 0.800 & 0.817 & +0.021 & -0.012 & +0.024 & -0.027 \\
$96-97$ & 0.793 & 0.804 & 0.804 & 0.811 & +0.046 & +0.012 & +0.012 & -0.009 \\
$97-98$ & 0.807 & 0.810 & 0.806 & 0.813 & +0.003 & -0.006 & +0.006 & -0.015 \\
$98-99$ & 0.800 & 0.804 & 0.805 & 0.802 & +0.024 & +0.012 & +0.009 & +0.018 \\
$99-100$ & 0.806 & 0.811 & 0.809 & 0.815 & +0.006 & -0.009 & -0.003 & -0.021 \\
100-101 & 0.813 & 0.807 & 0.805 & 0.811 & -0.015 & +0.003 & +0.009 & -0.009 \\
101-102 & 0.809 & 0.814 & 0.815 & 0.817 & -0.003 & -0.018 & -0.021 & -0.027 \\
$102-103$ & 0.815 & 0.805 & 0.812 & 0.813 & -0.021 & +0.009 & -0.012 & -0.015 \\
\hline
\end{tabular}


These residuals show that the periodic error in the screw of Micrometer II, if any exists, is inappreciable.

The mean of the residuals for the first quarter is $\ldots \ldots \ldots \ldots \ldots \ldots+\mathrm{o}^{\prime \prime} .0076$

The mean of the residuals for the second quarter is $\ldots \ldots \ldots \ldots \ldots \ldots-\mathrm{o}^{\prime \prime}$.oor I

The mean of the residuals for the third quarter is $\ldots \ldots \ldots \ldots \ldots \ldots+\mathrm{o}^{\prime \prime}$.oozo

The mean of the residuals for the fourth quarter is $\ldots \ldots \ldots \ldots \ldots \ldots-\mathrm{o}^{\prime \prime}$.or $3 \mathrm{I}$

They give as the formula for periodic errors:

$$
\varphi(u)=-\mathrm{o}^{\prime \prime} .0042 \cos u-\mathrm{o}^{\prime \prime} .00 \mathrm{r} 8 \sin u-\mathrm{o}^{\prime \prime} .003 \mathrm{I} \cos 2 u .
$$

The screw of Micrometer II shows no deterioration from wear but remains a very excellent one in all respects.

The value of one revolution of the screw of Micrometer II with which all the observations, made with it and published in this volume, have been reduced is one determined by Prof. T. J. J. SEE, U. S. N., from observations of arcs in the Pleiades and in Perseus. The results of his measures have been published in the introduction to his observations of Eros in I900-I9or. (See Publications of the United States Naval Observatory, Second Series, Volume III, Part I, page Avi et seq.) This value is

$$
R=9^{\prime \prime} .9328-0^{\prime \prime} .000055\left(T-28^{\circ} F \text {. }\right)
$$

In January and February, I906, some measures of four arcs in the Pleiades were made by Mr. HAMmond, with the following results. The range of temperature during these observations was not sufficiently. large to determine a temperature coefficient with any degree of accuracy and therefore this coefficient is omitted. The mean temperature was $T=39^{\circ}$ Fahrenheit. The focus was changed by 0.05 inch during the measures, the reading of the focal scale being $\mathrm{I} .32$ inches at the beginning and 1.27 inches at the end. A decrease of 0.05 inch in focal length of the instrument corresponds to an increase of $\mathrm{O}^{\prime \prime} . \mathrm{OOI} 3$ in the value of one revolution of the screw.

Focal scale......... I. 32 inches.

\begin{tabular}{|r|c|c|}
\hline \multicolumn{1}{|c|}{ Arc. } & $\mathrm{R}$ & $\begin{array}{c}\text { Number } \\
\text { of Nights. }\end{array}$ \\
\hline Atlas-Pleione...... & $9.9316 \pm 0.0013$ & 4 \\
Alcyone-Bessel 24... & $9.9331 \pm 0.0002$ & 2 \\
Maia-Asterope...... & $9.9310 \pm 0.0007$ & 2 \\
Electra-Celaeno..... & $9.9340 \pm 0.0010$ & 2 \\
\hline Mean........ & 9.9324 (equal & \\
\hline & weights). & \\
\hline
\end{tabular}

If we assign equal weight to the different determinations, we have as the value of one revolution of the screw
Focal scale........ I. 27 inches.

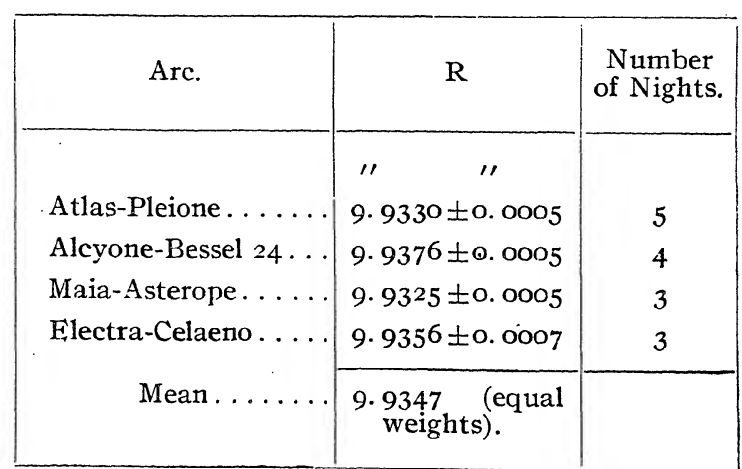

$R=9^{\prime \prime} .9336$ at a temperature of $39^{\circ}$ Fahrenheit. 
This is in good agreement with the value determined by Professor SEE for this temperature, viz:

$$
R=9^{\prime \prime} \cdot 9322
$$

The Warner and Swasey micrometer. - This micrometer was made by The WARnER and SWASEy Company at the same time as the new mounting for the instrument. The threads are arranged similarly to those in the CLARK Micrometer II, except that it has only one fixed longitudinal wire. It is therefore not well adapted for measuring differences in right ascension by the method of transits. The wires are illuminated by a small electric lamp opposite the micrometer head. The value of one revolution of the screw has never been accurately determined, but is approximately $\mathrm{IO}^{\prime \prime} \cdot 5$. The coincidence of the middle movable thread with the fixed thread occurs at about 50.7 revolutions.

In March, 1908, the screw of this micrometer was investigated for periodic and progressive errors by Mr. HAMmond in substantially the same way as was that of Crark Micrometer II. The results are exhibited in TABLES IV, V, and VI.

TABLE IV.--Showing Inequalities in the Whole Revolutions.

\begin{tabular}{|c|c|c|c|c|c|c|c|c|c|c|c|}
\hline \multicolumn{2}{|c|}{ Micrometer } & \multirow{2}{*}{$\begin{array}{l}\text { Residu- } \\
\text { als from } \\
\text { Mean. }\end{array}$} & \multicolumn{2}{|c|}{ Micrometer } & \multirow{2}{*}{$\begin{array}{l}\text { Residu- } \\
\text { als from } \\
\text { Mean. }\end{array}$} & \multicolumn{2}{|c|}{ Micrometer } & \multirow{2}{*}{$\begin{array}{l}\text { Residu- } \\
\text { als from } \\
\text { Mean. }\end{array}$} & \multicolumn{2}{|c|}{ Micrometer } & \multirow{2}{*}{$\begin{array}{l}\text { Residu- } \\
\text { als from } \\
\text { Mean. }\end{array}$} \\
\hline W. and S. & A. & & W.and S. & A. & & W.and S. & A. & & W.and S. & A. & \\
\hline rev. & rev. & " & rev. & rev. & " & rev. & rev. & "' & res. & rev. & $" \prime$ \\
\hline $2 \dot{z}-23$ & 3. 182 & -o.010 & $37-38$ & $3 \cdot 45^{2}$ & -0.015 & $52-53$ & 3.447 & o. 000 & $67-68$ & 3.447 & 0.000 \\
\hline $23-24$ & 3. $19^{8}$ & -0.087 & $3^{8-39}$ & $3.44 \mathrm{I}$ & +o. 018 & $53-54$ & $3 \cdot 442$ & +o.015 & $68-69$ & $3.45 \mathrm{I}$ & -0.012 \\
\hline $24-25$ & 3. 195 & -0.073 & $39-40$ & 3.444 & +o. 009 & $54-55$ & 3.450 & -0.009 . & $69-70$ & $3 \cdot 44 \mathrm{I}$ & +o.018 \\
\hline $25^{-26}$ & 3. I 88 & -0.039 & $40 \sim 4 \mathrm{I}$ & 3.470 & $-0.07 \sigma$ & $55^{-56}$ & 3.452 & -0.015 & $70 \sim 71$ & $3 \cdot 447$ & 0.000 \\
\hline $26-27$ & 3. 194 & -0.068 & $4 I-42$ & $3 \cdot 46 \mathrm{I}$ & -0.043 & $56-57$ & 3: 449 & -0.006 & $71 \sim 72$ & $3.45^{\mathrm{I}}$ & -0.012 \\
\hline $27-28$ & 3. 192 & -0.058 & $42-43$ & $3 \cdot 445$ & +0.006 & $57-58$ & 3.455 & -0.025 & $7^{2-73}$ & $3 \cdot 439$ & +0.025 \\
\hline $28-29$ & 3. 188 & -0.039 & $43-44$ & 3.453 & -0.018 & $5^{8-59}$ & $3 \cdot 447$ & o. 000 & $73-74$ & $3 \cdot 448$ & -0.003 \\
\hline $29-30$ & 3. 180 & o. 000 & $44-45$ & $3 \cdot 45^{8}$ & -0.034 & $59-60$ & $3 \cdot 44^{2}$ & +o. OI 5 & $74-75$ & $3 \cdot 444$ & +o. 009 \\
\hline $30-31$ & 3.163 & +0.082 & $45-46$ & $3 \cdot 45^{8}$ & -0.034 & $6 o-61$ & $3 \cdot 437$ & +0.031 & $75-76$ & 3.434 & +0.040 \\
\hline $31-32$ & 3.161 & +0.092 & $46-47$ & $3 \cdot 448$ & -0.003 & $6 I-62$ & $3 \cdot 444$ & +o. 009 & $7^{6-77}$ & 3.425 & +0.067 \\
\hline $32-33$ & 3. 162 & +0.087 & $47-48$ & 3.445 & +o. 006 & $62-63$ & $3 \cdot 454$ & $-0.02 \mathrm{I}$ & $77-78$ & $3 \cdot 443$ & +0.012 \\
\hline $33-34$ & 3. $15 \mathrm{I}$ & to. I 40 & $48-49$ & $3 \cdot 460$ & -0.040 & $63-64$ & 3.440 & +0.021 & $78-79$ & $3 \cdot 437$ & +0.031 \\
\hline $34-35$ & $* 3.445$ & +o. 006 & $49-5^{\circ}$ & 3.455 & -0.025 & $64-65$ & 3.443 & to. or 2 & $79-80$ & 3.453 & -0.018 \\
\hline $35-36$ & $3 \cdot 45^{\circ}$ & -0.009 & $5^{\mathrm{O}-5 \mathrm{I}}$ & 3.437 & +0.031 & $65-66$ & $3 \cdot 444$ & +o:0og & & & \\
\hline $36-37$ & $3 \cdot 445$ & +o. 006 & $5 \mathrm{I}-52$ & 3.452 & -0.015 & $66-67$ & 3.435 & +0.037 & & & \\
\hline
\end{tabular}

* At this point the focal adjustment of Micrometer A was changed.

There is nothing in these measures to show a progressive error in this screw. With one exception, these residuals are of the same order as those of the Clark Micrometer II. The one larger residual, +o'.I4O, is probably due to a large accidental error in setting Micrometer $\mathrm{A}$ for that revolution.

$28 \mathrm{I} 67^{\circ}$-VOL 6 -II-III 


\begin{tabular}{|c|c|c|c|c|c|c|c|c|}
\hline \multirow{2}{*}{$\begin{array}{l}\text { W. and S. } \\
\text { Microm. }\end{array}$} & \multirow{2}{*}{$\begin{array}{c}\text { First } \\
\text { Quarter. }\end{array}$} & \multirow{2}{*}{$\begin{array}{l}\text { Second } \\
\text { Quarter. }\end{array}$} & \multirow{2}{*}{$\begin{array}{c}\text { Third } \\
\text { Quarter. }\end{array}$} & \multirow{2}{*}{$\begin{array}{l}\text { Fourth } \\
\text { Quarter. }\end{array}$} & \multicolumn{4}{|c|}{ Residuals from Mean. } \\
\hline & & & & & $\begin{array}{c}\text { First } \\
\text { Quarter. }\end{array}$ & $\begin{array}{l}\text { Second } \\
\text { Quarter. }\end{array}$ & $\begin{array}{c}\text { Third } \\
\text { Quarter. }\end{array}$ & $\begin{array}{c}\text { Fourth } \\
\text { Quarter. }\end{array}$ \\
\hline rev. & rev. & rev. & rev. & rev. & " & $\prime \prime$ & $\prime \prime$ & 11 \\
\hline $22-23$ & o. 794 & 0.806 & o. 799 & o. 783 & +o. 005 & -0.053 & -0.019 & +0.058 \\
\hline $23^{-24}$ & o. 797 & o. 794 & o. 807 & o. 800 & -0.010 & +0.005 & -0.058 & -0.024 \\
\hline $24-25$ & o. $79^{6}$ & o. 804 & o. 807 & o. 788 & -0.005 & -0.044 & -0.058 & +o. 034 \\
\hline $25^{-26}$ & o. 794 & 0.807 & o. 793 & o. 794 & to 005 & -0.058 & to. o10 & +o. 005 \\
\hline $26-27$ & o. 790 & o. $80_{5}$ & o. 799 & o. 800 & +0.024 & -0.048 & -0.019 & -0.024 \\
\hline $27-28$ & o. 806 & o. 790 & o. 797 & o. 799 & -0.053 & +o. 024 & -0.010 & -0.019 \\
\hline $28-29$ & o. 800 & o. 805 & o. 790 & o. 794 & -0.024 & -0.048 & +o. 024 & +0.005 \\
\hline $29-30$ & o. 790 & o. 805 & o. 790 & o. 794 & +0.024 & -0.048 & +0.024 & to. 005 \\
\hline $30-3 \mathrm{I}$ & o. 792 & o. 787 & o. 786 & o. 797 & to. o1 5 & to. 039 & to. 044 & -0.010 \\
\hline $3 I-32$ & o. 789 & o. 800 & o. 784 & o. 788 & +0.029 & -0.024 & +0.053 & +0.034 \\
\hline $32-33$ & o. 794 & o. 785 & o. 787 & o. 79.5 & to. 005 & +o. 048 & +o. 039 & o. 000 \\
\hline $33-34$ & o. 787 & o. 785 & o. 799 & o. 780 & +o. 039 & to. 048 & -0.019 & +o. 07.3 \\
\hline $34-35^{*}$ & o. $85^{8}$ & o. 862 & o. 862 & 0.862 & +o. 012 & o. 000 & 0.000 & 0.000 \\
\hline $35-3^{6}$ & o. $85^{8}$ & o. 8.57 & $0.87 \mathrm{I}$ & o. 864 & +o.012 & +o.015 & -0.028 & -0.006 \\
\hline $36-37$ & o. 860 & o. $85^{6}$ & o. 874 & o. 854 & +o. 006 & +o.018 & $-0.03 \pi$ & +0.025 \\
\hline $37-38$ & 0.865 & o. $85^{2}$ & o. 875 & 0.860 & -0.009 & +0.031 & -0.040 & +o. 006 \\
\hline $3^{8-39}$ & 0.860 & o. 854 & o. 873 & o. 85.3 & +o.co6 & to. 025 & -0.034 & +0.028 \\
\hline $39-40$ & o. $85^{6}$ & o. 859 & 0.864 & o. 864 & to. 018 & +o. oo9 & -0.006 & -0.006 \\
\hline $40-4 x$ & 0.858 & 0.864 & o. 869 & o. 878 & +o. 012 & -0.006 & $-0.02 \mathrm{I}$ & -0.049 \\
\hline $4 I-42$ & 0.870 & 0.865 & o. 853 & o. 873 & -0.025 & -0.009 & +0.028 & $\begin{array}{lll}-0 & 0.34\end{array}$ \\
\hline $42-43$ & 0.863 & 0.862 & 0.858 & 0.862 & -0.003 & o. 000 & +o. 012 & 0.000 \\
\hline $43-44$ & 0.866 & 0.862 & 0.864 & $0.86 \mathrm{I}$ & -0.012 & 0.000 & -0.006 & +0.003 \\
\hline $44-45$ & o. 866 & o. 860 & o. 862 & o. 870 & -0.012 & +o. 006 & o. 000 & -0.025 \\
\hline $45-46$ & o. 870 & o. 848 & 0.880 & o. 860 & -0.025 & to. 043 & -0.055 & to. 006 \\
\hline $46-47$ & 0.856 & o. 863 & 0.864 & o. 865 & +o.01 8 & -0.003 & -0.006 & -0.009 \\
\hline $47-48$ & $0.86 \mathrm{r}$ & o. 859 & o. 869 & o. 856 & +0.003 & +0.009 & $-0.02 \mathrm{I}$ & +0.018 \\
\hline $48-49$ & 0.862 & $0.86 \mathrm{r}$ & o. 863 & o. 874 & o. 000 & +o. 003 & -0.003 & -0.037 \\
\hline $49-50$ & o. 857 & o. 867 & o. 864 & 0.867 & to. or 5 & -0.015 & -0.006 & -0.015 \\
\hline $50-5 \mathrm{I}$ & o. 863 & $0.85 \mathrm{I}$ & o. 866 & o. 857 & -0.003 & to. 028 & -0.012 & +o.015 \\
\hline $5^{1-52}$ & o. $862^{\circ}$ & o. 866 & o. 864 & o. 860 & o. 000 & -0.012 & -0.006 & +o. 006 \\
\hline $5^{2--53}$ & 0.864 & 0.853 & o. 865 & o. 865 & -0.006 & +0.028 & -0.009 & -0.009 \\
\hline $53-54$ & o. 854 & o. 857 & o. 874 & o. 857 & +o. 025 & +o.015 & -0.037 & to. 015 \\
\hline $54-55$ & $0.86 \mathrm{I}$ & 0.852 & o. 866 & o. $87 \mathrm{I}$ & +0.003 & to.03I & -0.012 & -0.028 \\
\hline $55^{-56}$ & o. 860 & $0.86 \mathrm{I}$ & o. 867 & o. 864 & +o. 006 & +o. 003 & -0.015 & -0.006 \\
\hline $5^{6-57}$ & o. 856 & o. 864 & o. 868 & $0.86 \mathrm{I}$ & to. 018 & -0.006 & -о. о18 & to. 006 \\
\hline $57-5^{8}$ & o. 863 & o. 864 & 0.870 & o. 868 & -0.003 & -0.006 & -0.025 & -0.018 \\
\hline $5^{8-59}$ & o. 856 & o. 864 & o. 860 & 0.867 & to. 018 & -0.006 & +o. 006 & -0.015 \\
\hline $59-60$ & o. 859 & o. 855 & o. $87^{\circ}$ & o. $85^{8}$ & +o. 009 & +0.021 & -0.025 & +o.012 \\
\hline $60-6 I$ & o. 856 & o. 860 & o. 869 & o. 852 & +0.018 & +0.006 & -0.021 & $+0.03 \mathrm{I}$ \\
\hline $61-62$ & o. 860 & o. 852 & $0.87 \mathrm{I}$ & $0.86 \mathrm{I}$ & +o. 006 & +o. 03 J & -0.028 & to. 003 \\
\hline $62-63$ & o. 862 & o. 856 & o. 868 & o. 868 & 0.000 & +o. о1 8 & -0.018 & -0.018 \\
\hline $63-64$ & o. 860 & o. 854 & o. 866 & o. 860 & +o. 006 & +o. 025 & -0.012 & +o. 006 \\
\hline $64-65$ & o. 862 & o. 852 & o. 864 & o. 865 & 0.000 & $+0.03 \mathrm{I}$ & -0.006 & -0.009 \\
\hline
\end{tabular}

* At this point the focal adjustment of Micrometer A was changed. 
TABLE V.-Showing Inequalities in the Quarter Revolutions as Measured by Different Parts of Micrometer A - Continued.

\begin{tabular}{|c|c|c|c|c|c|c|c|c|}
\hline \multirow{2}{*}{$\begin{array}{l}\text { W. and S. } \\
\text { Microm. }\end{array}$} & \multirow{2}{*}{$\begin{array}{c}\text { First } \\
\text { Quarter. }\end{array}$} & \multirow{2}{*}{$\begin{array}{l}\text { Second } \\
\text { Quarter. }\end{array}$} & \multirow{2}{*}{$\begin{array}{c}\text { Third } \\
\text { Quarter. }\end{array}$} & \multirow{2}{*}{$\begin{array}{l}\text { Fourth } \\
\text { Quarter. }\end{array}$} & \multicolumn{4}{|c|}{ Residuals from Mean. } \\
\hline & & & & & $\begin{array}{c}\text { First } \\
\text { Quarter. }\end{array}$ & $\begin{array}{l}\text { Second } \\
\text { Quarter. }\end{array}$ & $\begin{array}{l}\text { Third } \\
\text { Quarter. }\end{array}$ & $\begin{array}{c}\text { Fourth } \\
\text { Quarter. }\end{array}$ \\
\hline rev. & rev. & rev. & rev. & rev. & $" \prime$ & $" \prime$ & $" \prime$ & $" \prime$ \\
\hline $65-66$ & o. 856 & o. 855 & o. 873 & o. 860 & +o. or 8 & $+0.02 \mathrm{I}$ & -0.034 & +o. 006 \\
\hline $66-67$ & o. 857 & o. 853 & o. 869 & o. 856 & +o. 015 & +o. 028 & $-0.02 \mathrm{I}$ & +o. 018 \\
\hline $67-68$ & 0.862 & o. 856 & o. 862 & o. 867 & o. 000 & +o. o1 8 & o. 000 & -0.015 \\
\hline $68-69$ & o. 868 & o. 847 & o. $87 \mathrm{I}$ & o. 865 & -0.018 & +o. 046 & -0.028 & -0.009 \\
\hline $69-70$ & o. 857 & o. 850 & o. 877 & 0.857 & +0.015 & +o. 037 & -0.046 & +o. o1 5 \\
\hline $70-71$ & o. 866 & o. 848 & o. 875 & o. $85^{8}$ & -0.012 & +o. 04.3 & -0.040 & +o. 012 \\
\hline $71-72$ & o. 863 & o. 854 & o. 862 & o. 872 & -0.003 & +o. 025 & o. 000 & $-0.03 I$ \\
\hline $72-73$ & $0.86 \mathrm{I}$ & 0.856 & o. 868 & o. 854 & +o. 003 & +о. ог 8 & -0.018 & +0.025 \\
\hline $73-74$ & o. 863 & o. 855 & o. 860 & o. 870 & -0.003 & +o. 021 & +o. 006 & -0.025 \\
\hline $74-7.5$ & 0.862 & o. 854 & o. 862 & o. 866 & o. 000 & to. 025 & o. 000 & -0.012 \\
\hline $75-76$ & o. 855 & o. 848 & o. $87 \mathrm{I}$ & o. 860 & $+0.02 \mathrm{I}$ & to. 043 & -0.028 & +o. 006 \\
\hline $76-77$ & o. 864 & o. $85^{2}$ & o. $86 \mathrm{I}$ & o. 848 & -0.006 & +o. 031 & +o. 003 & to. 043 \\
\hline $77-78$ & o. 860 & o. $85^{8}$ & 0.862 & o. 863 & +0.006 & +o. OI 2 & o. 000 & -0.006 \\
\hline $78-79$ & o. 862 & $0.85 \mathrm{I}$ & o. 865 & o. 859 & o. 000 & +o. 028 & -0.009 & +o. 009 \\
\hline $79-80$ & o. 879 & o. 856 & o. 866 & o. $85^{2}$ & -0.052 & +o. oI 8 & -0.012 & $+0.03 \mathrm{I}$ \\
\hline
\end{tabular}

The mean of the residuals for the first quarter is $\ldots \ldots \ldots \ldots \ldots \ldots+0^{\prime \prime} .0026$ The mean of the residuals for the second quarter is ............ The mean of the residuals for the third quarter is $\ldots \ldots \ldots \ldots \ldots \ldots-\mathrm{o}^{\prime \prime}$.or 17 The mean of the residuals for the fourth quarter is $\ldots \ldots \ldots \ldots \ldots \ldots+\mathrm{o}^{\prime \prime} .0017$

The formula for periodic errors is :

$$
\varphi(u)=-\mathrm{o}^{\prime \prime} .0057, \cos u+\mathrm{o}^{\prime \prime} .0015 \sin u+\mathrm{o}^{\prime \prime} .0026 \cos 2 u \text {. }
$$

TABLE VI.-Showing Irequalities in the Quarter Revolutions from 47 Revolutions to 53 Revolutions as Measured by the Same Part of Micrometer A.

\begin{tabular}{|c|c|c|c|c|c|c|c|c|}
\hline \multirow{2}{*}{$\begin{array}{l}\text { W. and S. } \\
\text { Microm. }\end{array}$} & \multirow{2}{*}{$\begin{array}{c}\text { First } \\
\text { Quarter. }\end{array}$} & \multirow{2}{*}{$\begin{array}{c}\text { Second } \\
\text { Quarter. }\end{array}$} & \multirow{2}{*}{$\begin{array}{c}\text { Third } \\
\text { Quarter. }\end{array}$} & \multirow{2}{*}{$\begin{array}{l}\text { Fourth } \\
\text { Quarter. }\end{array}$} & \multicolumn{4}{|c|}{ Residuals from Mean. } \\
\hline & & & & & $\begin{array}{c}\text { First } \\
\text { Quarter. }\end{array}$ & $\begin{array}{l}\text { Second } \\
\text { Quarter. }\end{array}$ & $\begin{array}{l}\text { Third } \\
\text { Quarter. }\end{array}$ & $\begin{array}{c}\text { Fourth } \\
\text { Quarter. }\end{array}$ \\
\hline rev. & rev. & rev. & rev. & rev. & " & $\prime \prime$ & " & " \\
\hline $47-48$ & o. 865 & o. $85^{8}$ & o. 869 & o. 860 & $-0.02 \mathrm{I}$ & 0.000 & -0.034 & -0.006 \\
\hline $48-49$ & o. $86 x$ & o. 863 & o. 864 & o. 853 & -0.009 & -0.015 & -0.018 & +o.015 \\
\hline $49-50$ & o. 850 & o. $85^{\circ}$ & o. 837 & o. 854 & +o. 025 & to. 025 & +o. 064 & to. or 2 \\
\hline $5 \mathrm{I}-5^{2}$ & o. 862 & o. 855 & o. 856 & o. 860 & -0. 01 2 & +0.009 & +o. 006 & -0.006 \\
\hline $52-53$ & o. 856 & o. $86 \mathrm{I}$ & o. 864 & o. 866 & +o. 006 & -0.009 & -0.018 & -0.025 \\
\hline
\end{tabular}

The mean of the residuals for the first quarter is . . . . . . . . . . . The mean of the residuals for the second quarter is . . . . . . . . . . The mean of the residuals for the third quarter is . . . . . . . . . . . . . . The mean of the residuals for the fourth quarter is $\ldots \ldots \ldots \ldots \ldots \ldots-\mathrm{o}^{\prime \prime} .0020$ 
These residuals give as the formula for periodic errors:

$$
\phi(u)=-\mathrm{o}^{\prime \prime} .0004 \cos u-\mathrm{o}^{\prime \prime} .0016 \sin u+\mathrm{o}^{\prime \prime} .0002 \cos 2 u \text { 。 }
$$

If any periodic error in this screw exists it must be extremely small. The screw seems to be a very excellent one in all respects. This micrometer has been used on two occasions only, and the adopted value of one revolution is $\mathrm{IO}^{\prime \prime} .565$.

The double-image micrometer. - The instrument is provided with a double-image micrometer made by ALVAN CLARK and Sons. It has the advantage of a larger field of view than ordinary instruments of this construction.

The position circle. - The position circle, by The WARNER and SWASEY Company, is $9 \frac{1}{4}$ inches in diameter and is graduated to half degrees. It is read by two verniers, designated as I and II, the least reading being $0^{\circ} .02$. Two determinations of the eccentricity of the position circle have been made, one by C. W. FREDERICK in October, I903, and one by J. C. Hammond in September, I905. (See TABLES VII, VIII.)

TABLE VII.-Readings of the Two Verniers, by C. W. Frederick.

\begin{tabular}{|c|c|c|c|c|c|c|c|c|c|c|c|}
\hline $\begin{array}{c}\text { Vernier } \\
\text { I. }\end{array}$ & $\begin{array}{c}\text { Vernier } \\
\text { II. }\end{array}$ & $\begin{aligned} & I-I I \\
+ & 180^{\circ}\end{aligned}$ & $\begin{array}{c}\text { Vernier } \\
\text { I. }\end{array}$ & $\begin{array}{c}\text { Vernier } \\
\text { II. }\end{array}$ & $\begin{array}{l}I-I I \\
+ \\
+180^{\circ}\end{array}$ & $\begin{array}{c}\text { Vernier } \\
\text { I. }\end{array}$ & $\begin{array}{c}\text { Vernier } \\
\text { II. }\end{array}$ & $\begin{array}{r}I-I I \\
+I 80^{\circ}\end{array}$ & $\begin{array}{c}\text { Vernier } \\
\text { I. }\end{array}$ & $\begin{array}{l}\text { Verniet } \\
\text { II. }\end{array}$ & $\begin{aligned} & \mathrm{I}-\mathrm{II} \\
+ & \mathrm{I} 80^{\circ}\end{aligned}$ \\
\hline$\circ$ & 。 & 。 & $\circ$ & ○ & 。 & $\circ$ & $\circ$ & $\circ$ & 。 & $\circ$ & $\circ$ \\
\hline 0.025 & 180.005 & +0.020 & 60.050 & 240.045 & +o. 005 & 250.005 & 70.010 & -0.005 & 305.020 & 125.010 & +o.010 \\
\hline 4. 995 & I 84.975 & +0.020 & 65.025 & 245.025 & o. 000 & 255.005 & 75. OIO & -0.005 & 3 10. 035 & 130.020 & +0.015 \\
\hline 10. 040 & 190.020 & +0.020 & 70.030 & 250.030 & o. 000 & 260.015 & 80.020 & -0.005 & $3 \times 5.020$ & I35.005 & +o. 015 \\
\hline 15.035 & 195.020 & +o.015 & 75.005 & 255.005 & o. 000 & 265.015 & 85.020 & -0.005 & 320.025 & 140.015 & to. o10 \\
\hline 20.040 & 200.020 & +0.020 & 80.020 & 260.020 & o. 000 & 270.005 & 90.005 & o. 000 & 325.025 & 145.015 & to. oIO \\
\hline 25.020 & 205.005 & +0.015 & 85.005 & $26_{5} .005$ & 0.000 & 275.025 & 95.025 & o. 000 & 330.035 & I 50.020 & +o.015 \\
\hline 30.020 & 210.000 & +0.020 & 90.025 & 270.025 & 0.000 & $280.00_{5}$ & I00. 000 & +o. 005 & 335.000 & I 54.985 & +o.015 \\
\hline 35.000 & 214.985 & +o.015 & 95.010 & 275.015 & -0.005 & 285.010 & 105.005 & +o. 005 & 340.020 & 160.005 & +o.or 5 \\
\hline 40.045 & 220.035 & to. 010 & 100.015 & 280.015 & o. 000 & 290.025 & I 10. OI 5 & +o. ого & 345.045 & 165.025 & +0.020 \\
\hline 45.015 & 225.005 & to. 010 & 105.015 & 285.020 & -0.005 & 295.020 & Iis.oro & to.010 & 350.015 & 169.995 & +0.020 \\
\hline 50.040 & 230.035 & +0.005 & 109.990 & 289.995 & $-0.00_{5}$ & 300.035 & 120.025 & to. & 355.015 & 175.000 & +o. or 5 \\
\hline 55.015 & 235.005 & +o. 010 & & & & & & & & & \\
\hline
\end{tabular}


TABLE VIII.-Readings of the Tro Verniers, by J. C. Hammond.

\begin{tabular}{|c|c|c|c|c|c|c|c|c|c|c|c|}
\hline $\begin{array}{c}\text { Vernier } \\
\text { I. }\end{array}$ & $\begin{array}{l}\text { Vernier } \\
\text { II. }\end{array}$ & $\begin{aligned} & \mathrm{I}-\mathrm{II} \\
+ & \mathrm{I} 80^{\circ}\end{aligned}$ & $\begin{array}{c}\text { Vernier } \\
\text { I. }\end{array}$ & $\begin{array}{c}\text { Vernier } \\
\text { II. }\end{array}$ & $\begin{aligned} & I-I I \\
+ & I 80^{\circ}\end{aligned}$ & $\begin{array}{c}\text { Vernier } \\
\text { I. }\end{array}$ & $\begin{array}{c}\text { Vernier } \\
\text { II. }\end{array}$ & $\begin{aligned} & I-I I \\
+ & 180^{\circ}\end{aligned}$ & $\begin{array}{c}\text { Vernier } \\
\text { I. }\end{array}$ & $\begin{array}{c}\text { Vernier } \\
\text { II. }\end{array}$ & $\begin{array}{r}\text { I-II } \\
+180^{\circ}\end{array}$ \\
\hline$\circ$ & ० & ○ & $\circ$ & $\circ$ & 。 & $\circ$ & 。 & $\circ$ & $\circ$ & $\circ$ & $\circ$ \\
\hline 0.00 & I 79.980 & to. 020 & 90.00 & 270.005 & -0.005 & I 80.00 & 0.020 & -0.020 & 270.00 & 90.000 & 0.000 \\
\hline 5.00 & I 84.980 & +0.020 & 95.00 & 275.005 & -0.005 & 185.00 & 5.020 & -0.020 & 275.00 & 9.5 .000 & 0.000 \\
\hline 10. 00 & 189.980 & to. 020 & 100. 00 & 280.010 & -0.010 & 190.00 & 10.020 & -0.020 & 280.00 & 100.000 & o. 000 \\
\hline 15.00 & $194.9^{8} 5$ & to.015 & 105.00 & 285 . oro & $-0.010^{1}$ & 195.00 & 15.020 & -0.020 & 285.00 & 104.990 & to. OIO \\
\hline 20.00 & $199.9^{8} 5$ & †o.015 & I 10. OO & 290.015 & -0.015 & 200.00 & 20.020 & -0.020 & 290.00 & 109.990 & to.010 \\
\hline 25.00 & 204.990 & to.010 & I I 5.00 & 295.015 & -0.015 & 205.00 & 25.015 & -0.015 & 295.00 & 114.985 & +o.015 \\
\hline 30.00 & 209.980 & +0.020 & I 20.00 & 300.015 & -0.015 & 210.00 & 30.015 & -O. OI 5 & 300.00 & $\operatorname{II} 9.9^{8} 5$ & +o.01 5 \\
\hline 35.00 & 214.990 & to. oio & 125.00 & 305.020 & -0.020 & 215.00 & 35.015 & -o. OI 5 & 305.00 & $124.9^{8} 5$ & +o.01 5 \\
\hline 40.00 & 219.990 & +o.010 & I 30.00 & 3 10. 020 & -0.020 & 220.00 & 40.015 & -0.015 & 310.00 & I 29.980 & +0.020 \\
\hline 45.00 & 224.990 & +o.oro & 135.00 & 315.025 & -0.025 & 225.00 & 45.015 & -0.015 & 315.00 & I $34.9^{80}$ & +0.020 \\
\hline 50.00 & 229.995 & +o.005 & 140.00 & $320.025 \mid$ & -0.025 & 230.00 & 50. 010 & -0. о10 & 320.00 & I 39.980 & +0.020 \\
\hline 55.00 & 234.995 & +0.005 & I 45.00 & 325.025 & -0.025 & 235.00 & 55.015 & -0.015 & 325.00 & I 44.975 & +0.025 \\
\hline 6o: 00 & 239.995 & +0.005 & I 50.00 & 330.025 & -0.025 & 240.00 & 60.015 & -0.015 & 330. oo & r 49.980 & +0.020 \\
\hline 65.00 & 244.995 & +0.005 & 155.00 & 335.025 & -0.025 & 245.00 & 65.010 & -o. oro & 335.00 & I 54.980 & +o. 020 \\
\hline 70.00 & 249.995 & +0.005 & 160.00 & 340.030 & -0.030 & 250.00 & 70.010 & -0.010 & 340.00 & I 59.980 & to. 020 \\
\hline 75.00 & 255.000 & 0.000 & I65.00 & 345.030 & -0.030 & 255.00 & 75.015 & -0.015 & 345.00 & I64.975 & +0.025 \\
\hline 80.00 & 260.000 & 0.000 & I 70.00 & 350.025 & -0.025 & 260.00 & 80.005 & -0.005 & 3.50 .00 & I69. 980 & to. 020 \\
\hline 85.00 & 265.005 & -0.005 & 175.00 & 355.020 & -0.020 & 265.00 & 85.005 & -0.005 & 355.00 & $\mathrm{r} 74.98 \mathrm{O}$ & +0.020 \\
\hline
\end{tabular}

From these measures it will be seen that the eccentricity is small and no correction for it has been applied to the observations in position angle previous to the year I903, although one vernier only was read. However, commencing with the year 1903 it was deemed advisable to apply such a correction to the observations of the satellites. It has been the custom since that time to observe always with the micrometer head up, and to read that vernier which gives the proper position angle. With the instrument east of the pier, position angles from $270^{\circ}$ through $0^{\circ}$ to $90^{\circ}$ are read from Vernier I, and angles from $90^{\circ}$ through $180^{\circ}$ to $270^{\circ}$ from Vernier II, and vice versa, for the instrument west of the pier.

If $P$ is the reading of the vernier which gives the proper position angle, in distinction from the vernier $180^{\circ}$ from it, then the reading $P$ will require a correction for eccentricity.

Instrument east of pier $\left\{\begin{array}{l}\Delta P=+0^{\circ} . \text { oro } \sin \left(P-90^{\circ}\right) \ldots \ldots \ldots \ldots \ldots \ldots \text { FrEDERICK } \\ \Delta P=+0^{\circ} . \text { or } \sin \left(P-80^{\circ}\right) \ldots \ldots \ldots \ldots \text { HAMmOND }\end{array}\right.$

When the instrument is west of the pier the sign of the correction is changed. 
TABLE IX.-Correction for Eccentricity of Position Circle with the Instrument East of the Pier and the Micrometer Head Up.

\begin{tabular}{|c|c|c|c|c|c|c|c|c|}
\hline \multirow{2}{*}{$P$} & \multicolumn{2}{|c|}{$\Delta P$} & \multirow{2}{*}{$P$} & \multicolumn{2}{|c|}{$\Delta P$} & \multirow{2}{*}{$P$} & \multicolumn{2}{|c|}{$\Delta P$} \\
\hline & Fk. & $\mathrm{Hd}$. & & Fk. & Hd. & & Fk. & Hd. \\
\hline$\circ$ & $\circ$ & $\circ$ & $\circ$ & $\circ$ & $\circ$ & 。 & $\circ$ & 。 \\
\hline o & -0.010 & $-0.01 \mathrm{I}$ & 60 & -0.005 & -0.004 & 120 & +0.005 & +o. 007 \\
\hline 5 & -0.010 & $-0.01 \mathrm{I}$ & 65 & -0.004 & -0.003 & 125 & +o. 006 & +o. 008 \\
\hline IO & -о. оіо & -0.010 & 70 & -0.003 & -0.002 & 130 & +o. 006 & +o. 008 \\
\hline 15 & -0. 010 & -0.010 & 75 & -0.002 & -0.001 & I 35 & +0.007 & +o. 009 \\
\hline 20 & -0.009 & -o. oro & 80 & -0.002 & o. 000 & 140 & +o. 008 & +o. 010 \\
\hline 25 & -0.009 & -0.009 & 85 & -0.001 & +o. OOI & 145 & +0.008 & +o. o10 \\
\hline 30 & -0.009 & -0.008 & 90 & o. 000 & +o. 002 & 150 & +o. 009 & to. 010 \\
\hline 35 & -0.008 & -0.008 & 95 & +o. OOI & +0.003 & I 55 & +o. 009 & +o. ox I \\
\hline 40 & -0.008 & -0.007 & IOo & +0.002 & +o. 004 & 160 & +0.009 & +o. 011 \\
\hline 45 & -0.007 & -0.006 & 105 & +o. 003 & +o. 005 & 165 & +o. 010 & to. 011 \\
\hline 50 & -0.006 & -0.005 & I IO & +0.003 & +o. 005 & 170 & to. 010 & to. 011 \\
\hline 55 & -0.006 & -0.005 & II 5 & +o. 004 & +o. OOC & 175 & to.010 & to. 011 \\
\hline \multirow{2}{*}{$P$} & \multicolumn{2}{|c|}{$\Delta P$} & \multirow{2}{*}{$P$} & \multicolumn{2}{|c|}{$\Delta P$} & \multirow{2}{*}{$P$} & \multicolumn{2}{|c|}{ 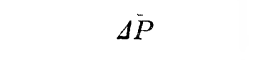 } \\
\hline & Fk. & $\mathrm{Hd}$. & & Fk. & Hd. & & Fk. & Hd. \\
\hline$\circ$ & $\circ$ & 。 & 。 & 。 & $\circ$ & 。 & $\circ$ & 。 \\
\hline I 80 & to. oro & to.or I & 240 & +0.005 & +o. 004 & 300 & -0.005 & -0.007 \\
\hline 185 & +o.010 & to. or I & 245 & +o. 004 & +o. 003 & 305 & -0.006 & -0.008 \\
\hline I9O & to. oro & to. oro & 250 & +0.003 & +0.002 & 310 & -0.006 & -0.008 \\
\hline 195 & to. o10 & to. 010 & 255 & +o. 003 & to. oor & 315 & -0.007 & -0.009 \\
\hline 200 & to. oro & to. oro & 260 & +o. 002 & o. 000 & 320 & -0.008 & -0.010 \\
\hline 205 & to. 009 & +0.009 & 265 & +o. OOI & -0.001 & 325 & -0.008 & -o. 010 \\
\hline 210 & +o. 009 & +o. 008 & 270 & o. 000 & -0.002 & 330 & -0.009 & -0.010 \\
\hline 215 & +o. 008 & +o. 008 & 275 & -0.001 & -0.003 & 335 & -0.009 & -O. OII \\
\hline 220 & +o. 008 & +0.007 & 280 & -0.002 & -0.004 & 340 & -0.009 & $-0.01 \mathrm{I}$ \\
\hline 225 & +0.007 & +0.006 & 285 & -0.003 & -0.005 & 345 & -0. ого & -O. OI I \\
\hline 230 & +o. 006 & +0.005 & 290 & -0.003 & -0.005 & $35^{\circ}$ & -o. о10 & -O.OII \\
\hline 235 & +0.006 & +0.005 & 295 & -0.004 & -0.006 & 355 & -0.010 & -O. OII \\
\hline
\end{tabular}

The eyepieces. - There are two sets of negative eyepieces which fit into the draw tube of the telescope when the micrometer is removed. One set consists of four eyepieces of the AIRY pattern, made by ALVAN CLARK and Sons at the time the original mounting was constructed. The other set is composed of nine eyepieces of the AIRY-Huygentan type and one Herschel solar prism, all made by M. E. KAHLER. Their magnifying powers are approximately as follows: 
Set I. Negative Eyepieces.

\begin{tabular}{|c|c|c|c|}
\hline $\begin{array}{l}\text { Desig- } \\
\text { nation. }\end{array}$ & $\begin{array}{c}\text { Magnifying } \\
\text { Power. }\end{array}$ & $\begin{array}{l}\text { Field of } \\
\text { View. }\end{array}$ & Makers. \\
\hline & Diameters. & $'$ & \\
\hline $\mathrm{A}_{\mathrm{I}}$ & 155 & 25.2 & Clark and Sons. \\
\hline $\mathrm{A}_{\mathrm{II}}$ & 439 & 10. 5 & “ \\
\hline$A_{I I I}$ & 863 & $3 \cdot 5$ & “ \\
\hline $\mathrm{A}_{\text {IIIII }}$ & I, 360 & 2.5 & “ \\
\hline
\end{tabular}

Taken from the Washington Observations for 1874 , Vol. XXI, Appendix I.

The positive eyepieces are as follows:

Positive Eyepieces.

\begin{tabular}{|c|c|c|c|c|}
\hline $\begin{array}{l}\text { Designa- } \\
\text { tion. }\end{array}$ & $\begin{array}{l}\text { Magnifying } \\
\text { Power. }\end{array}$ & $\begin{array}{l}\text { Field of } \\
\text { View }\end{array}$ & Makers. & Remarks. \\
\hline I & $\begin{array}{c}\text { Diameters. } \\
173\end{array}$ & $\stackrel{1}{\mathrm{I} 3.2}$ & Clark and Sons. & \\
\hline I $\mathrm{A}$ & 178 & I 2.0 & & \\
\hline 2 & 252 & $9 \cdot 3$ & & \\
\hline $2 \mathrm{~A}$ & 284 & 8. $\mathrm{I}$ & Kahler. & \\
\hline 3 & 392 & $9 \cdot 9$ & Clark and Sons. & \\
\hline $3 \mathrm{~A}$ & 375 & 6.6 & Kahler. & Achromatic. \\
\hline $3 \mathrm{~B}$ & 388 & 6.5 & & \\
\hline $3 \mathrm{C}$ & 360 & 7.8 & Kahler. & \\
\hline $5 \mathrm{~A}$ & $5^{25}$ & 4.2 & Kahler. & Achromatic. \\
\hline $6 \mathrm{~A}$ & 888 & 2.3 & Steinheil. & Achromatic. \\
\hline $7 \mathrm{C}$ & 761 & $3 \cdot 2$ & Kahler. & Crown glass. \\
\hline $8 \mathrm{C}$ & $77 \mathrm{r}$ & 3.0 & & \\
\hline $8 \mathrm{~F}$ & 875 & 3.2 & Kahler. & Flint glass. \\
\hline 9 & I, 103 & 2.6 & Kahler. & \\
\hline IO & I, 282 & 2. I & Kahler. & \\
\hline I I & $\mathrm{I}, 802$ & I. 6 & Kahler. & \\
\hline I & 390 & $4 \cdot 9$ & Kahler. & Single lens. \\
\hline II & 585 & 3.2 & Kahler. & Single lens. \\
\hline III & 780 & 2.6 & Kahler. & Single lens. \\
\hline IV & 1,560 & I. 8 & Kahler. & Single lens. \\
\hline
\end{tabular}

The magnifying powers of $\mathrm{I}, 2 \mathrm{~A}, 3,6 \mathrm{~A}, 7 \mathrm{C}, 8 \mathrm{~F}, 9$, Io, $\mathrm{xI}, \mathrm{I}$, II, III, and IV are the same as given in the Washington Observations for I874, Volume XXI, Appendix I. The others have been determined recently with the RAMSDEN dynameter made for use with the telescope by EDWARD KAHLER.
Set 2. Negative Eyepieces.

\begin{tabular}{|c|c|c|c|}
\hline $\begin{array}{l}\text { Desig- } \\
\text { nation. }\end{array}$ & $\begin{array}{l}\text { Magnifying } \\
\text { Power. }\end{array}$ & $\begin{array}{l}\text { Field of } \\
\text { View. }\end{array}$ & Makers. \\
\hline I & $\begin{array}{c}\text { Diameters. } \\
9^{8}\end{array}$ & $\stackrel{\prime}{33.1}$ & Kahler. \\
\hline II & I 38 & 25.6 & " \\
\hline III & 195 & 17.6 & “" \\
\hline IV & 276 & 12.8 & “" \\
\hline $\mathrm{V}$ & 390 & 8.8 & “ \\
\hline $\mathrm{VI}$ & $55^{I}$ & $5 \cdot 3$ & “" \\
\hline VII & 780 & 4.4 & “" \\
\hline VIII & I, 103 & 2.6 & “ \\
\hline IX & 1,560 & I. 3 & “ \\
\hline
\end{tabular}

From a manuscript by Prof. WM. Harkness. 
The chronographs.-Until October, I897, one of the transit-of-Venus chronographs was used in connection with this instrument. After this date, the CLARK chronograph, properly belonging to the instrument and described in the Washington Observations for I874, Volume XXI, Appendix I, page 4I, was used. It had been necessary to lessen the fall of the driving weights of the CLARK chronograph from ro6 to 36 inches.

The chronograph has always been connected with a NEGUS break-circuit sidereal chronometer, the correction to which has been determined by direct comparison with one of the standard clocks.

The instrumental constants. - Two determinations of $\xi$ and $n$, the coordinates of the polar axis, were made by Professor Brown.

The coordinate $\xi$ was determined on one night and the coordinate $n$ on four nights by Professor SEE. He also derived from his observations a value of $e$, the flexure of the telescope tube, and of $i_{1}$, the inclination of the axes, using in his determination of $i_{1}$, the value of the collimation which he obtained by the aid of a small collimator. His results are printed in Publications of the United States Naval Observatory, Second Series, Volume III, Part I. His published value of $i_{1}$ is erroneous, due to the omission in his reductions of a term depending on the flexure of the

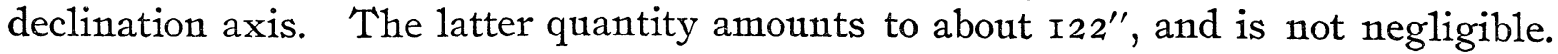

In 1902 and 1903 a thorough investigation of the constants of this instrument was made by Assistant C. W. FREDERICK, and his results, with the method of obtaining the same, are printed in Publications of the United States Naval Observatory, Second Series, Volume IV, Appendix III. Tables constructed by Mr. FredERICK for correcting observations for the effect of the instrumental constants are also given in the above-mentioned publication.

Subsequent determinations of these constants have been made by Mr. HAMmond, and the results of all the determinations are collected in the following table, using the notation adopted by Mr. Frederick.

$\eta=$ the distance of the instrumental pole westward from the true pole, measured along the sixhour circle.

$\xi=$ the distance of the instrumental pole above the true pole, measured along the meridian.

$i_{1}=$ the inclination of the axes. The angle between the polar axis produced northward and the declination axis produced through the telescope tube is $i_{1}+90^{\circ}$. This is the observed angie as affected by the flexure of the declination axis.

$c=$ the collimation. The angle between the optical axis of the telescope produced through the objective and the declination axis produced through the tube is $c+90^{\circ}$.

$\varepsilon=$ the maximum flexure of the declination axis, positive when the end joining the tube bends downward.

$e=$ the maximum flexure of the telescope tube, positive when the objective end of the tube bends the more. 
Summary of Determinations of the Instrumental Constants of the 26-inch Equatorial.

\begin{tabular}{|c|c|c|c|c|c|c|c|c|c|c|}
\hline \multirow[b]{2}{*}{ Date. } & \multirow[b]{2}{*}{ Obs'r. } & \multirow[b]{2}{*}{ Temp. } & \multirow[b]{2}{*}{$\eta$} & \multirow[b]{2}{*}{$i_{1}-c$} & \multirow[b]{2}{*}{$\tilde{5}$} & \multicolumn{2}{|c|}{$c$} & \multirow[b]{2}{*}{$\varepsilon \cos \varphi$} & \multirow{2}{*}{$\begin{array}{c}e \cos \varphi \\
\text { from } \\
\text { Stars. }\end{array}$} & \multirow{2}{*}{$\begin{array}{c}e \\
\text { from } \\
\text { Coll's. }\end{array}$} \\
\hline & & & & & & $\begin{array}{l}\text { From } \\
\text { Stars. }\end{array}$ & $\begin{array}{l}\text { From } \\
\text { Coll's. }\end{array}$ & & & \\
\hline I 898 & & $\circ$ & 'I & $\prime \prime$ & "' & 11 & $\prime \prime$ & $\prime \prime$ & $\prime \prime$ & $\prime \prime$ \\
\hline $\begin{array}{c}\text { Nov. } 27 \\
1899\end{array}$ & $\mathrm{Br}$. & . & +104 & . & -76 & $\cdots$ & $\ldots$ & $\ldots$ & $\ldots$ & . \\
\hline$\underset{\text { I }}{\text { Apr. I }} 5$ & $\mathrm{Br}$. & . & +87 & . & -64 & - $\quad \cdots$ & $\cdots$ & $\cdots$ & $\ldots$ & . \\
\hline Feb. 6 & See & . & . & . & -68 & $\ldots$ & $\cdots$ & $\cdots$ & -1.3 & . \\
\hline 27 & See & . & +113 & . & . & $\ldots$ & $\ldots$ & $\ldots$ & $\ldots$ & . \\
\hline May 4 & See & . & +112 & . & . & $\ldots$ & $\cdots$ & $\ldots$ & $\cdots$ & . \\
\hline I3 & See & . & + II 9 & . & . & $\ldots$ & $+\mathrm{I} 8^{*}$ & $\cdots$ & $\cdots$ & . \\
\hline $1902^{14}$ & See & . & +116 & . & . & $\cdots$ & $+116 *$ & $\cdots$ & $\ldots$ & . \\
\hline July $\quad 13$ & Fk. & $69 \mathrm{~F}$ & + II 6 & -54 & $-7 \mathrm{I}$ & $\cdots$ & $\cdots$ & $\cdots$ & $\cdots$ & - \\
\hline 27 & Fk. & 76 & $+\operatorname{Ir} 3$ & -55 & -73 & $\cdots$ & $\cdots$ & $\cdots$ & $\cdots$ & $\cdots$ \\
\hline Aug. 3 & $\mathrm{Fk}$. & 80 & +II 5 & $-5 \mathrm{I}$ & -73 & $\cdots$ & $\cdots$ & $\cdots$ & $\cdots$ & - \\
\hline I I & $\mathrm{Fk}$ & 70 & +115 & -55 & -75 & $\cdots$ & $\cdots$ & $\cdots$ & $\cdots$ & $\cdots$ \\
\hline 28 & $\mathrm{Fk}$. & 67 & +121 & -55 & -74 & $\ldots$ & $\ldots$ & $\cdots$ & $\cdots$ & - \\
\hline Sept. 23 & Fk. & 70 & +115 & $-5^{2}$ & -73 & $\ldots$ & +113 & $\ldots$ & $\ldots$ & . \\
\hline Oct. $\quad 22$ & Fk. & $5^{\mathrm{I}}$ & $+\mathrm{rin} 6$ & $-5^{2}$ & -73 & +114 & $\cdots$ & +94 & $\cdots$ & $\because$ \\
\hline$\quad 27$ & $\mathbf{F k}$ & 64 & $\ldots$ & . & . & $\ldots$ & $\operatorname{tin} 3$ & $\ldots$ & $\cdots$ & tro \\
\hline Nov. 5 & Fk. & $5^{6}$ & $\ldots$ &,$\quad \cdots$ & . & $\ldots$ & $\ldots$ & $\cdots$ & $\cdots$ & +4 \\
\hline $1903^{28}$ & Fk. & 35 & + I 6 & $-5^{2}$ & -68 & +107 & +108 & $\ldots$ & $\cdots$ & . \\
\hline Jan. 9 & $\mathrm{Fk}$. & 27 & $\ldots$ & . & . & $+\operatorname{Ir} 3$ & +119 & +96 & +2 & -2 \\
\hline 9 & $\mathrm{Fk}$ & 20 & +114 & -57 & -67 & $\because$ & $\cdots$ & $\ldots$ & . & . \\
\hline Feb. & $\mathrm{Fk}$. & 14 & +III & -56 & -63 & +115 & $\cdots$ & +95 & +4 & . \\
\hline Mar. $\quad 13$ & Fk. & 55 & +114 & -50 & -70 & $\cdots$ & $\cdots$ & $\ldots$ & $\ldots$ & . \\
\hline Apr. $\quad 2 \mathrm{I}$ & $\mathrm{Fk}$. & 48 & $+\mathrm{I} 13$ & -55 & -65 & +113 & $\cdots$ & +98 & +6 & . \\
\hline June $2 \mathrm{I}$ & Fk. & 70 & +113 & -53 & -74 & $+\mathrm{II} 4$ & $\cdots$ & +96 & +5 & .. \\
\hline $\begin{array}{c}\text { Oct. I3 } \\
1904\end{array}$ & Fk. & 60 & $\operatorname{lin} 4$ & -55 & -72 & $\ldots$ & $\ldots$ & $\cdots$ & $\ldots$ & $\cdots$ \\
\hline Feb. $\quad 3$ & Fk. & 24 & $+\operatorname{II} 3$ & -57 & $-6 I$ & $\ldots$ & $\cdots$ & $\ldots$ & $\ldots$ & . \\
\hline May 7 & $\mathrm{~F} \mathrm{k}$ & 65 & $+\operatorname{II} 5$ & -53 & -72 & $\operatorname{tIII}$ & $\cdots$ & +92 & +7 & . \\
\hline $\begin{array}{l}\text { Oct: } \\
\text { 1905 }\end{array}$ & Hd. & 66 & $+\ln 5$ & $-5^{2}$ & -63 & $\ldots$ & $\cdots$ & $\ldots$ & $\cdots$ & . \\
\hline May 20 & Hd. & 57 & tiri & -54 & $-6 r$ & $\ldots$ & $\cdots$ & . & $\cdots$ & . \\
\hline June $\quad 5$ & Hd. & 76 & t III & -55 & -62 & +116 & $\ldots$ & +104 & +4 & . \\
\hline Nov. I I & $\mathrm{Hd}$. & 43 & +112 & -53 & -65 & + 112 & $\cdots$ & +93 & +5 & . \\
\hline
\end{tabular}

* Determined on May 20 and May 21, I90r, respectively. 
The torsion of the telescope tube, $f$, was determined by Mr. FREDERICK from levels placed on the micrometer box, with the following results:

\begin{tabular}{|c|c|c|c|c|c|c|c|c|}
\hline Date. & Temp. & $f$ & Date. & Temp. & $f$ & Date. & Temp. & $f$ \\
\hline 1903 & $\circ$ & ○ & 1903 & 。 & $\circ$ & 1903 & 0 & 0 \\
\hline May 5 & . & $+0.02 \mathrm{I}$ & July $\mathrm{I}_{3}$ & $74 \mathrm{~F}$ & +0.022 & July 24 & $72 \mathrm{~F}$ & +0.017 \\
\hline 26 & $64 \mathrm{~F}$ & +0.023 & I3 & 75 & +o.or 3 & I904 & & \\
\hline June 25 & 70 & +o. OI 7 & 24 & 72 & +o.014 & May 8 & 6.5 & +0.020 \\
\hline 26 & 68 & +o. or 6 & & & & 8 & 65 & +0.015 \\
\hline
\end{tabular}

These results show no appreciable change in the constants due to changes of temperature. The values adopted by Mr. FREDERICK for the coinputation of his tables are:

$$
\begin{aligned}
\eta & =+\mathrm{Ir} 5 \\
\xi & =-72 \\
c & =+\mathrm{II} 3 \\
i_{1} & =+59 \\
e \cos \varphi & =+5 \\
f & =+0^{\circ} .018
\end{aligned}
$$

By means of these tables all observations made after January I, I902, have been corrected for the effect of the constants. Prior to I902 no such corrections have been applied to the observations printed in this volume.

\section{THE I2-INCH EQUATORIAL.}

The objective.-The 9.6-inch objective which was used with this instrument until December I9, I895, was made by MERZ \& MAHLER, of Munich. Its aperture and focal length, as given in the Washington Astronomical Observations for I874, Volume XXI, Appendix I, are respectively 9.62 inches and $\mathrm{I} 4$ feet 4.5 inches.

The I2-inch objective which has been in use since the above date, was made by Alvan Clark and Sons. It is of the Fraunhofer-Hershel form and its curves were specially computed by Prof. Wili,IAM HARKNEss, U. S. N., from the refractive indices of the hard crown and dense flint glasses of which its lenses were made. Its clear aperture is $\mathrm{I}$. 98 inches, and the distance from the front surface of the crown lens to the focal plane is 180.6 inches.

The column.-The column is of cast-iron and its base, which measures 6 feet 6 inches on the north and south line by 5 feet on the east and west, is rigidly bolted to the masonry pier. It rises to a height of ro feet above the cap-stone and 8 feet above the floor of the observing room. It is circular in section except at the top and bottom and tapers slightly from the base upward, the diameter of a section in the center being about $x 6$ inches. The top of the column which supports the head is $x 8$ inches square.

There are two glass doors, one on the east and one on the west side of the column, for access to the driving clock which is located within the section. Another opening on the east side near the floor affords access to the weights of the driving clock. 


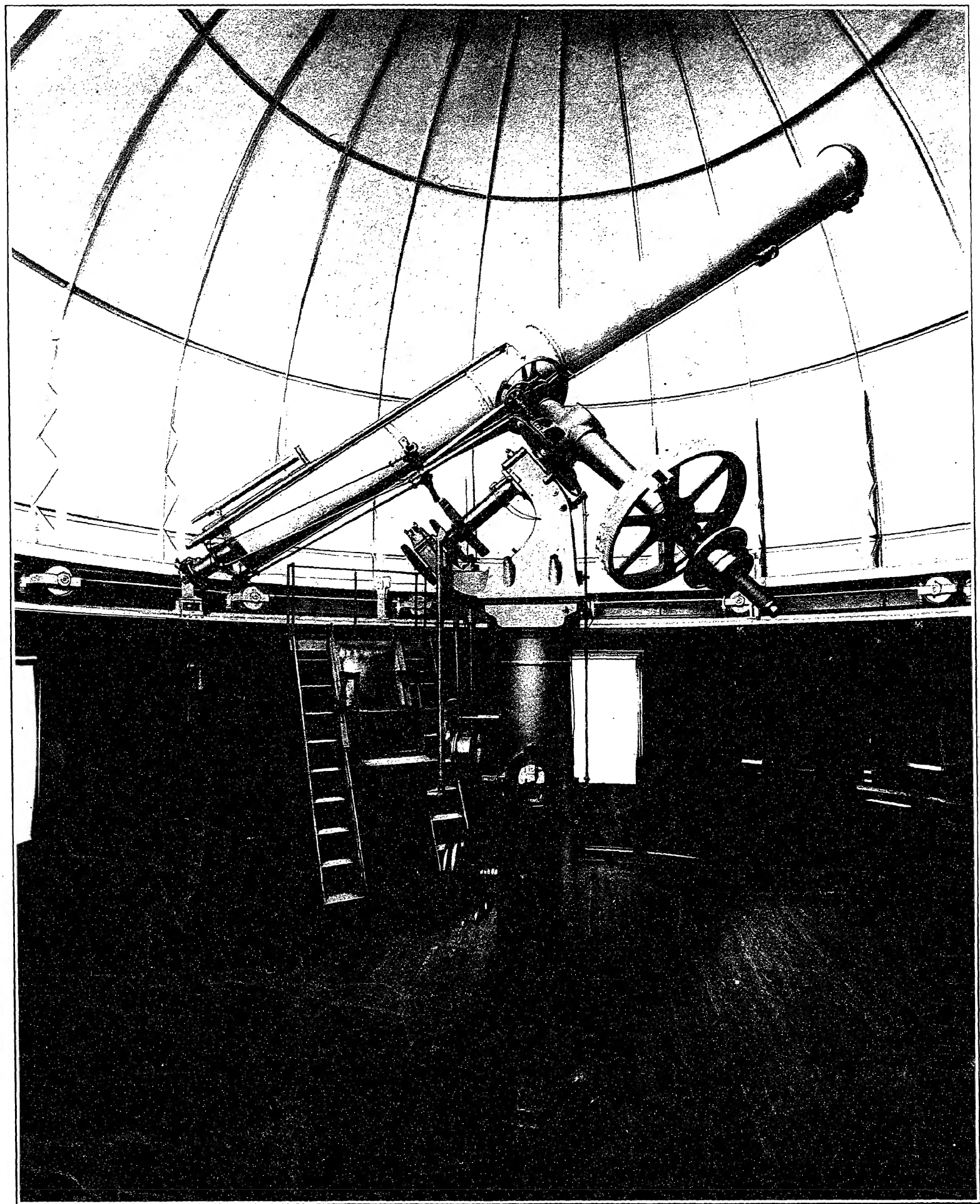

THE 12-INCH EQUATORIAL. 
The equatorial head.-The equatorial head consists of a single casting of great solidity carrying the polar axis and its attachments. It is provided with means for adjustments in altitude and azimuth.

The axes.-The polar and declination axes are of hand-forged steel, with the friction in the bearings and the end thrust relieved by antifriction mechanism.

The tube.- The tube is made up of eight sections of hard rolled sheet steel, except the central section, which is of cast steel, for attachment to the declination axis. These sections are solidly riveted together, and the tube has a taper each way from the center. The diameter of the tube is $I_{5}$ inches at the center and $I_{2}$ inches at the ends. Its length, not including the draw tube; is I4 feet.

During the fiscal year ending June 30, I897, the diaphragms in the tube were replaced by ones of larger aperture to prevent cutting off the outer edge of the field of view of the low power HUYGENIAN eyepieces.

The circles. - The fine reading circles in hour angle and declination are graduated on silver to $30^{s}$ and $5^{\prime}$, respectively. The least readings of the verniers are $\mathrm{I}^{\mathrm{s}}$ in hour angle and $\mathrm{IO}^{\prime \prime}$ in declination.

The hour circle is read by two microscopes, located on the south side of the column at a convenient height above the floor. The declination circle is read at the eye-end by means of two microscopes attached to the tube. In December, I896, new objectives were placed in these microscopes by M. E. KAHLER, as the old ones gave very bad definition on account of excessive spherical aberration.

The instrument also has coarse circles in both hour angle and declination and a dial which indicates directly the setting in right ascension and declination.

The finder.-The finder is attached to the side of the tube opposite the declination axis. The one, used at first with this instrument, was taken from the 9.6-inch equatorial. It has an aperture of 2.6 inches and a focal length of 32 inches, and carries an eyepiece magnifying 20 diameters.

This was replaced in August, I905, by one made by John CLAcEY, of Glendale, Maryland, which has an aperture of $4 \frac{1}{16}$ inches and a focal length of $46 \frac{1}{2}$ inches. It has an eyepiece, magnifying 35 diameters and a field of view of $\mathrm{I}^{\circ} 3 \mathrm{O}^{\prime}$

A direct vision spectroscope is also provided for the instrument.

The driving clock.-The driving clock, which is located within the cast-iron column, has a double conical pendulum and is driven by a weight which is wound up by hand. The motion of the clock is communicated to the polar axis by a continuous worm gear. Extra gears are provided for changing from a sidereal to a mean solar or a mean lunar rate.

The clock is entirely too small to control a telescope of this size. A new and slightly heavier pendulum was made for it in I904 by Mr. DinwidDie. This improved the driving of the clock, but it is still unsatisfactory.

Other details.-The clamps and slow motions in right ascension and declination are operated from the eye-end of the telescope and are on the same side of the tube as the declination axis.

Rapid motion is given to the telescope by means of two hand wheels located on the south side of the column and connected by gearing with the axes of the instrument. 
The building and pier.-The equatorial is located in the west end of the main building, as shown by PLATE IX. The masonry pier which supports the instrument is constructed of hard pressed brick and rests on a solid concrete foundation 20 feet square. From the concrete foundation, which is about 4 feet below the basement floor to the level of the first floor, the pier is in the form of a frustum of a pyramid. The base of the frustum is $\mathrm{I} 3$ feet 8 inches square and the top is II feet 6 inches square. From the first floor to the top the pier has the form of a frustum of a cone, the diameter of the base being Io feet and the top 9 feet. The total height of the pier above the concrete foundation is 58 feet 9 inches and above the ground 46 feet 6 inches. It is hollow from the basement floor to a point about 4 feet from the top.

The pier is 172 feet south and 276 feet east of the center of the clock room, which determines the latitude and longitude of this observatory.

The dome.-The steel dome was made by The WARnER and SwASEy Company, and is similar in construction to the large dome for the 26 -inch equatorial. It is 26 feet in diameter with a slit 3 feet wide running from the base to a point a little beyond the zenith. The clear aperture of the slit when the shutters are opened to the widest extent is 2 feet 7 inches, which is too narrow an opening for an instrument of this size.

There are I 4 sets of wheels, 3 in each set, which carry the dome on the circular track. These sets of wheels are equally spaced about the track and are rigidly connected by rods. The diameter of the inner wheels is ro inches. The dome is turned by a hand rope.

Cork paint has been applied to the inner surface of the dome to prevent moisture condensing on it and dripping on the instrument and floor.

Illumination of the instrument.-A I IO-volt commercial lighting circuit is used for illuminating the circles and the micrometer. A set of contact springs on the polar axis and another on the declination axis serve to convey the current from the column to the eye-end of the instrument. A third set of springs on the micrometer carries the current to the lamps of the micrometer. All the lamps on the instrument are 20 -volt and 2 candle-power. The two which illuminate the hour circle are in series and are controlled by a switch on the south side of the column. The two which illuminate the declination circle and the two which illuminate the micrometer threads are in series by pairs on separate circuits and controlled by a two-point switch on the telescope tube at the eye-end.

There is no arrangement for bright field illumination for this instrument.

The micrometer. - The micrometer was made by G. N. SAEGMÜLLER, formerly of Washington, D. C. It has five fixed longitudinal threads for measuring differences in right ascension by transits. These threads are 0.12 inch apart, corresponding to an equatorial interval of about $9^{\mathrm{s}}$.I for the 2 -inch objective and $9^{\mathrm{s}} \cdot 5$ for the $9 \cdot 6$-inch.

At right angles to this set of threads is a fixed transverse thread and five movable threads carried on a slide attached to the micrometer screw. If the latter threads be designated as I, II, III, IV, and V in order from the head of the screw, then the 


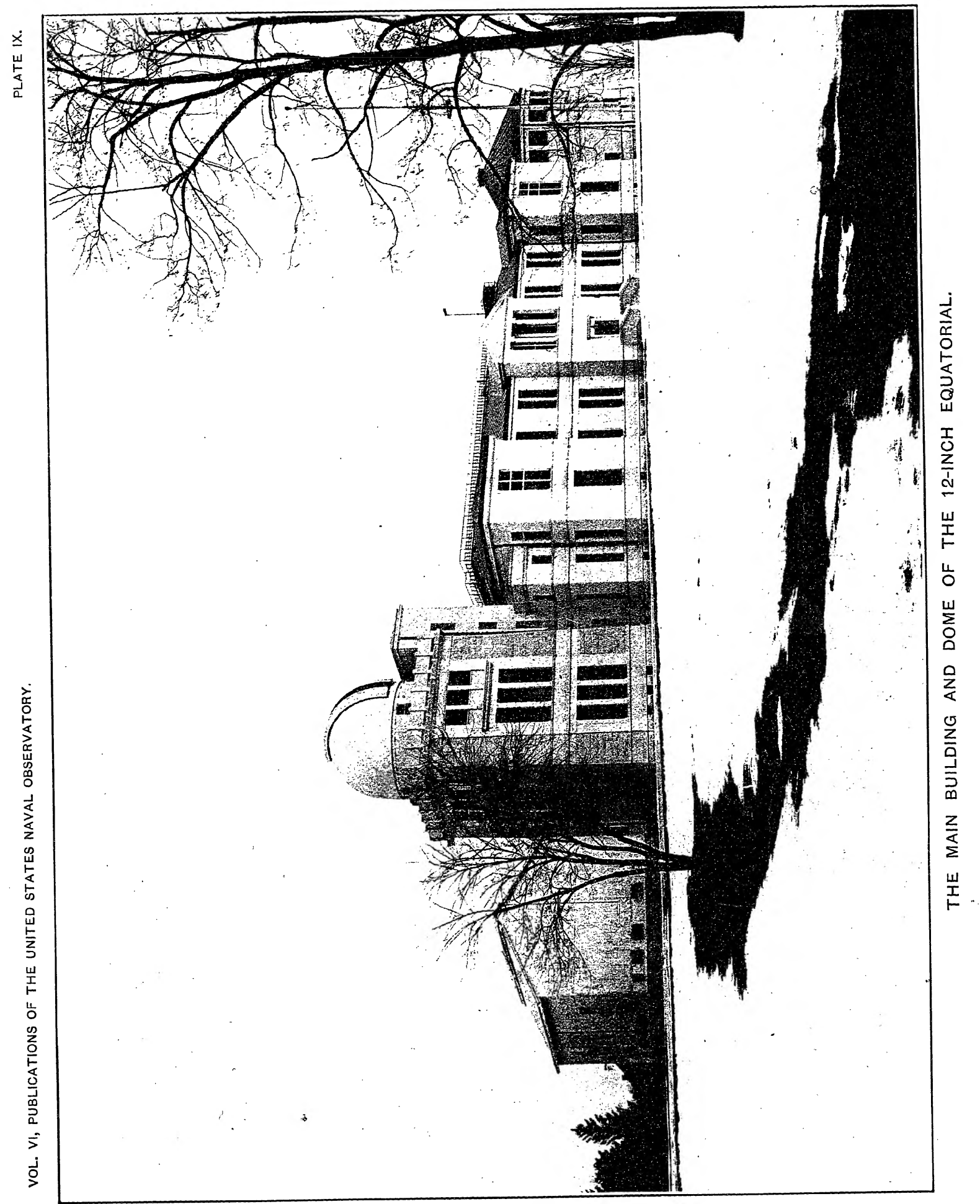


approximate distances between them and the corresponding intervals for the two objectives are as follows:

\begin{tabular}{|c|c|c|c|}
\hline \multirow{2}{*}{ Threads. } & \multirow{2}{*}{ Distance. } & \multicolumn{2}{|c|}{ Interval. } \\
\hline & & I 2 -inch. & 9.6-inch. \\
\hline & in & " & "' \\
\hline I-II & o. 18 & 206 & 215 \\
\hline II-III & 0.24 & 276 & 289 \\
\hline III-IV & 0.24 & 276 & 289 \\
\hline$I V-V$ & o. 18 & 206 & 215 \\
\hline
\end{tabular}

The illumination of the threads is at present effected by two small 20-volt and 2 candle-power lamps, one lamp for each set of threads. The intensity of the illumination can be varied by changing the width of the slit through which the light is admitted.

The micrometer screw was investigated for progressive and periodic errors by Assistant MATT FREDERICKSON in June, I908. This investigation was made with the Ruled Glass Scale Comparator, and in this case each quarter revolution of the micrometer screw was measured with the same part of the screw A of the comparator. The results are given in TABLES X, XI. One,revolution of Micrometer A corresponds to $\mathrm{I}^{\prime \prime} .056$.

TABLE X.-Showing Inequalities in the Whole Revolutions.

\begin{tabular}{|c|c|c|c|c|c|c|c|c|c|c|c|}
\hline \multicolumn{2}{|c|}{ Micrometer } & \multirow{2}{*}{$\begin{array}{c}\text { Residu- } \\
\text { als from } \\
\text { Mean. }\end{array}$} & \multicolumn{2}{|c|}{ Micrometer } & \multirow{2}{*}{$\begin{array}{l}\text { Residu- } \\
\text { als from } \\
\text { Mean. }\end{array}$} & \multicolumn{2}{|c|}{ Micrometer } & \multirow{2}{*}{$\begin{array}{l}\text { Residu- } \\
\text { als from } \\
\text { Mean. }\end{array}$} & \multicolumn{2}{|c|}{ Micrometer } & \multirow{2}{*}{$\begin{array}{l}\text { Residu- } \\
\text { als from } \\
\text { Mean. }\end{array}$} \\
\hline $\begin{array}{l}\text { Saeg- } \\
\text { müller. }\end{array}$ & A. & & $\begin{array}{l}\text { Saeg- } \\
\text { müller. }\end{array}$ & A. & & $\begin{array}{l}\text { Saeg- } \\
\text { müller. }\end{array}$ & A. & & $\begin{array}{l}\text { Saeg- } \\
\text { müller. }\end{array}$ & A. & \\
\hline rev. & rev. & 11 & rev. & rev. & "' & rev. & rev. & " & rev. & rev. & "I \\
\hline $5-6$ & 21.635 & +o. 039 & I5-I 6 & $2 x .65^{8}$ & +o.or 5 & $25-26$ & 21.692 & -0.021 & $35-36$ & 21.690 & -0.019 \\
\hline $6-7$ & 21.642 & +0.032 & I6-I7 & 21.672 & 0.000 & $26-27$ & 21.687 & -о.016 & $36-37$ & $2 \mathrm{r} .688$ & -0.017 \\
\hline $7-8$ & 21.656 & +o.or 7 & I $7-18$ & 21.650 & +o. 023 & $27-28$ & 21.682 & -0.011 & $37-38$ & $2 x .685$ & -0.014 \\
\hline $8-9$ & 21.653 & +o. 020 & I $8-19$ & 21.665 & +0.007 & $28-29$ & 21.664 & +0.008 & $3^{8-39}$ & 21.702 & -0.032 \\
\hline 9-10 & 21.628 & +0.046 & I9-20 & 21.660 & +o.or3 & $29-30$ & 21.672 & 0.000 & $39-40$ & 21.698 & -0.027 \\
\hline ro-II & 21.645 & +0.028 & $20-2 \mathrm{I}$ & $2 \mathrm{I} .68 \mathrm{I}$ & -0.010 & $30-3 I$ & 21.666 & +o. 006 & $40-4 \mathrm{I}$ & 21.695 & -0.024 \\
\hline $\mathrm{II}-\mathrm{I} 2$ & 21.664 & +0.008 & $2 I-22$ & 21.668 & +o. 004 & $3 x-32$ & 21.677 & -0.005 & $4 I-42$ & 21.688 & -0.017 \\
\hline $12-13$ & 21.658 & fo. 015 & $22-23$ & 21.669 & +o. 003 & $32-33$ & 21.678 & -0.006 & $42-43$ & 2 x. 683 & -0.012 \\
\hline $13-14$ & 21.665 & +0.007 & $23-24$ & $2 \mathrm{x} .645$ & +o. 028 & $33-34$ & $2 \mathrm{I} .680$ & -0.008 & $43-44$ & 21.692 & $-0.02 \mathrm{I}$ \\
\hline $14-15$ & 21.660 & +o.or3 & $24-25$ & 2 r. 675 & -0.003 & $34-35$ & 21.697 & -0.026 & $44-45$ & 21.705 & -0.035 \\
\hline
\end{tabular}

The excess of positive residuals in the first part of the screw and of negative residuals in the last part indicates either a small progressive error in the screw of this micrometer or a slight change in the comparator during the course of the investigation. If any progressive error exists in the micrometer screw, it is too small to affect appreciably any measurements made with it. 
TABLE XI.-Showing the Inequalities in the Quarter Revolutions.

\begin{tabular}{|c|c|c|c|c|c|c|c|c|}
\hline \multirow{2}{*}{$\begin{array}{l}\text { Saeg- } \\
\text { müller } \\
\text { Microm. }\end{array}$} & \multirow{2}{*}{$\begin{array}{c}\text { First } \\
\text { Quarter. }\end{array}$} & \multirow{2}{*}{$\begin{array}{l}\text { Second } \\
\text { Quarter. }\end{array}$} & \multirow{2}{*}{$\begin{array}{c}\text { Third } \\
\text { Quarter. }\end{array}$} & \multirow{2}{*}{$\begin{array}{l}\text { Fourth. } \\
\text { Quarter. }\end{array}$} & \multicolumn{4}{|c|}{ Residuals from Mean. } \\
\hline & & & & & $\begin{array}{c}\text { First } \\
\text { Quarter. }\end{array}$ & $\begin{array}{l}\text { Second } \\
\text { Quarter. }\end{array}$ & $\begin{array}{l}\text { Third } \\
\text { Quarter. }\end{array}$ & $\begin{array}{l}\text { Fourth } \\
\text { Quarter. }\end{array}$ \\
\hline rev. & rev. & rev. & rev. & rev. & $\prime \prime$ & $\prime \prime$ & $\prime \prime$ & $\prime \prime$ \\
\hline $5-6$ & $5 \cdot 4$ I 5 & $5 \cdot 388$ & $5 \cdot 425$ & $5 \cdot 396$ & -0.010 & +o. or9 & -0.020 & +o. OII \\
\hline $6-7$ & $5 \cdot 430$ & $5 \cdot 396$ & $5 \cdot 405$ & $5 \cdot 4 \mathrm{OI}$ & -0.025 & to. OII & +o. OOI & +o. 005 \\
\hline $7-8$ & $5 \cdot 392$ & $5 \cdot 379$ & $5 \cdot 422$ & $5 \cdot 377$ & +o. 014 & +o. 028 & -0.017 & +o. 031 \\
\hline $8-9$ & $5 \cdot 400$ & $5 \cdot 374$ & $5 \cdot 384$ & $5 \cdot 3^{89}$ & +o. 006 & +o. 034 & +0.023 & +o. o1 8 \\
\hline $9-10$ & $5 \cdot 370$ & $5 \cdot 353$ & $5 \cdot 435$ & $5 \cdot 408$ & +o. 038 & +0.056 & $-0.03 I$ & -0.002 \\
\hline IO-1I & $5 \cdot 378$ & $5 \cdot 364$ & $5 \cdot 467$ & $5 \cdot 419$ & +o. 030 & +o. 044 & -0.064 & -0.014 \\
\hline I I -12 & $5 \cdot 380$ & $5 \cdot 386$ & $5 \cdot 423$ & $5 \cdot 410$ & +0.027 & $+0.02 x$ & -0.018 & -0.004 \\
\hline $12-13$ & $5 \cdot 4 \mathrm{I} 8$ & $5 \cdot 384$ & $5 \cdot 430$ & $5 \cdot 384$ & -0.013 & +0.023 & -0.025 & +0.023 \\
\hline $13-14$ & $5 \cdot 370$ & $5 \cdot 365$ & $5 \cdot 438$ & $5 \cdot 365$ & +o. 038 & +o. 043 & -0.034 & to. 043 \\
\hline $14-15$ & $5 \cdot 36 \mathrm{I}$ & $5 \cdot 37^{8}$ & $5 \cdot 408$ & $5 \cdot 435$ & +0.047 & +o.030 & -0.002 & $-0.03 I$ \\
\hline I $5-16$ & 5.404 & $5 \cdot 3^{84}$ & $5 \cdot 435$ & $5 \cdot 39^{8}$ & +0.002 & +o. 023 & $-0.03 \mathrm{I}$ & +o. 008 \\
\hline $16-17$ & $5 \cdot 3^{8} 3$ & $5 \cdot 405$ & $5 \cdot 406$ & $5 \cdot 4 \mathrm{IO}$ & +o. 024 & to. oor & o. 000 & -0.004 \\
\hline $17-18$ & $5 \cdot 406$ & $5 \cdot 392$ & $5 \cdot 413$ & $5 \cdot 43 \mathrm{I}$ & o. 000 & +o.015 & -0.007 & -0.026 \\
\hline $18-19$ & $5 \cdot 400$ & $5 \cdot 390$ & $5 \cdot 4 \mathrm{I} 8$ & $5 \cdot 387$ & +o. 006 & to.017 & -0.013 & +0.020 \\
\hline $19-20$ & 5.435 & $5 \cdot 37 \mathrm{I}$ & $5 \cdot 420$ & $5 \cdot 398$ & $-0.03 \mathrm{I}$ & +o. 037 & -0.015 & +o. 008 \\
\hline $20-2 \mathrm{I}$ & $5 \cdot 408$ & $5 \cdot 385$ & $5 \cdot 408$ & $5 \cdot 388$ & -0.002 & +0.022 & -0.002 & to. org \\
\hline $2 I-22$ & $5 \cdot 426$ & $5 \cdot 39 x$ & $5 \cdot 406$ & $5 \cdot 400$ & $-0.02 \mathrm{I}$ & to. or6 & o. 000 & +o. 006 \\
\hline $22-23$ & $5 \cdot 4 \mathrm{I} 5$ & $5 \cdot 378$ & $5 \cdot 414$ & $5 \cdot 426$ & - o. oIo & to. 030 & -0.008 & -0.021 \\
\hline $23-24$ & $5 \cdot 4 \mathrm{I} 3$ & $5 \cdot 393$ & $.5 \cdot 433$ & $5 \cdot 405$ & -0.007 & +o. or 4 & -0.028 & to. 001 \\
\hline $24-25$ & $5 \cdot 410$ & 5.403 & 5.403 & $5 \cdot 417$ & -0.004 & +o. 003 & +0.003 & -0.012 \\
\hline $25^{-26}$ & $5 \cdot 400$ & 5.409 & 5.403 & $5 \cdot 422$ & +0.006 & -0.003 & +0.003 & -0.017 \\
\hline $26-27$ & $5.4 \mathrm{II}$ & $5 \cdot 406$ & 5.418 & $5 \cdot 425$ & -0.005 & 0.000 & -0.013 & -0.020 \\
\hline $27-28$ & $5 \cdot 393$ & 5.379 & $5 \cdot 435$ & 5.427 & to.014 & +0.028 & $-0.03 \mathrm{I}$ & -0.022 \\
\hline $28-29$ & $5 \cdot 4 \mathrm{I} 7$ & $5.37 x$ & $5 \cdot 436$ & $5 \cdot 418$ & -0.012 & +0.037 & -0.032 & -0.013 \\
\hline $29-30$ & $5 \cdot 410$ & $5 \cdot 385$ & $5 \cdot 43^{8}$ & $5 \cdot 418$ & -0.004 & +0.022 & -0.034 & -0.013 \\
\hline $30-3 I$ & $5 \cdot 424$ & $5 \cdot 38 \mathrm{I}$ & $5 \cdot 4 \mathrm{I} 4$ & $5 \cdot 409$ & -0.019 & +0.026 & -0.008 & -0.003 \\
\hline $31-32$ & 5.407 & $5 \cdot 404$ & $5 \cdot 4^{23}$ & $5 \cdot 410$ & -0.001 & +0.002 & -0.018 & -0.004 \\
\hline $32-33$ & $5 \cdot 408$ & $5 \cdot 396$ & $5 \cdot 427$ & $5 \cdot 406$ & -0.002 & +o. OII & -0.022 & 0.000 \\
\hline $33-34$ & $5 \cdot 406$ & 5.410 & $5 \cdot 430$ & $5 \cdot 408$ & 0.000 & -0.004 & -0.025 & -0.002 \\
\hline $34-35$ & $5 \cdot 399$ & $5 \cdot 392$ & 5.402 & $5 \cdot 430$ & +0.007 & to. or 5 & to. 004 & -0.025 \\
\hline $35-36$ & $5 \cdot 4 \mathrm{IO}$ & $5 \cdot 4 \mathrm{IO}$ & $5 \cdot 4 \mathrm{II}$ & $5 \cdot 415$ & -0.004 & -0.004 & -0.005 & -0.009 \\
\hline $36-37$ & $5 \cdot 4^{18}$ & $5 \cdot 40 \mathrm{I}$ & $5 \cdot 4$ I 5 & $5 \cdot 418$ & -0.013 & +0.005 & -0.010 & -0.013 \\
\hline $37-38$ & 5.427 & $5 \cdot 3^{80}$ & $5 \cdot 424$ & $5 \cdot 40 \mathrm{I}$ & -0.022 & +0.027 & -0.019 & +o. 005 \\
\hline $3^{8-39}$ & $5 \cdot 427$ & $5 \cdot 398$ & $5 \cdot 424$ & $5 \cdot 428$ & -0.022 & +0.008 & -0.019 & -0.023 \\
\hline $39-40$ & $5 \cdot 4 \mathrm{I} 4$ & $5 \cdot 388$ & $5 \cdot 43^{\circ}$ & $5 \cdot 4 \mathrm{II}$ & -0.008 & to. o19 & -0.025 & -0.005 \\
\hline $40-4 I$ & $5 \cdot 405$ & $5 \cdot 40 \mathrm{I}$ & $5 \cdot 42 \mathrm{I}$ & $5 \cdot 408$ & +o. oor & +o. 005 & -o.016 & -0.002 \\
\hline $4 I-42$ & 5.410 & $5 \cdot 395$ & $5 \cdot 423$ & $5 \cdot 405$ & -0.004 & +0.012 & -0.018 & +o. 001 \\
\hline $4^{2-43}$ & $5 \cdot 406$ & $5 \cdot 3^{8} 3$ & $5 \cdot 432$ & $5 \cdot 401$ & o. 000 & +0.024 & -0.027 & +o. 005 \\
\hline $43-44$ & $5 \cdot 404$ & $5 \cdot 388$ & $5 \cdot 420$ & $5 \cdot 429$ & +0.002 & +o.019 & -0.015 & -0.024 \\
\hline $44-45$ & $5 \cdot 397$ & $5 \cdot 400$ & $5 \cdot 45^{\circ}$ & $5 \cdot 402$ & +o. 009 & +o. 006 & -0.046 & +o. 004 \\
\hline
\end{tabular}

The mean of the residuals for the first quarter is $\ldots \ldots \ldots \ldots \ldots \ldots \ldots+o^{\prime \prime} .0008$

The mean of the" residuals for the second quarter is $\ldots \ldots \ldots \ldots \ldots \ldots+o^{\prime \prime}$. or 85

The mean of the residuals for the third quarter is ..............

The mean of the residuals for the fourth quarter is .............. $-o^{\prime \prime} .0025$ 
This gives as the formula for periodic errors:

$$
\varphi(u)=-\mathrm{o}^{\prime \prime} .0096 \cos u-\mathrm{o}^{\prime \prime} .0009 \sin u+\mathrm{o}^{\prime \prime} .0040 \cos 2 u \text {. }
$$

The periodic errors, as well as the progressive errors, are small, and the screw is an excellent one in every respect.

This micrometer screw has 50 threads to the inch. There have been several determinations of the value of one revolution, and the different values adopted and used in the reduction of the observations published in this volume are as follows:

\begin{tabular}{|c|c|c|c|c|}
\hline Period for which adopted. & $\begin{array}{c}\text { Value of } \\
\text { One Revo- } \\
\text { lution. }\end{array}$ & Observer. & Objective. & Remarks. \\
\hline From Oct. Io, 1894, to Dec. 3 , I 895 & $23 \cdot 872$ & F. & 9. 6-inch & $\begin{array}{l}\text { From transits of circumpolar } \\
\text { stars. }\end{array}$ \\
\hline $\begin{array}{l}\text { From Feb. } 21,1896 \text {, to Apr. I7, } \\
\text { 1899. }\end{array}$ & 22.7714 & F. & I 2-inch & $\begin{array}{l}\text { From transits of circumpolar } \\
\text { stars. }\end{array}$ \\
\hline $\begin{array}{l}\text { From July I7, I899, to Oct. } 29 \text {, } \\
\text { I900. }\end{array}$ & 22.8876 & See & I 2-inch & $\begin{array}{l}\text { From differences of declinations } \\
\text { of stars in the Pleiades and } \\
\text { from transits of circumpolar } \\
\text { stars. }\end{array}$ \\
\hline $\begin{array}{l}\text { From Apr. } 27 \text {, 1901, to Dec. } 31 \text {, } \\
\text { 1907. }\end{array}$ & 22.8944 & See and $\mathrm{Hd}$. & I 2-inch & $\begin{array}{l}\text { A mean of SEE'S previous value } \\
\text { and a value by HAMMOND from } \\
\text { transits of circumpolar and } \\
\text { equatorial stars. }\end{array}$ \\
\hline
\end{tabular}

The position circle.-The position circle, by SAEGMÜLLER, is $7 \frac{\mathrm{x} / 4}{4}$ inches in diameter, and is graduated to half degrees. It is read by two verniers, designated by $\mathrm{A}$ and $\mathrm{B}$, the least reading being $\mathrm{O}^{\circ} .02$.

The following readings of the two verniers for the eccentricity of the position circle were made by J. C. HAmmond in June, I9o8:

\begin{tabular}{|c|c|c|c|c|c|c|c|c|c|c|c|}
\hline $\begin{array}{l}\text { Vernier } \\
\text { A. }\end{array}$ & $\begin{array}{c}\text { Vernier } \\
\text { B. }\end{array}$ & $\begin{array}{r}\mathrm{A}-\mathrm{B} \\
+\mathrm{I} 80^{\circ}\end{array}$ & $\begin{array}{c}\text { Vernier } \\
\text { A. }\end{array}$ & $\begin{array}{c}\text { Vernier } \\
\text { B. }\end{array}$ & $\begin{array}{r}\mathrm{A}-\mathrm{B} \\
+180^{\circ}\end{array}$ & $\begin{array}{c}\text { Vernier } \\
\text { A. }\end{array}$ & $\begin{array}{c}\text { Vernier } \\
\text { B. }\end{array}$ & $\begin{array}{c}\mathrm{A}-\mathrm{B} \\
+180^{\circ}\end{array}$ & $\begin{array}{c}\text { Vernier } \\
\text { A. }\end{array}$ & $\begin{array}{c}\text { Vernier } \\
\text { B. }\end{array}$ & $\begin{array}{c}\mathrm{A}-\mathrm{B} \\
+180^{\circ}\end{array}$ \\
\hline$\circ$ & $\circ$ & $\circ$ & $\circ$ & $\circ$ & $\circ$ & $\circ$ & $\circ$ & $\circ$ & $\circ$ & $\circ$ & $\circ$ \\
\hline 0.00 & I 79.96 & +o. 04 & 90.00 & $269 \cdot 98$ & +o. 02 & I 80.00 & o. oo & 0.00 & 270.00 & $90.0 \mathrm{I}$ & -0.01 \\
\hline 5.00 & I 84.96 & +o. 04 & 95.00 & 274.99 & to. oI & 185.00 & 5.00 & 0.00 & 275.00 & 95.01 & -0.01 \\
\hline Io. 00 & r89. 96 & +o. 04 & 100.00 & 279.98 & +0.02 & 190.00 & I0. 00 & 0.00 & 280.00 & 100. OI & -0.01 \\
\hline 15.00 & I94. 97 & +0.03 & 105.00 & 284.98 & +o. 02 & 195.00 & 15.00 & 0.00 & 285.00 & 105.01 & -0.01 \\
\hline 20.00 & 199.95 & +0.05 & x 10. 00 & $289 \cdot 99$ & to. OI & 200.00 & 20.00 & 0.00 & 290.00 & IIO. OI & -o. or \\
\hline 25.00 & 204.96 & +o. 04 & II 5.00 & 295.00 & 0.00 & 205.00 & 25.00 & 0.00 & 295.00 & I 15.00 & o. 00 \\
\hline 30.00 & 209.95 & +o. 05 & 120.00 & 299.98 & +o. 02 & 210.00 & 30.00 & 0.00 & 300.00 & I2O. OI & -0.01 \\
\hline 35.00 & 214.96 & +o. 04 & 125.00 & 305.00 & 0.00 & 215.00 & 35.00 & 0.00 & 305.00 & I 25.00 & 0.00 \\
\hline 40.00 & 219.97 & +0.03 & I30. 00 & 310.00 & o. oo & 220.00 & 40.00 & 0.00 & 310.00 & I 30.00 & 0.00 \\
\hline 45.00 & 224.97 & +o. 03 & 135.00 & 314.99 & to. or & 225.00 & 45.00 & 0.00 & 315.00 & I 35.00 & 0.00 \\
\hline 50.00 & 229.97 & +0.03 & 140.00 & 319.99 & +o. or & 230.00 & 50.00 & o. oo & 320.00 & I 40.00 & 0.00 \\
\hline 55.00 & 234.97 & +0.03 & 145.00 & 325.00 & o. oo & 235.00 & 55. Or & -0.01 & 325.00 & I 44.99 & to. or \\
\hline 60.00 & 239.97 & +o. 03 & 150.00 & 330. 00 & 0.00 & 240.00 & 6o. or & -0.01 & 330.00 & r 49.98 & +0.02 \\
\hline 65.00 & $244.9^{8}$ & +o. 02 & 155.00 & $335 \cdot 00$ & 0.00 & 245.00 & 65.01 & -0.01 & 335.00 & I 54.98 & +0.02 \\
\hline 70.00 & 249.98 & +o. 02 & 160.00 & 340.00 & 0.00 & 250.00 & 70.02 & -0.02 & 340.00 & I 59.98 & +0.02 \\
\hline 75.00 & 254.99 & to. or & 165.00 & 345.00 & 0.00 & 255.00 & 75.02 & -0.02 & 345.00 & 164. 97 & +0.03 \\
\hline 80.00 & 259.99 & to.or & I 70.00 & 350.00 & 0.00 & 260.00 & $80.0 x$ & -0.01 & 350.00 & I69. 97 & +0.03 \\
\hline 85.00 & 264.98 & +0.02 & I 75.00 & 355.01 & -0.01 & 265.00 & 85.01 & -0.01 & 355.00 & I 74.96 & +o. 04 \\
\hline
\end{tabular}


If $P$ is the reading of either vernier, then the correction for eccentricity as determined from these readings is

$$
\Delta P=+0^{\circ} \text {.oro } \sin \left(P+229^{\circ} \cdot 3\right) \text {. }
$$

No correction for eccentricity has been applied to the measurements of position angles made with this micrometer, but Assistant Astronomer THEO I. KING, in his observations of the satellites of Jupiter, made a practice of reading both verniers and taking the mean, thus eliminating the effect of eccentricity.

The eyepieces. - There are two sets of eyepieces. One set consists of 9 negative eyepieces of the AIRY-Huygenian type and one HERSCHEL solar prism. The other set consists of 6 positive eyepieces of the KELLNER form.

The magnifying powers of these eyepieces as determined with the RAMSDEN dynameter and the fields of view are as follows:

Negative Eyepieces.

\begin{tabular}{|c|c|c|c|}
\hline $\begin{array}{l}\text { Desig- } \\
\text { nation. }\end{array}$ & $\begin{array}{l}\text { Magnifying } \\
\text { Power. }\end{array}$ & $\begin{array}{l}\text { Field of } \\
\text { View. }\end{array}$ & Maker. \\
\hline & Diameters. & ' & \\
\hline I & 37 & 66 & Kahler. \\
\hline II & 50 & $50^{\circ}$ & ، \\
\hline III & 85 & 3.3 & “" \\
\hline IV & II 8 & 26.5 & “" \\
\hline V & I96 & 15.6 & “" \\
\hline VI & $25^{8}$ & 9.2 & “ \\
\hline VII & 314 & 6.8 & “" \\
\hline VIII & $57 \mathrm{I}$ & $4 \cdot 5$ & “ \\
\hline IX & 790 & 3.0 & “ \\
\hline
\end{tabular}

Positive Eyepieces.

\begin{tabular}{|r|c|c|c|}
\hline $\begin{array}{c}\text { Desig- } \\
\text { nation. }\end{array}$ & $\begin{array}{c}\text { Magnifying } \\
\text { Power. }\end{array}$ & $\begin{array}{c}\text { Field of } \\
\text { View. }\end{array}$ & Maker. \\
\hline & Diameters. &, & \\
I & I I5 & 21.0 & Kahler. \\
II & 160 & 16.0 & “" \\
III & 235 & 12.4 & “ \\
IV & 335 & 8.0 & “ \\
V & 500 & 6.1 & “ \\
VI & 705 & 4.7 & “ \\
\hline
\end{tabular}

The chronograph. - A chronograph regulated by a HipP spring governor has been used continuously with this instrument in connection with a NEGus breakcircuit sidereal chronometer. The correction to the chronometer has been obtained by direct comparison with one of the standard clocks.

The instrumental constants. - The instrumental constants have been determined as follows:

\begin{tabular}{|c|c|c|c|c|c|c|c|c|}
\hline Date. & Obs'r. & Temp. & $\eta$ & $i_{1}-c$ & $\xi$ & $\begin{array}{c}c \\
\text { from } \\
\text { Stars. }\end{array}$ & $\varepsilon \cos \varphi$ & $\begin{array}{c}e \cos \varphi \\
\text { from } \\
\text { Stars. }\end{array}$ \\
\hline 1903 & & 。 & " & " & " & 'I & " & 11 \\
\hline Jan. I9 & K. & $2 \mathrm{IF}$ & +25 & -72 & +54 & $\ldots$ & $\therefore$ & $\ldots$ \\
\hline $\begin{array}{c}\text { Dec. } 6 \\
1904\end{array}$ & Hd. & 30 & +29 & -83 & +63 & +102 & +136 & +12 \\
\hline Jan. 27 & Hd. & $2 \mathrm{I}$ & +28 & -87 & +82 & +107 & +138 & +8 \\
\hline Apr. 4 & Hd. & 40 & +27 & -83 & +68 & $\ldots$ & $\ldots$ & . \\
\hline
\end{tabular}

No corrections have been applied to the observations for the effect of these constants. 


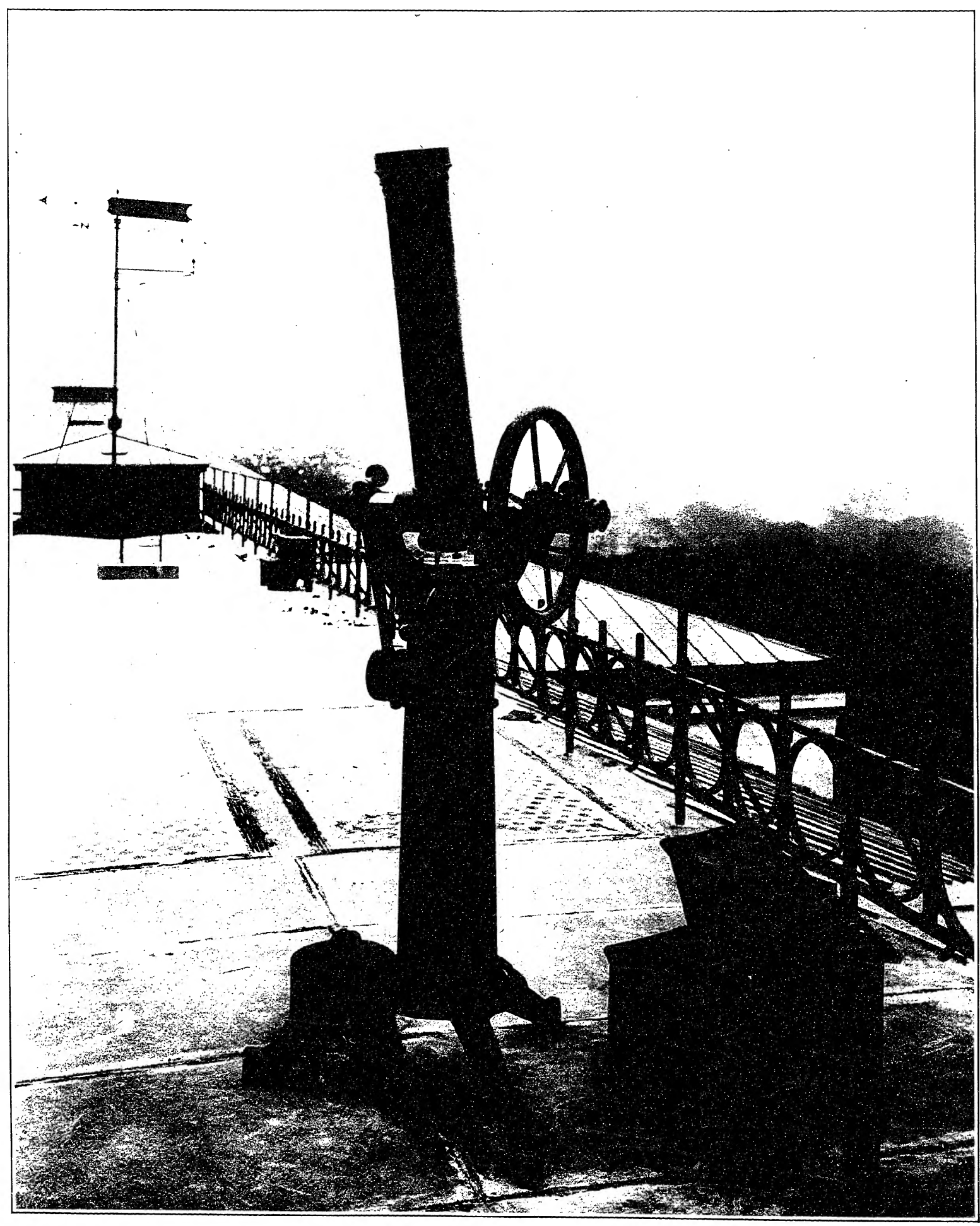

THE 5-INCH COMET SEEKER. 
There are two comet seekers. A description of one is contained in the Washington Astronomical Observations for I874, Volume XXI, Appendix I, page 20. It was made by UTZSCHNEIDER \& FRAUENHOFER, is equatorially mounted, and has an objective of 3.96 inches aperture and 32.4 inches focal length. It has five eyepieces, whose magnifying powers are approximately $\mathrm{r} 3.6, \mathrm{I} 9.4,40.6,40.8$, and 4 I.6. The last eyepiece is furnished with a ring micrometer.

The other comet seeker (see Plate X), made by John A. Brashear Co., of Allegheny, Pa., has an objective of 5 inches aperture and 40 inches focal length. It has an alt-azimuth mounting and the observer looks through the horizontal axis. It has five HUYGENIAN eyepieces whose magnifying powers are approximately $20,28,40$, 57 , and 80.

When these instruments are used they are placed on stands on the roof of the main building.

\section{OBSERVATIONS AND REDUCTIONS.}

The observations have been arranged in eight general classes as follows:

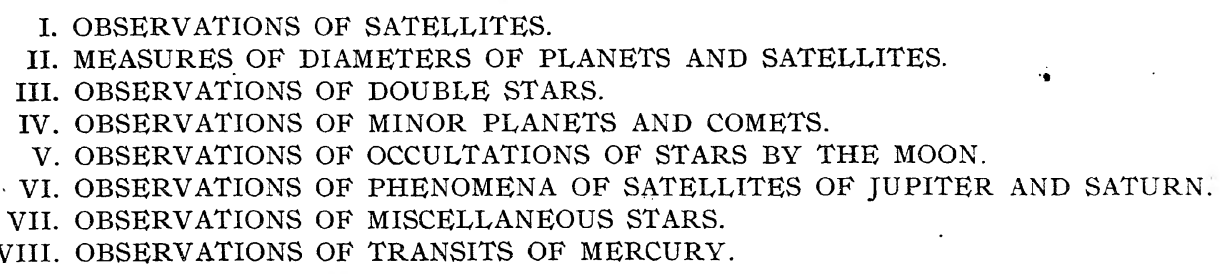

The observations of each object are printed in chronological order.

I. OBSERVATIONSS OF SATELLITES.

The satellites are arranged in order of their distances from the Sun, beginning with the satellites of Mars and ending with the satellite of Neptune.

The satellites of Mars. - The satellites of Mars have been observed at five oppositions, as is shown in the following table: The number of observations of each satellite at any opposition is given by the number opposite that satellite in the corresponding column.

\begin{tabular}{|c|c|c|c|c|c|}
\hline Opposition. & 1894 & 1896 & 1903 & 1905 & 1907 \\
\hline Phobos. & 35 & 7 & 2 & 0 & 14 \\
\hline Deimos.... & 31 & 24 & I & 2 & 12 \\
\hline
\end{tabular}

In 1907 the satellites were observed in rectangular coordinates by measuring from the limbs of the planet. At the other oppositions, the measures were made in position angle and distance from the estimated center of the illuminated disk of Mars. Corrections have been applied in all cases for differential refraction and for defective illumination. When the measures were made in position angle and distance

$28167^{\circ}-$ vol, $6-1 \mathrm{I}-\mathrm{IV}$ 
from the center of the illuminated disk of the planet, the corrections for defective illumination were computed from the formulæ

$$
\begin{aligned}
\Delta s & =-\frac{4 q}{3 \pi} \cos (p-Q), \\
s \sin \Delta p & =+\frac{4 q}{3 \pi} \sin (p-Q) .
\end{aligned}
$$

In these expressions $p$ and $s$ are the observed position angle and distance, respectively; $Q$ is the position angle and $q$ the amount of the greatest defect of illumination; $\pi$ is the constant 3.I4I6. The quantities $Q$ and $q$ were taken from MARTH's Ephemerides for Physical Observations of Mars, published in the Monthly Notices.

If we denote by $R_{1}$ and $R_{2}$ the measured distances of the satellite from the limbs of the planet in either rectangular coordinate $x$ or $y$, then the true distance of the satellite from the center of the planet corrected for defective illumination is

$$
x, y=\frac{R_{1}+R_{2}}{2} \pm \frac{a(f-0.500)}{f}
$$

where $a$ is the semi-diameter of the planet as above and $f$ is a tabular quantity corresponding to the coordinate $x, y$ and taken from TABLE XXV of the Reduction Tables for Transit Circle Observations, Publications of the United States Naval Observatory, Second Series, Volume IV, Appendix II. The proper sign for the correction

$$
\frac{a(f-0.500)}{f}
$$

is best determined in each case by reference to a rough diagram.

Beginning with 1903, corrections have also been applied for instrumental constants.

A discussion of the observations in $\mathrm{I} 894$ and I 896 by Prof. S. J. Brown, U. S. N., is published in the Astronomical Journal, No. 467.

The satellites of Jupiter. - The four bright satellites of Jupiter were observed in pairs, while Satellite VI was observed by determining the differences in right

\begin{tabular}{|c|c|c|c|c|}
\hline Satellites. & 1902 & $1903-04$ & I 9O4-O5 & I905-06 \\
\hline I-II & 5 & 39 & 37 & 19 \\
\hline I-III & 4 & 28 & 40 & 22 \\
\hline I-IV & 3 & $\mathrm{I}_{7}$ & o & o \\
\hline II-III & 4 & 26 & 36 & 24 \\
\hline II-IV & I & 23 & 0 & o \\
\hline III-IV & 3 & 17 & 37 & 20 \\
\hline VI & o & 0 & o & 8 \\
\hline
\end{tabular}
ascension and declination between it and some near reference star. The oppositions at which they were observed and the number of observations at each opposition are as follows: 
The measured position angles and distances of the pairs have been corrected for differential refraction.

The observed values of $\Delta \alpha$ and $\Delta \delta$ for Satellite VI have been corrected for differential refraction and for instrumental constants.

Satellite VII is not visible with the 26 -inch equatorial.

The satellites of Saturn.-The satellites of Saturn have always been observed in pairs with the single exception of Hyperion, which in I895 was measured directly with the planet. The following table shows the different combinations which were observed, as well as the oppositions and number of observations at each opposition:

\begin{tabular}{|c|c|c|c|c|c|c|c|c|c|c|c|c|}
\hline Satellites. & I 894 & I 895 & 1896 & 1898 & 1900 & 1901 & 1902 & 1903 & 1904 & 1905 & 1906 & 1907 \\
\hline Mimas-Enceladus. & o & o & o & 0 & o & o & o & 0 & 5 & 8 & 5 & o \\
\hline Mimas-'Tethys. & o & o & o & o & o & 23 & 37 & 3 & Io & 4 & 5 & ro \\
\hline Mimas-Dione........ & o & o & o & o & o & $\mathbf{I}$ & o & o & 3 & 5 & o & o \\
\hline Mimas-Rhea........ & o & $\mathrm{o}$ & o & o & o & o & o & o & 4 & 4 & 0 & 9 \\
\hline Enceladus-Tethys. . & o & o & o & o & 0 & 5.3 & 53 & 32 & 31 & 20 & 14 & 18 \\
\hline Tethys-Dione.... & o & 24 & 20 & o & 48 & 66 & 59 & 36 & 39 & 32 & I. 3 & 28 \\
\hline Tethys-Rhea. . . . . . & o & o & o & o & o & 0 & 24 & 52 & 43 & 35 & I6 & 26 \\
\hline Tethys-Titan ..... & o & 0 & o & o & o & o & 24 & 45 & 0 & $\mathrm{o}$ & o & o \\
\hline Tethys-Hyperion. . & o & o & o & o & o & o & o & 6 & o & o & o & o \\
\hline Tethys-Japetus... & o & o & o & o & o & o & 22 & 18 & 15 & o & o & o \\
\hline Dione-Rhea . . . . & o & o & $\mathrm{o}$ & o & $\mathrm{o}$ & o & 25 & 28 & 24 & 36 & 13 & 25 \\
\hline Rhea-Titan. . & $2 \mathbf{I}$ & o & o & o & 59 & 66 & $5^{8}$ & 47 & 37 & 39 & I4 & 24 \\
\hline Rhea-Japetus... & o & 23 & $\mathrm{o}$ & 35 & o & o & o & o & o & o & o & o \\
\hline Titan-Hyperion. ... & o & o & o & o & 2 & 32 & $3 I$ & 15 & I3 & 19 & 6 & 18 \\
\hline Hyperion...... & o & 5 & o & o & o & o & o & o & o & $\mathrm{o}$ & o & 0 \\
\hline Titan-Japetus.... & 26 & 25 & 24 & $\mathrm{o}$ & 0 & 55 & 49 & 43 & 32 & 40 & 20 & 32 \\
\hline
\end{tabular}

The pairs were usually observed in position angle and distance, the position angle being taken in every case about the inner satellite of the pair. When, however, the two satellites of any pair were widely separated, they were sometimes observed by determining the differences in right ascension and declination between them by the method of transits. In the latter case, the time of transit of the inner satellite of the pair was taken as the time of the observation, and the differences in $\alpha$ and $\delta$ were corrected for the motion of the planet in the interval between the transits.

In all cases the observations have been corrected for differential refraction and, beginning with the year 1903 , corrections have been applied for instrumental constants.

Phœbe, the ninth satellite of Saturn, has been searched for on several occasions but unsuccessfully.

The observations of Titan-Japetus in I894, I895, and r896 have been discussed by Prof. S. J. Brown, U. S. N., in the Astronomical Journal, No. 443.

The satellites of Uranus.-The inner satellites of Uranus, Ariel, and Umbriel are extremely difficult objects to observe when the planet is at such low altitudes as it 
has been during the time covered by these observations. They have been seen only on rare occasions and no attempt has been made to secure a series of observations of them except in I9OI.

The outer satellites are fairly easy objects to observe with the 26 -inch objective. They have been observed directly with Uranus and also with each other, as shown by the following table:

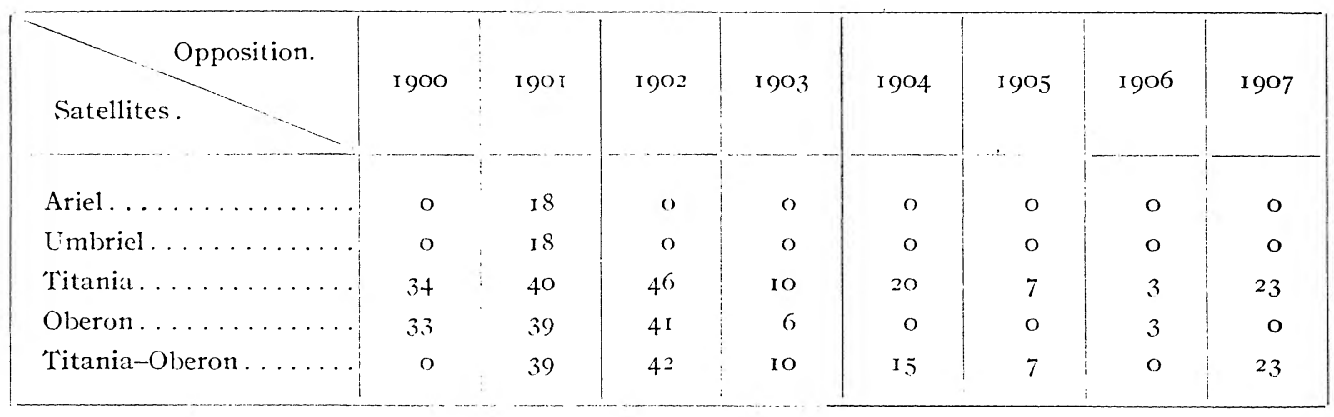

All measures have been made in position angle and distance, and corrections have been applied throughout for differential refraction and, from I903 to I907 inclusive, for instrumental constants.

The satellite of Neptune. - The following table gives the oppositions at which the satellite of Neptune has been observed and the number of observations at each opposition:

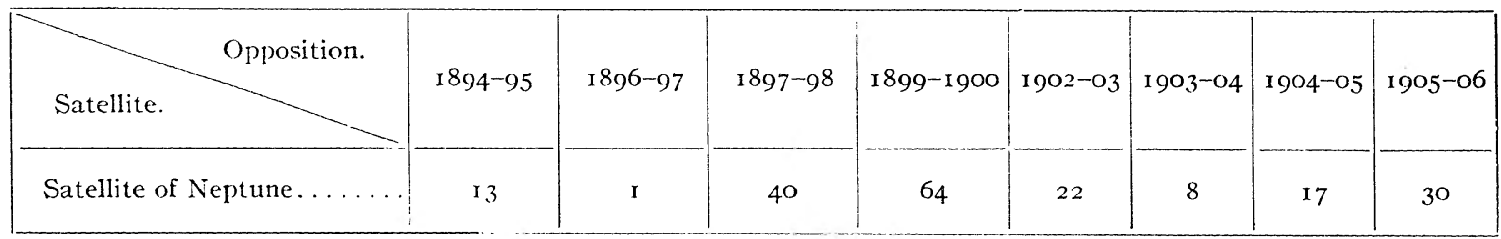

The measures have been corrected for differential refraction, and from I903 to 1906 inclusive, for instrumental constants.

A discussion of the observations of $1897-98$ by Prof. S. J. Brown, U. S. N., is published in the Astronomical Journal, No. 473 .

The observations at the opposition r899-I900 have been discussed by Prof. T. J. J. SEE, U. S. N., in the Astronomische Nachrichten, Nr. 3663.

\section{MEASURES OF DIAMETERS OF PLANETS AND SATELLITES.}

Under this head are included measures of the diameters of the planets Mercury, Venus, Mars, Jupiter, Saturn, Uranus, and Neptune; the North Polar Cap of Mars, the four bright satellites of Jupiter, and two of the satellites of Saturn, Titan and Japetus. Measures of the ring system of Saturn are also included. The following table gives the years in which they were observed and the number of observations in each year: 
INTRODUCTION.

A XXXviI

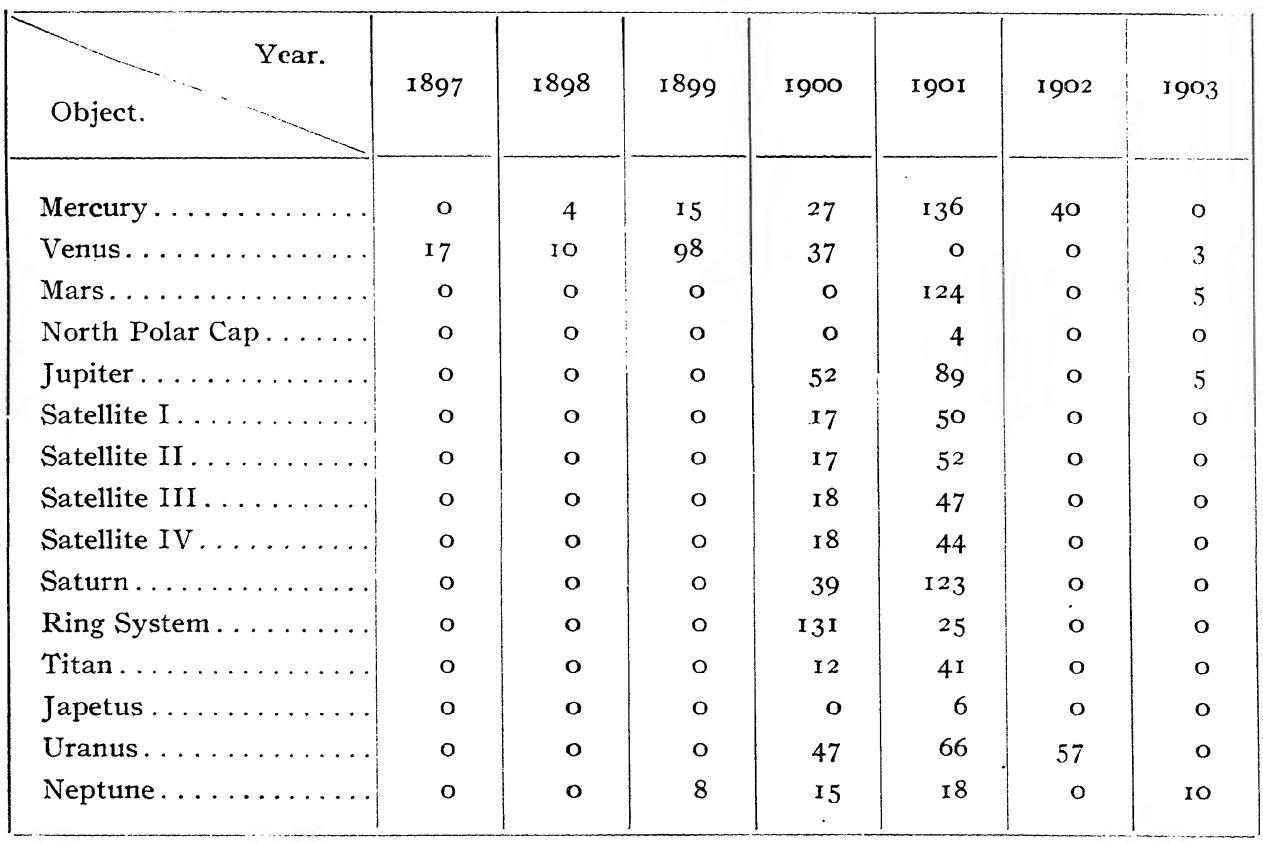

Mercury. - The diameters of Mercury have all been measured along the phase axis and therefore no correction has been necessary for phase. The correction for differential refraction is negligible in every case. A discussion of the measures made in I900 and I90r by Professor SEE is published in the Astronomische Nachrichten, Nr. 3737 .

Venus.-The diameters of Venus have been measured along the phase axis and also in position angles $0^{\circ}-180^{\circ}$ and $90^{\circ}-270^{\circ}$. The results are printed separately, and columns of corrections for differential refraction and for phase are given. The latter correction was computed by means of auxiliary quantities taken from the table Illuminated Disk of Venus in the American Ephemeris. A discussion of the measures in I900 by Professor SEE is published in the Astronomische Nachrichten, Nr. 3676 .

Mars. - The diameters of Mars have been measured along the phase axis, perpendicular to the phase axis, and in position angles $0^{\circ}-180^{\circ}$ and $90^{\circ}-270^{\circ}$. The results are printed separately. A column is given for the correction for differential refraction and one for phase whenever appreciable. The latter correction for the diameters measured in position angles $0^{\circ}-180^{\circ}$ and $90^{\circ}-270^{\circ}$ was computed from auxiliary quantities taken from the table Illuminated Disk of Mars in the American Ephemeris.

The diameters measured perpendicular to the phase axis in I90I were corrected for phase from Ephemeris for Physical Observations of Mars by A. C. D. CROMmELIN in Monthly Notices, Volume 6o, page 232 et seq.

A discussion of the measures in I9OI by Professor SEE is published in the Astronomische Nachrichten, Nr. 3750.

Jupiter and satellites.-The equatorial and polar diameters of Jupiter were measured and the results are printed separately. Columns are given of corrections for differential refraction and for phase. The corrections for phase were taken from 
Ephemerides for Physical Observations of Jupiter by A. C. D. Crommenin in Monthly Notices, Volume 6o, page 60, and Volume 6r, page 94 et seq. The measured diameters of the satellites of course require no corrections. A discussion of the measures in I900 by Professor SEE is published in the Astronomische Nachrichten, Nr. 3670. A discussion of the measures in I90I by Professor SEE is found in the Astronomische Nachrichten, Nr. 3757 and Nr. 3764.

Saturn and the rings.-The equatorial diameter of Saturn only was measured. A column of corrections for differential refraction is given and one for phase. The latter correction was computed by the formula

$$
\text { Phase }=d \cdot \tan ^{2} \frac{\pi}{2}
$$

when $d$ is the measured diameter and

$$
\sin \pi=\frac{R \sin (l-L)}{4} .
$$

In the latter expression $R$ is the distance of the Earth from the Sun, $\Delta$ is the distance of Saturn from the Earth, and $l-L$ is the difference in the heliocentric longitude of the Earth and Saturn.

In the measures of the ring system a column of corrections for differential refraction is given whenever it is appreciable.

No corrections of course are necessary to the measures of the diameters of Titan and Japetus.

Discussions of the measures in the different years by Professor SEE are published in the Astronomische Nachrichten, Nr. 3686, Nr. 3764, and Nr. 3768.

Uranus and Neptune.-The diameters of Uranus and Neptune were measured in position angles $0^{\circ}-180^{\circ}$ and $90^{\circ}-270^{\circ}$. Corrections for differential refraction and for phase are negligible for both planets.

Discussions of the diameters of these planets by Professor SEE are published in the Astronomische Nachrichten, Nr. 3665, and Nr. 3768.

The measured diameters have all been reduced to the values corresponding to the distance unity.

In the years I900, I901, and I902 color cells were used on the 26-inch equatorial by Professor SEE in his measures of diameters. The object of these cells was to absorb the outstanding blue light of the secondary spectrum. They were placed in front of the eyepiece and held in place by an adapter as described in the Astronomische Nachrichten, Nr. 3636 . These cells were filled with different fluids and are designated by the numbers $\mathrm{I}, 2,3,4$, and 5 .

The solution in cell I was bichromate of potash; in cell 2 was chromate of potash until July I5, I900, after which date picric acid and chloride of copper in water; in cells 3 and 4 was chloride of copper and picric acid in alcohol. The solution used in cell 5 is uncertain.

III. OBSERVATIONS OF DOUBLE STARS.

The observations of double stars consist chiefly of those stars discovered by the STRUVES and by Burnham. Numbers 4I, II6, I38, I39, I42, I83, 2 I5, 325, 326, $332,396,423,45^{6}, 523$, and 565 in the following table are doubles which were discovered by Professor SKINNER in the course of his observations of stars in the Washing- 
ton A. G. Zones with the 9-inch transit circle. Numbers 2 I 5 and 325 are not contained in Burnham's General Catalogue of Double Stars. Numbers 456 and 565 were independently discovered by Prof. W. J. Hussey and announced by him before the announcement of Professor SkINNER's discovery.

No attempt has been made to discover new double stars. However, in the observations of asteroids, one comparison star, B. D. $+4^{\circ} 405$, was found by Mr. HAmmond to have a faint companion and it is thought to be a new double.

Corrections for differential refraction have been applied whenever appreciable. The means of the measured position angles and distances have been taken for each year.

TABLE XII shows the double stars observed, the years in which they were observed, and the number of observations in each year.

TABLE XII.

\begin{tabular}{|c|c|c|c|c|c|}
\hline No. & Name. & $\begin{array}{l}\text { R. A. } \\
\text { rgoo. }\end{array}$ & Decl. I900. & Year. & $\begin{array}{l}\text { No. of } \\
\text { Obs. }\end{array}$ \\
\hline $\mathbf{I}$ & $\beta$ ror $4 \ldots \ldots \ldots \ldots \ldots$ & $\begin{array}{rr}\mathrm{h} & \mathrm{m} \\
\mathrm{o} & 2\end{array}$ & $\begin{array}{r}0 \\
+31 \\
+7\end{array}$ & I 899 & I \\
\hline 2 & $\Sigma 3063 \ldots \ldots \ldots$ & 02 & -56 & $\begin{array}{l}1901 \\
1903 \\
1904\end{array}$ & $\begin{array}{l}4 \\
1 \\
3\end{array}$ \\
\hline 3 & $\Sigma 3065 \ldots \ldots \ldots \ldots \ldots \ldots$ & o 3 & -1447 & 1900 & I \\
\hline 4 & 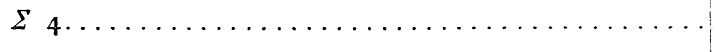 & o 5 & +754 & I9OI & 3 \\
\hline 5 & $\beta 255 \ldots \ldots \ldots \ldots \ldots$ & ० 7 & +2752 & rgoI & 2 \\
\hline 6 & $\beta 998 \ldots \ldots \ldots \ldots \ldots \ldots$ & $\circ 9$ & +62 & 1901 & 3 \\
\hline 7 & $\beta 486 \ldots \ldots \ldots \ldots$ & 0 9 & -820 & 190I & 2 \\
\hline 8 & 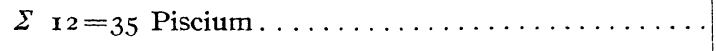 & o ro & +816 & 1901 & $\mathbf{I}$ \\
\hline 9 & Hu $3 \ldots \ldots \ldots \ldots \ldots \ldots \ldots \ldots \ldots \ldots \ldots$ & O I 2 & - Io 54 & 1903 & $\mathbf{r}$ \\
\hline Io & 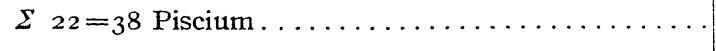 & O 12 & +819 & 1901 & 3 \\
\hline II & $\beta 393 \ldots \ldots \ldots \ldots \ldots \ldots \ldots \ldots \ldots \ldots \ldots \ldots \ldots$ & O I 3 & -2 I 42 & I 899 & $\mathbf{I}$ \\
\hline 12 & $\beta 256 \ldots \ldots \ldots \ldots \ldots \ldots \ldots$ & O 15 & -1423 & $\begin{array}{l}1900 \\
1904\end{array}$ & $\begin{array}{l}\mathbf{I} \\
\mathbf{I}\end{array}$ \\
\hline I3 & $\beta$ ror5 $\ldots \ldots \ldots$ & O 15 & + I I 45 & $\begin{array}{l}\text { ז } 897 \\
\text { 1 } 898 \\
\text { 1 } 899\end{array}$ & $\begin{array}{l}\text { I } \\
\text { I } \\
2\end{array}$ \\
\hline 14 & 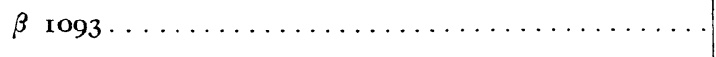 & o 16 & tro 25 & 1899 & $\mathbf{I}$ \\
\hline .15 & $\beta 777 \ldots \ldots \ldots \ldots \ldots \ldots \ldots \ldots \ldots \ldots \ldots$ & о 16 & - o 49 & I9OI & I \\
\hline I6 & $\beta 488 \ldots \ldots \ldots \ldots \ldots \ldots$ & 019 & -42 & $\begin{array}{l}1901 \\
1904\end{array}$ & $\begin{array}{l}\text { I } \\
\text { I }\end{array}$ \\
\hline 17 & 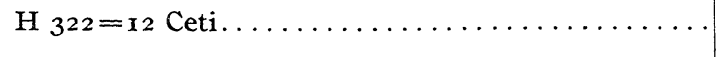 & 025 & -431 & I9OI & I \\
\hline 18 & 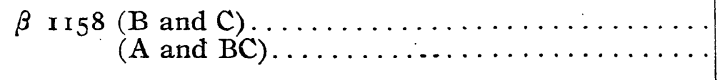 & o 26 & -1038 & $\begin{array}{l}\text { I9OI } \\
\text { I9OI }\end{array}$ & $\begin{array}{l}\text { I } \\
\text { I }\end{array}$ \\
\hline 19 & $\begin{array}{r}\text { Ho } 21_{2}=1_{3} \text { Ceti }(A \text { and } B) \ldots \ldots \ldots \ldots \ldots \ldots \\
\qquad(A B \text { and } C) \ldots \ldots \ldots \ldots \ldots\end{array}$ & o 30 & -49 & $\begin{array}{l}\text { I } 899 \\
\text { 1900 } \\
\text { r } 899\end{array}$ & $\begin{array}{l}\text { I } \\
\text { I } \\
\text { I }\end{array}$ \\
\hline 20 & 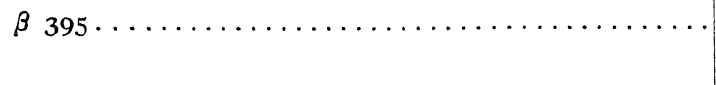 & o 32 & -2519 & $\begin{array}{l}1899 \\
1900\end{array}$ & $\begin{array}{l}2 \\
I\end{array}$ \\
\hline
\end{tabular}


TABLE XII-Continued.

\begin{tabular}{|c|c|c|c|c|c|}
\hline No. & Name. & $\begin{array}{l}\text { R. A. } \\
\text { I9Oo. }\end{array}$ & Decl. 1900. & Year. & $\begin{array}{l}\text { No. of } \\
\text { Obs. }\end{array}$ \\
\hline $2 \mathrm{I}$ & $\Sigma \quad 49 \ldots \ldots \ldots \ldots \ldots \ldots$ & $\begin{array}{lr}\text { h } & \text { m } \\
0 & 36\end{array}$ & $\begin{array}{r}\circ, \\
-747\end{array}$ & $\begin{array}{l}1901 \\
1904\end{array}$ & $\begin{array}{l}\mathbf{I} \\
2\end{array}$ \\
\hline 22 & 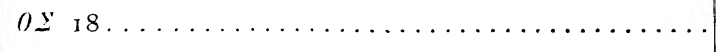 & o 37 & +337 & 1901 & I \\
\hline 23 & 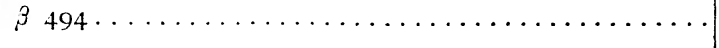 & O $4^{2}$ & $-\mathrm{I} 48$ & 1903 & 2 \\
\hline 24 & 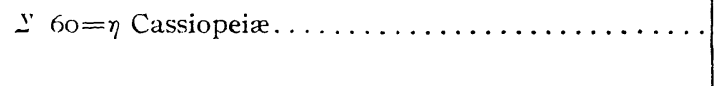 & o 43 & $+57 \quad 17$ & $\begin{array}{l}1899 \\
1902\end{array}$ & $\mathbf{I}$ \\
\hline 2.5 & 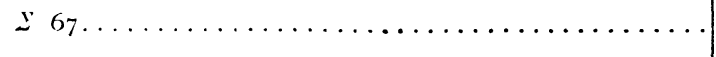 & o 47 & +103 & 1906 & I \\
\hline 26 & O. Stone $3 \ldots \ldots \ldots \ldots \ldots$ & o 47 & -239 & $\begin{array}{l}1903 \\
1904\end{array}$ & $\begin{array}{l}2 \\
2\end{array}$ \\
\hline 27 & O. Stone $4 \ldots \ldots \ldots \ldots \ldots \ldots \ldots$ & o $4^{8}$ & -2519 & 1904 & 2 \\
\hline 28 & $\Sigma 74 \ldots \ldots \ldots \ldots$ & o $5^{\circ}$ & +853 & 1902 & I \\
\hline 29 & $\beta 302 \ldots \ldots \ldots \ldots$ & o 53 & $+205^{2}$ & 1898 & 2 \\
\hline 30 & $S 390 \ldots \ldots \ldots$ & о 53 & -16 I3 & $\begin{array}{l}1902 \\
1904\end{array}$ & $\begin{array}{l}3 \\
3\end{array}$ \\
\hline $3 \mathrm{I}$ & $\beta 234 \ldots \ldots \ldots \ldots \ldots \ldots \ldots$ & o 56 & -1737 & 1904 & 2 \\
\hline 32 & $\mathrm{Hn} 62 \ldots \ldots \ldots \ldots \ldots$ & о 57 & -924 & 1903 & 2 \\
\hline 33 & $\Sigma 87 \ldots \ldots \ldots \ldots \ldots \ldots \ldots$ & I $O$ & +1452 & 1902 & I \\
\hline 34 & 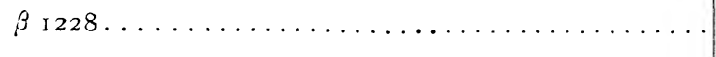 & I I & +1247 & 1899 & 2 \\
\hline 35 & $\beta_{5}$ Or $\ldots \ldots \ldots \ldots \ldots \ldots \ldots \ldots \ldots \ldots \ldots \ldots$ & I 2 & -5 I I & I 901 & I \\
\hline 36 & $\Sigma q_{91} \ldots \ldots \ldots \ldots \ldots \ldots \ldots$ & I 2 & -216 & $\begin{array}{l}1901 \\
1902 \\
1903 \\
1904\end{array}$ & $\begin{array}{l}2 \\
3 \\
\mathrm{I} \\
\mathrm{I}\end{array}$ \\
\hline 37 & $\beta_{502} \ldots \ldots \ldots \ldots \ldots \ldots$ & I 3 & +1515 & 1901 & I \\
\hline 38 & $O \Sigma_{515}=\phi$ Andromedæ...... & I 4 & +4642 & I 899 & I \\
\hline 39 & $\beta_{303}=201$ Piscium $\ldots \ldots \ldots$ & I 4 & +2316 & I9OI & I \\
\hline 40 & $\beta 2 \ldots \ldots \ldots \ldots \ldots \ldots$ & I 5 & +2920 & 1901 & $\mathbf{I}$ \\
\hline $4 \mathrm{I}$ & Skinner $\mathbf{1} \ldots \ldots \ldots \ldots \ldots$ & I 7 & -14 10 & 1900 & I \\
\hline 42 & $\beta 503 \ldots \ldots \ldots \ldots \ldots \ldots \ldots$ & I 12 & tro 4 & $\begin{array}{l}1899 \\
1901\end{array}$ & $\begin{array}{l}2 \\
1\end{array}$ \\
\hline 43 & $\beta_{5} \mathrm{O} \ldots \ldots \ldots \ldots \ldots \cdots \cdots$ & I 12 & $+x 19$ & $\begin{array}{l}1897 \\
1899 \\
1901 \\
1902\end{array}$ & $\begin{array}{l}3 \\
3 \\
\mathrm{I} \\
\mathrm{I}\end{array}$ \\
\hline 44 & $\Sigma_{\text {II } 3=42}$ Ceti. $\ldots \ldots \ldots \ldots \ldots \ldots \ldots$ & I 15 & -12 & $\begin{array}{l}1901 \\
1902 \\
1903\end{array}$ & $\begin{array}{l}\text { I } \\
\text { I } \\
2\end{array}$ \\
\hline 45 & 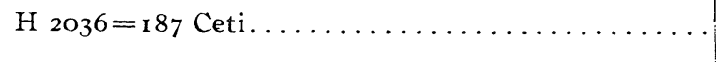 & I 15 & -1620 & 1902 & $\mathbf{I}$ \\
\hline 46 & 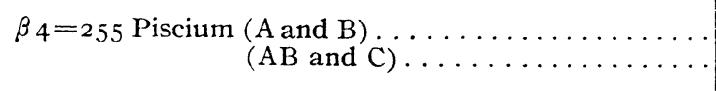 & I 16 & $+11 \quad I$ & $\begin{array}{l}1899 \\
1899\end{array}$ & $\begin{array}{l}2 \\
1\end{array}$ \\
\hline 47 & 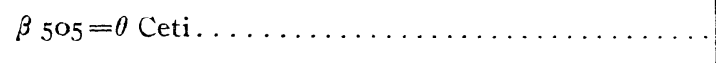 & I 19 & $-84^{2}$ & 1899 & $\mathbf{I}$ \\
\hline $4^{8}$ & 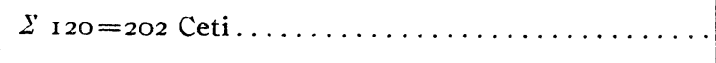 & I 20 & -628 & 1901 & $\mathbf{I}$ \\
\hline 49 & $\Sigma$ I22, $\ldots \ldots \ldots \ldots$ & I 22 & $+3 \mathrm{I}$ & 1901 & I \\
\hline
\end{tabular}


TABLE XII-Continued.

\begin{tabular}{|c|c|c|c|c|c|}
\hline No. & Name. & $\begin{array}{l}\text { R. A. } \\
\text { Igoo. }\end{array}$ & Decl. rgoo. & Year. & $\begin{array}{l}\text { No. of } \\
\text { Obs. }\end{array}$ \\
\hline 50 & $\beta_{1164=95}$ Piscium $\ldots \ldots \ldots \ldots \ldots \ldots \ldots \ldots \ldots$ & $\begin{array}{cc}\text { h } & \mathrm{m} \\
\mathrm{I} & 22\end{array}$ & $\begin{array}{r}\circ \\
+450\end{array}$ & 1901 & I \\
\hline $5 \mathrm{I}$ & 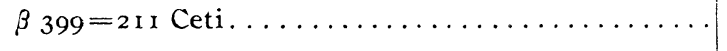 & 1 23 & - II 25 & 1903 & I \\
\hline $5^{2}$ & 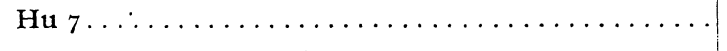 & I 23 & -948 & 1903 & I \\
\hline 53 & $\beta 869 \ldots \ldots \ldots \ldots \ldots \ldots \ldots \ldots$ & I $3 \mathrm{I}$ & +348 & 1901 & I \\
\hline 54 & 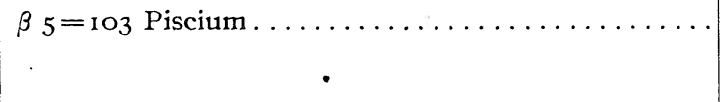 & I 34 & +167 & $\begin{array}{l}1897 \\
1898 \\
1899\end{array}$ & $\begin{array}{l}\mathrm{I} \\
2 \\
2\end{array}$ \\
\hline 55 & 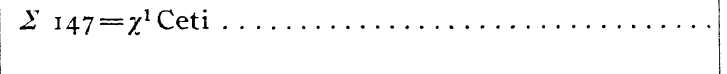 & I 37 & -1149 & $\begin{array}{l}1903 \\
1904\end{array}$ & $\begin{array}{l}1 \\
2\end{array}$ \\
\hline 56 & 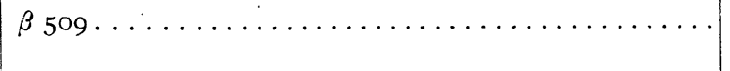 & I 38 & +94 & $\begin{array}{l}1897 \\
1899\end{array}$ & $\begin{array}{l}\text { I } \\
2\end{array}$ \\
\hline 57 & 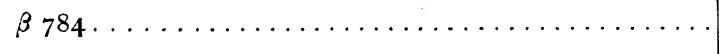 & I $4 \mathrm{I}$ & +2224 & I 899 & I \\
\hline $5^{8}$ & 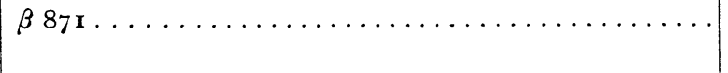 & I 43 & -127 & $\begin{array}{l}1903 \\
1904\end{array}$ & I \\
\hline 59 & $\beta 260 \ldots \ldots \ldots \ldots \ldots \ldots \ldots \ldots$ & I 48 & +1456 & $\begin{array}{l}1897 \\
1898 \\
1900\end{array}$ & $\begin{array}{l}I \\
1 \\
2\end{array}$ \\
\hline 60 & 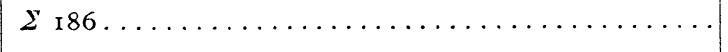 & I 5 I & +121 & I 899 & 2 \\
\hline 61 & 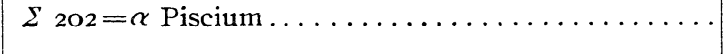 & I 57 & +217 & 1902 & I \\
\hline 62 & 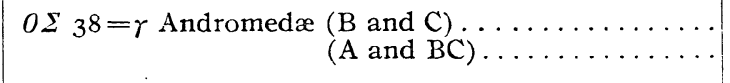 & I 58 & +4151 & $\begin{array}{l}1899 \\
1899\end{array}$ & I \\
\hline 63 & 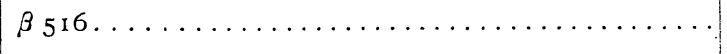 & 20 & -127 & 1901 & I \\
\hline $64^{\prime}$ & $\Sigma 218 \ldots \ldots \ldots \ldots$ & $\begin{array}{rr}24 \\
.\end{array}$ & $-\circ 55$ & $\begin{array}{l}1901 \\
1903 \\
1905\end{array}$ & $\begin{array}{l}\text { I } \\
2 \\
\text { I }\end{array}$ \\
\hline 65 & Hastings. . . . . . . . . . . & 2 I I & -1842 & 1903 & I \\
\hline 66 & 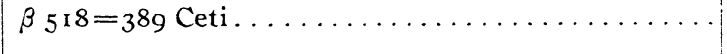 & 224 & +97 & I901 & I \\
\hline 67 & Hammond $\left[\mathrm{BD}+4^{\circ} 4 \mathrm{O} 5\right] \ldots \ldots$ & 224 & +426 & $\begin{array}{l}1907 \\
1908\end{array}$ & $\begin{array}{l}\text { I } \\
\text { I }\end{array}$ \\
\hline 68 & $\dot{\beta}_{5} 19 \ldots \ldots \ldots \ldots \ldots \ldots \ldots \ldots \ldots \ldots$ & 225 & -243 & $\begin{array}{l}\text { I900 } \\
\text { 1901 }\end{array}$ & I \\
\hline 69 & Howe $6 \ldots \ldots \ldots \ldots \ldots \ldots$ & 227 & -80 & 1903 & $\mathbf{I}$ \\
\hline 70 & $\Sigma 280 \ldots \ldots \ldots$ & 229 & -64 & $\begin{array}{l}1903 \\
1905\end{array}$ & $\begin{array}{l}4 \\
\mathbf{I}\end{array}$ \\
\hline $7 \mathrm{I}$ & $\beta 520 \ldots \ldots \ldots \ldots \ldots \ldots \ldots$ & 232 & -40 & $\begin{array}{l}1900 \\
1901\end{array}$ & $\mathbf{I}$ \\
\hline 72 & 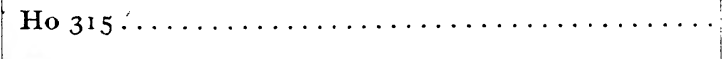 & 234 & -21 & 1903 & 3 \\
\hline 73 & $\Sigma_{295}=84$ Ceti. $\ldots \ldots \ldots \ldots \ldots \ldots \ldots \ldots \ldots \ldots$ & 236 & $-1,7$ & $\begin{array}{l}1902 \\
\text { 1903 }\end{array}$ & $\begin{array}{l}2 \\
3\end{array}$ \\
\hline 74 & 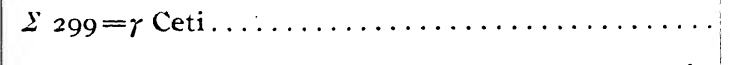 & 238 & +249 & 1902 & $\mathbf{I}$ \\
\hline $\begin{array}{l}75 \\
:\end{array}$ & 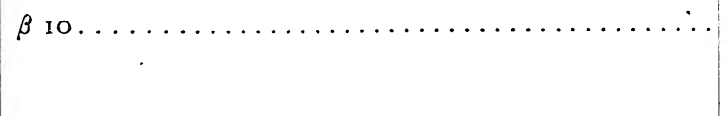 & 245 & -524 & $\begin{array}{l}1898 \\
1900 \\
1903\end{array}$ & $\begin{array}{l}1 \\
2 \\
3\end{array}$ \\
\hline 76 & 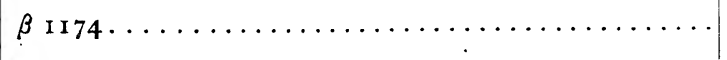 & 259 & -1122 & 1900 & 2 \\
\hline
\end{tabular}


TABLE XII-Continued.

\begin{tabular}{|c|c|c|c|c|c|}
\hline No. & Name. & $\begin{array}{l}\text { R. A. } \\
\text { I9oo. }\end{array}$ & Decl. 1900. & Year. & $\begin{array}{l}\text { No. of } \\
\text { Obs. }\end{array}$ \\
\hline 77 & 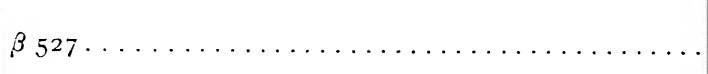 & $\begin{array}{cc}\mathrm{h} & \mathrm{m} \\
3 & \mathrm{I}\end{array}$ & $\begin{array}{cc}\circ \\
-1349\end{array}$ & 1900 & I \\
\hline 78 & A. Clark $2=95$ Ceti. . . . . . . & 313 & - I 18 & I 899 & 2 \\
\hline 79 & $\beta \mp 2 \ldots \ldots \ldots \ldots \ldots$ & 320 & $-\mathrm{I} 42 \mathrm{I}$ & 1903 & I \\
\hline 80 & $\beta 532 \ldots \ldots \ldots \ldots \ldots \ldots$ & 328 & -1023 & 1900 & I \\
\hline $8 \mathrm{I}$ & $\beta$ 1003 $\ldots \ldots \ldots \ldots \ldots \ldots$ & $34 \mathrm{I}$ & -28 II & $\begin{array}{l}1899 \\
1900\end{array}$ & $\begin{array}{l}\text { I } \\
\text { I }\end{array}$ \\
\hline 82 & $o \Sigma 65 \ldots \ldots \ldots \ldots \ldots \ldots \ldots$ & 344 & +2517 & I 898 & 2 \\
\hline 83 & $\beta_{54 \mathrm{I}} \ldots \ldots \ldots \ldots \ldots \ldots$ & 350 & - I 34 & $\begin{array}{l}\mathbf{1} 899 \\
1900\end{array}$ & $\begin{array}{l}\mathrm{I} \\
\mathrm{I}\end{array}$ \\
\hline 84 & See. . . . . . . . . . . . & 352 & - I $5^{2}$ & 1900 & $\mathbf{I}$ \\
\hline 85 & $\beta 543 \ldots \ldots \ldots \ldots \ldots$ & 352 & - I 27 & $\begin{array}{l}\text { I } 899 \\
\text { I } 900\end{array}$ & $\begin{array}{l}\text { I } \\
\text { I }\end{array}$ \\
\hline 86 & $\beta 1042\left(\begin{array}{l}(\mathrm{A} \text { and } \mathrm{B}) \\
(\mathrm{B} \text { and } \mathrm{C}) \ldots \ldots \ldots \ldots \ldots \ldots \ldots \ldots \ldots \ldots \ldots\end{array}\right.$ & 354 & -256 & $\begin{array}{l}\text { г } 899 \\
\text { I } 899\end{array}$ & $\begin{array}{l}\mathbf{I} \\
\mathbf{I}\end{array}$ \\
\hline 87 & $\beta 1005 \ldots \ldots \ldots \ldots$ & $4 \mathrm{I}$ & +2840 & r 899 & $\mathbf{I}$ \\
\hline 88 & $O \Sigma 531 \ldots \ldots \ldots \ldots$ & $4 \mathrm{I}$ & +3749 & I 898 & $\mathbf{r}$ \\
\hline 89 & $\mathrm{Hu} 8 \mathrm{r} 7 \ldots \ldots \ldots \ldots \ldots$ & 412 & +3223 & $\begin{array}{l}1907 \\
1908\end{array}$ & $\begin{array}{l}\text { I } \\
\text { I }\end{array}$ \\
\hline 90 & $\Sigma 536 \ldots \ldots \ldots \ldots \ldots \ldots \ldots$ & $4 \mathrm{I} 7$ & -455 & I903 & 2 \\
\hline 91 & $\beta 744=299$ Eridani $\ldots \ldots \ldots$ & $4 \mathrm{I} 7$ & $-255^{8}$ & I900 & I \\
\hline 92 & $\Sigma 535=230$ Tauri $\ldots \ldots \ldots \ldots$ & 4 I 8 & $+\mathrm{Ir} 9$ & 1902 & $\mathbf{r}$ \\
\hline 93 & $\beta$ 1235 $\ldots \ldots \ldots \ldots$ & 419 & $+223 r$ & г 899 & $\mathbf{I}$ \\
\hline 94 & $\beta$ I $86=248$ Tauri $\ldots \ldots \ldots$ & 422 & tro 59 & I 900 & $\mathbf{I}$ \\
\hline 95 & $\Sigma_{554}=80$ Tauri $\ldots \ldots \ldots$ & 424 & +1525 & I900 & $\mathrm{r}$ \\
\hline 96 & $\Sigma 590=55$ Eridani........ & 439 & -859 & 1903 & $\mathbf{I}$ \\
\hline 97 & $(\mathrm{AB}$ and $\mathrm{C}) \ldots \ldots$ & 446 & tro 54 & $\begin{array}{l}1899 \\
1901 \\
1902 \\
\\
1899 \\
\text { r } 902\end{array}$ & $\begin{array}{l}3 \\
1 \\
1 \\
2 \\
1\end{array}$ \\
\hline 98 & $\beta 55^{2}=\mathrm{I}$ I Orionis $\ldots \ldots \ldots \ldots$ & 446 & +1329 & $\begin{array}{l}\mathbf{1} 899 \\
\mathbf{1 9 0 2}\end{array}$ & $\begin{array}{l}3 \\
\mathbf{1}\end{array}$ \\
\hline 99 & $\beta$ I237 $\ldots \ldots \ldots \ldots \ldots$ & 448 & +2323 & I90 I & $\mathbf{I}$ \\
\hline 100 & $o \Sigma 90 \ldots \ldots \ldots \ldots \ldots \ldots \ldots$ & 450 & +826 & $\mathbf{1} 898$ & I \\
\hline IOI & $\beta 314=3$ Leporis $(A$ and $B) \ldots \ldots \ldots$ & 455 & -1632 & $\begin{array}{l}\text { I } 898 \\
\text { I } 899\end{array}$ & $\begin{array}{l}\text { I } \\
\text { I }\end{array}$ \\
\hline 102 & $o \Sigma 93 \ldots \ldots \ldots \ldots \ldots \ldots \ldots \ldots \ldots \ldots \ldots \ldots \ldots \ldots$ & 455 & +457 & I 898 & $\mathrm{I}$ \\
\hline 103 & 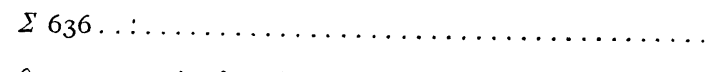 & 458 & -848 & 1903 & I \\
\hline 104 & $\beta$ I047 $=47$ Aurigæ $(A$ and $B) \ldots \ldots \ldots \ldots$ & 53 & +2754 & I 899 & $\mathbf{x}$ \\
\hline 105 & 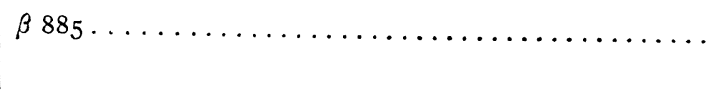 & 56 & - I 53 & $\begin{array}{l}\text { I } 898 \\
\text { I } 899\end{array}$ & $\begin{array}{l}\text { I } \\
2\end{array}$ \\
\hline
\end{tabular}


INTRODUCTION.

A XLIII

TABLE XII-Continued.

\begin{tabular}{|c|c|c|c|c|c|}
\hline No. & Name. & $\begin{array}{l}\text { R. A. } \\
1900 .\end{array}$ & Decl. 1900. & Year. & $\begin{array}{l}\text { No. of } \\
\text { Obs. }\end{array}$ \\
\hline 106 & 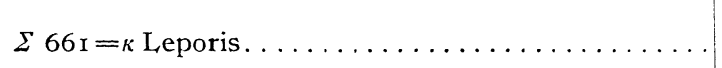 & $\begin{array}{cc}\mathrm{h} & \mathrm{m} \\
5 & 9\end{array}$ & $\begin{array}{rr}\circ \\
-13 & 4\end{array}$ & I903 & 2 \\
\hline I07 & $\beta 3$ I $8 \ldots \ldots \ldots \ldots$ & $5 \mathrm{II}$ & -336 & $\begin{array}{l}1898 \\
1899\end{array}$ & $\begin{array}{l}\text { I } \\
\text { I }\end{array}$ \\
\hline 108 & $\Sigma 728=32$ Orionis . . & 525 & +552 & $\begin{array}{l}1899 \\
1900\end{array}$ & I \\
\hline 109 & $\Sigma 729=33$ Orionis $\ldots \ldots \ldots \ldots \ldots \ldots \ldots$ & 526 & +313 & 1903 & I \\
\hline I IO & $\Sigma 738=\lambda$ Orionis & 530 & $+95^{1}$ & 1903 & I \\
\hline I I I & $\Sigma 774=\zeta$ Orionis $(\mathrm{A}$ and $\mathrm{B})$ & 536 & -20 & 1903 & I \\
\hline II 2 & $O \Sigma \mathrm{I}_{15} \ldots \ldots \ldots \ldots$ & 539 & $+I_{5} \quad \mathrm{I}$ & 1898 & I \\
\hline II 3 & $o \Sigma \times 19 \ldots \ldots \ldots \ldots \ldots \ldots \ldots \ldots$ & 542 & +756 & I 898 & I \\
\hline II 4 & $\beta 94=6$ r Leporis......... & 545 & $-143 \mathrm{I}$ & 1903 & I \\
\hline II 5 & $\beta \mathrm{r} 6=3$ Monocerotis. & 557 & -1036 & 1903 & I \\
\hline I 6 & Skinner $2 \ldots$ & 6 & $-154 \mathrm{I}$ & I900 & I \\
\hline I 7 & $\Sigma 840(\mathrm{~B}$ and $\mathrm{C})$. & 6 & + io 46 & I 898 & I \\
\hline I 8 & $O \Sigma \mathrm{r} 32 \ldots$ & 6 & +380 & I 898 & I \\
\hline II 9 & Нu го6.... & 6 & - I I 40 & 1903 & I \\
\hline 120 & $\beta$ 1008 $=\eta$ Geminorum & 6 & +2232 & 1900 & I \\
\hline I 2 I & $\beta_{5} 66=21$ Monocerotis. . & 6 10 & -432 & 1900 & I \\
\hline 122 & $\beta$ Iо19....... & $6 \mathrm{II}$ & $-25 \mathrm{I}$ & 1900 & I \\
\hline 123 & Hu $\mathbf{1 0} 8 \ldots \ldots \ldots$ & 6 I3 & $-104 \mathrm{I}$ & 1903 & I \\
\hline 124 & $\begin{array}{r}\Sigma 919=1 \mathrm{I} \text { Monocerotis }(\mathrm{A} \text { and } \mathrm{B}) \ldots \\
(\mathrm{B} \text { and } \mathrm{C}) \ldots\end{array}$ & 624 & -658 & $\begin{array}{l}1898 \\
\text { r } 898\end{array}$ & $\begin{array}{l}\text { I } \\
\text { I }\end{array}$ \\
\hline 125 & Hu $43 \ldots \ldots \ldots \ldots$. & 629 & -122 & 1903 & I \\
\hline 126 & $\Sigma_{3 \mathbf{I} 7} \ldots \ldots \ldots \ldots \ldots$ & 636 & +950 & r 898 & I \\
\hline 127 & $\Sigma 955(\mathrm{~A}$ and $\mathrm{B}) \ldots \ldots$ & 636 & -754 & 1903 & r. \\
\hline 128 & 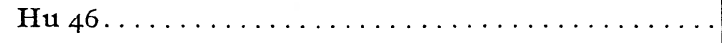 & 638 & $-12 \quad 12$ & 1903 & I \\
\hline 129 & A. G. Clark $\mathrm{I}=$ Sirius.. & $64 \mathrm{I}$ & - I6 35 & $\begin{array}{l}1899 \\
1900 \\
1901 \\
1902 \\
1903\end{array}$ & $\begin{array}{l}4 \\
5 \\
5 \\
4 \\
2\end{array}$ \\
\hline r 30 & $o \Sigma{ }_{15} 6 \ldots \ldots \ldots \ldots \ldots$ & 642 & $+\mathrm{I} 8 \mathrm{I} 8$ & I 898 & I \\
\hline I3 I & $\Sigma 963=14$ Lyncis..... & 644 & +5934 & I 899 & 2 \\
\hline 132 & $\beta 897=97$ Monocerotis. & 646 & -025 & I9OI & I \\
\hline I 33 & $O \Sigma 1_{59}=\mathrm{I}_{5}$ Lyncis.... & 649 & +5833 & I 899 & I \\
\hline I 34 & 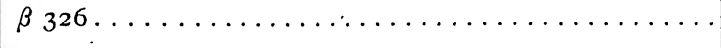 & $65^{\mathrm{I}}$ & +227 & I 898 & I \\
\hline I35 & $\varepsilon$ Canis Majoris.$\ldots \ldots \ldots \ldots \ldots \ldots \ldots \ldots \ldots \ldots \ldots$ & 655 & -2850 & 1900 & I \\
\hline I36 & 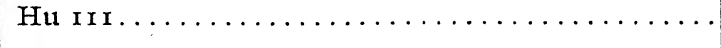 & 655 & - I I 52 & I903 & I \\
\hline I37 & $0 \Sigma \times 63(\mathrm{~A}$ and $\mathrm{B}) \ldots$ & 656 & $+\mathrm{II} 55$ & 1898 & $\mathbf{I}$ \\
\hline
\end{tabular}


TABLE XII-Continued.

\begin{tabular}{|c|c|c|c|c|c|}
\hline No. & Name. & $\begin{array}{l}\text { R. A. } \\
\text { I900. }\end{array}$ & Decl. 1900. & Year. & $\begin{array}{l}\text { No. of } \\
\text { Obs. }\end{array}$ \\
\hline 138 & Skinner $3 \ldots \ldots \ldots \ldots$ & $\begin{array}{lr}\mathrm{h} & \mathrm{m} \\
6 & 5^{8}\end{array}$ & $\begin{array}{r}\circ \\
-1738\end{array}$ & $\begin{array}{l}1896 \\
1900\end{array}$ & $\begin{array}{l}2 \\
1\end{array}$ \\
\hline I 39 & Skinner $4 \ldots \ldots \ldots \ldots$ & 71 & -1629 & $\begin{array}{l}1896 \\
1900\end{array}$ & $\begin{array}{l}2 \\
1\end{array}$ \\
\hline I 40 & 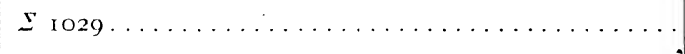 & 73 & $-43 I$ & 1905 & I \\
\hline $14 \mathrm{I}$ & $o \Sigma i 70 \ldots \ldots \ldots \ldots \ldots$ & 7 I 2 & +928 & 1898 & I \\
\hline 142 & Skinner $5 \ldots \ldots \ldots \ldots$ & $7 \mathrm{I} 5$ & -1637 & $\begin{array}{l}1896 \\
1900\end{array}$ & $\begin{array}{l}\text { I } \\
\text { I }\end{array}$ \\
\hline 143 & $\Sigma_{10} 74 \ldots \ldots \ldots \ldots \ldots \ldots$ & $7 \mathrm{I} 5$ & + o 35 & $\begin{array}{l}1898 \\
1902\end{array}$ & $\begin{array}{l}\text { I } \\
\text { I }\end{array}$ \\
\hline 144 & $\mathrm{Hu} 456 \ldots \ldots \ldots \ldots \ldots \ldots$ & 728 & $\begin{array}{llll}-17 & 18\end{array}$ & 1903 & I \\
\hline 145 & $\Sigma_{\text {IIIO }}=\alpha$ Geminorum. . . . . . . . . & 728 & +326 & 1900 & 3 \\
\hline 146 & $\Sigma_{1107} \ldots \ldots \ldots \ldots \ldots \ldots \ldots \ldots$ & 732 & +762 & I 899 & I \\
\hline 147 & 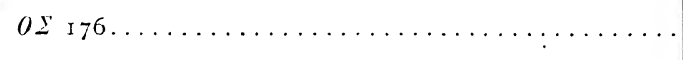 & 733 & +044 & 1898 & I \\
\hline 148 & Schaeberle $=$ Procyon $\ldots \ldots \ldots$ & 734 & +529 & $\begin{array}{l}1900 \\
1901 \\
1902\end{array}$ & $\begin{array}{l}5 \\
5 \\
3\end{array}$ \\
\hline 149 & Hu $457 \ldots \ldots \ldots \ldots \ldots \ldots$ & 735 & +2329 & 1903 & I \\
\hline 150 & $\Sigma$ II $26 \ldots \ldots \ldots \ldots \ldots \ldots$ & 735 & +528 & $1897^{\circ}$ & I \\
\hline $15 \mathrm{I}$ & $0 \Sigma$ I $79=\kappa$ Geminorum $\ldots \ldots \ldots \ldots$ & 738 & +2438 & I900 & 4 \\
\hline 152 & $\beta$ IOI $=9$ Argus $\ldots \ldots \ldots \ldots \ldots \ldots$ & 747 & -1338 & $\begin{array}{l}1898 \\
1900 \\
1901\end{array}$ & $\begin{array}{l}2 \\
3 \\
2\end{array}$ \\
\hline 153 & $\Sigma_{1}{ }_{157} \ldots \ldots \ldots \ldots$ & 750 & -232 & I 898 & I \\
\hline 154 & $O \Sigma \times 185 \ldots \ldots \ldots \ldots$ & $75^{2}$ & +124 & $\begin{array}{l}\text { I } 898 \\
\text { I } 899\end{array}$ & $\begin{array}{l}\mathbf{I} \\
2\end{array}$ \\
\hline I 55 & $\Sigma \times 1 \times 5 \ldots \ldots \ldots \ldots \ldots \ldots$ & 757 & +426 & 1899 & $\mathbf{x}$ \\
\hline 156 & $O \Sigma \Sigma_{1} 86 \ldots \ldots \ldots$ & 757 & +2633 & 1898 & $\mathbf{I}$ \\
\hline 157 & $o \Sigma \Sigma_{1} 8_{7} \ldots \ldots \ldots \ldots \ldots \ldots \ldots$ & 758 & +3219 & 1899 & 3 \\
\hline 158 & $\begin{array}{r}\beta 5_{81}(\mathrm{~A} \text { and } \mathrm{B}) \ldots \ldots \ldots \ldots \ldots \\
(\mathrm{AB} \text { and } \mathrm{C}) \ldots \ldots \ldots \ldots\end{array}$ & 759 & +1235 & $\begin{array}{l}1898 \\
1900 \\
1901 \\
1898 \\
1900 \\
1901\end{array}$ & $\begin{array}{l}3 \\
2 \\
2 \\
1 \\
2 \\
2\end{array}$ \\
\hline I 59 & 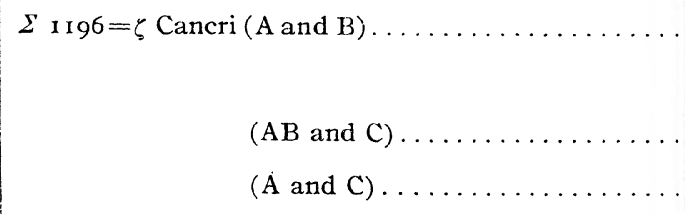 & 86 & +1757 & $\begin{array}{l}1897 \\
1898 \\
1899 \\
1900 \\
1897 \\
1900 \\
1899\end{array}$ & $\begin{array}{l}2 \\
1 \\
2 \\
2 \\
1 \\
2 \\
2\end{array}$ \\
\hline 160 & $\beta$ 102 $\ldots \ldots \ldots$ & 812 & -842 & 1903 & I \\
\hline 161 & $\beta 206 \ldots \ldots \ldots \ldots \ldots \ldots$ & $83 \mathrm{I}$ & -2446 & 1903 & $\mathrm{I}$ \\
\hline 162 & $\begin{array}{r}\text { Schiaparelli }=\varepsilon \text { Hydræ }(A \text { and } B) \ldots \ldots \ldots \ldots \ldots \\
(A B \text { and } C) \ldots \ldots \ldots \ldots\end{array}$ & $84 \mathrm{I}$ & +647 & $\begin{array}{l}1900 \\
1900 \\
1902\end{array}$ & $\begin{array}{l}\mathrm{I} \\
3 \\
\mathrm{I}\end{array}$ \\
\hline 163 & $\Sigma$ I280....... & 846 & $+71 \times 1$ & 1900 & 2 \\
\hline
\end{tabular}


TABLE XII-Continued.

\begin{tabular}{|c|c|c|c|c|c|}
\hline No. & Name. & $\begin{array}{l}\text { R. A. } \\
\text { I900. }\end{array}$ & Decl. 1900. & Year. & $\begin{array}{l}\text { No. of } \\
\text { Obs. }\end{array}$ \\
\hline 164 & 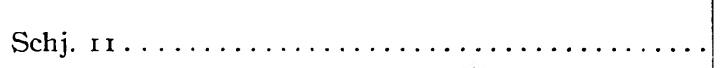 & $\begin{array}{lr}\mathrm{h} & \mathrm{m} \\
8 & 47\end{array}$ & - ${ }^{\circ}{ }^{\circ} 6^{\prime}$ & 1903 & I \\
\hline 165 & $\Sigma$ I $29 \mathrm{I}=\iota^{2}$ Cancri $\ldots$ & 848 & +3058 & 1897 & I \\
\hline I66 & $\beta 24 \ldots \ldots \ldots \ldots \ldots \ldots$ & 849 & -823 & 1903 & 3 \\
\hline 167 & 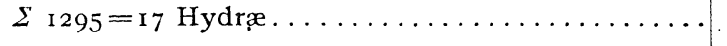 & $85 \mathrm{I}$ & -735 & 1903 & I \\
\hline 168 & 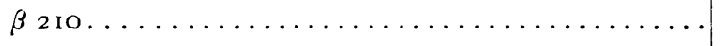 & 852 & $\begin{array}{ll}-17 & 3\end{array}$ & 1903 & I \\
\hline 169 & $O \Sigma \Sigma_{196}=\iota$ Ursæ Majoris $\ldots \ldots \ldots$ & 852 & +4826 & I900 & 2 \\
\hline I 70 & 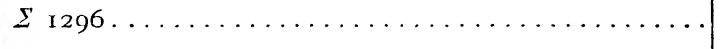 & 853 & +3520 & 1900 & I \\
\hline I 71 & $\Sigma{ }_{1306}=\sigma^{2}$ Ursæ Majoris . . . . . . & 92 & +6732 & $\begin{array}{l}1897 \\
1899\end{array}$ & $\begin{array}{l}\text { I } \\
6\end{array}$ \\
\hline 172 & 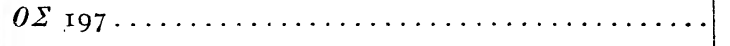 & 94 & $+32 \mathrm{I}$ & I 897 & 2 \\
\hline I 73 & $\Sigma 3121 \ldots \ldots \ldots \ldots$ & 9 I2 & +290 & $\begin{array}{l}1897 \\
1899\end{array}$ & $\begin{array}{l}3 \\
\mathbf{I}\end{array}$ \\
\hline I 74 & $\Sigma{ }_{1334=38 \text { Lyncis } \ldots \ldots \ldots \ldots \ldots}$ & $9 \times 3$ & +37 I4 & $\begin{array}{l}1897 \\
1900\end{array}$ & $\begin{array}{l}\mathbf{1} \\
2\end{array}$ \\
\hline I 75 & 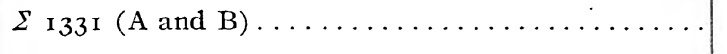 & 9 r 3 & +6 I 46 & I 897 & 3 \\
\hline 176 & $\Sigma$ I338=157 Lyncis . . . . . . . . . . & 9 I 5 & +3837 & $\begin{array}{l}1897 \\
1900\end{array}$ & I \\
\hline I 77 & 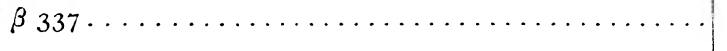 & $9 \mathrm{r} 8$ & -1728 & 1907 & I \\
\hline 178 & $0 \Sigma 200 \ldots \ldots$ & 918 & +520 & $\begin{array}{l}1897 \\
1900\end{array}$ & $\begin{array}{l}2 \\
2\end{array}$ \\
\hline $179^{\circ}$ & $0 \Sigma$ 201 $\ldots \ldots \ldots \ldots \ldots \ldots \ldots \ldots \ldots \ldots \ldots \ldots \ldots \ldots \ldots \ldots$ & 918 & +2820 & I 897 & I \\
\hline 180 & $\beta 338 \ldots \ldots \ldots \ldots \ldots \ldots \ldots \ldots \ldots$ & 918 & -154 & 1907 & $\mathbf{I}$ \\
\hline I 81 & $\Sigma$ I348=ix 6 Hydræ. . . & 919 & +647 & х 897 & I \\
\hline 182 & $\Sigma \Sigma_{1355} \ldots \ldots \ldots \ldots \ldots \ldots \ldots \ldots \ldots \ldots \ldots \ldots \ldots \ldots$ & 922 & +640 & 1897 & I \\
\hline 183 & Skinner $6 \ldots .$. & 922 & -1650 & $\begin{array}{l}1.900 \\
1903\end{array}$ & $\begin{array}{l}\mathrm{I} \\
2\end{array}$ \\
\hline 184 & $\Sigma{ }_{1356}=\omega$ Leonis............ & 923 & +930 & $\begin{array}{l}1897 \\
1899 \\
1900 \\
1902\end{array}$ & $\begin{array}{l}2 \\
2 \\
1 \\
2\end{array}$ \\
\hline 185 & $\beta 591 \ldots \ldots \ldots \ldots \ldots \ldots \ldots \ldots \ldots \ldots \ldots$ & 925 & $-24 \mathrm{I}$ & 1903 & I \\
\hline 186 & $\Sigma \mathrm{r} 374=30$ Leonis Minoris $\ldots \ldots \ldots \ldots \ldots$ & 935 & +3924 & 1900 & 2 \\
\hline 187 & 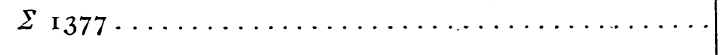 & 938 & +35 & 1902 & 2 \\
\hline I 88 & 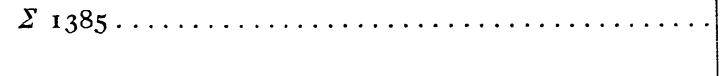 & 944 & +172 & $\begin{array}{l}1898 \\
1902\end{array}$ & I \\
\hline I 89 & 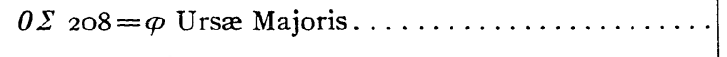 & 945 & +5432 & 1899 & 3 \\
\hline 190 & 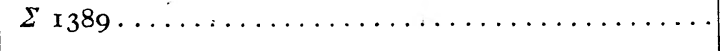 & 947. & +2727 & 1897 & 2 \\
\hline 191 & $\Sigma \mathrm{r} 386 \ldots \ldots \ldots \ldots$ & 947 & +6922 & $\begin{array}{l}1897 \\
1900\end{array}$ & $\begin{array}{l}2 \\
2\end{array}$ \\
\hline 192 & $\begin{array}{l}\text { A. Clark } 5=8 \text { Sextantis }(A \text { and } B) \ldots \ldots \ldots \ldots \ldots \\
(A B \text { and } C) \ldots \ldots \ldots \ldots\end{array}$ & 948 & -738 & $\begin{array}{l}1897 \\
1900 \\
1901 \\
1902 \\
1901\end{array}$ & $\begin{array}{l}\text { I } \\
3 \\
4 \\
3 \\
3\end{array}$ \\
\hline
\end{tabular}


TABLE XII-Continued.

\begin{tabular}{|c|c|c|c|c|c|}
\hline No. & Name. & $\begin{array}{l}\text { R. A. } \\
1900 .\end{array}$ & Decl. r goo. & Year. & $\begin{array}{l}\text { No. of } \\
\text { Obs. }\end{array}$ \\
\hline 193 & $\mathrm{H} 825 \ldots \ldots \ldots \ldots \ldots$ & $\begin{array}{cc}\text { h } & \text { m } \\
9 & 55\end{array}$ & $\begin{array}{rr}\circ \\
-1429\end{array}$ & 1907 & I \\
\hline I94 & $\Sigma$ r $406 \ldots \ldots \ldots \ldots \ldots \ldots \ldots \ldots$ & 10 0 & +3134 & 1899 & I \\
\hline 195 & 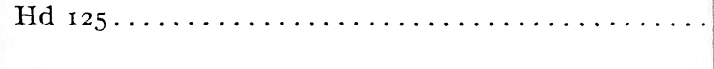 & 102 & -114 & $\begin{array}{l}1903 \\
1905\end{array}$ & $\begin{array}{l}2 \\
1\end{array}$ \\
\hline 196 & $\Sigma$ 1416........... & 10 7 & -1536 & 1903 & I \\
\hline 197 & $0 \Sigma 213 \ldots \ldots \ldots \ldots \ldots \ldots$ & 10 8 & +2755 & 1899 & I \\
\hline 198 & $0 \Sigma 215 \ldots \ldots \ldots \ldots \ldots \ldots$ & 10 II & +1814 & $\begin{array}{l}1897 \\
1899 \\
1902\end{array}$ & $\begin{array}{l}3 \\
\mathrm{I} \\
\mathrm{I}\end{array}$ \\
\hline 199 & 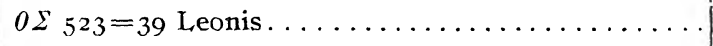 & 1012 & +2336 & 1899 & I \\
\hline 200 & 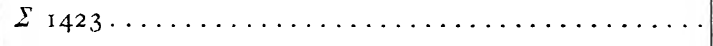 & IO 14 & $+21+$ & 1899 & I \\
\hline $20 \mathrm{I}$ & $\Sigma{ }_{1424}=\gamma$ Leonis . . . . . . . . . . . . . . . & 1014 & +2021 & $\begin{array}{l}1897 \\
1900\end{array}$ & $\begin{array}{l}\text { I } \\
3\end{array}$ \\
\hline 202 & $\begin{array}{r}\Sigma 1426=145 \text { Leonis }(\mathrm{A} \text { and } \mathrm{B}) \\
(\mathrm{AB} \text { and } \mathrm{C}) \\
\ldots \ldots \ldots \ldots \ldots \ldots \ldots\end{array}$ & IO 15 & +656 & $\begin{array}{l}1897 \\
1897\end{array}$ & $\begin{array}{l}3 \\
1\end{array}$ \\
\hline 203 & Hn $103 \ldots \ldots \ldots \ldots$ & 10 16 & $-155 \mathrm{I}$ & 1903 & 2 \\
\hline 204 & $\mathrm{Hn} \mathrm{ro}_{4} \ldots \ldots \ldots \ldots \ldots \ldots \ldots \ldots \ldots$ & 1016 & $\begin{array}{lll}-16 & 13\end{array}$ & 1907 & I \\
\hline 205 & $\beta{ }_{25}=$ Schj. I $6 \ldots \ldots$ & IO 17 & $-9 \times 6$ & $\begin{array}{l}1903 \\
1905\end{array}$ & $\begin{array}{l}3 \\
1\end{array}$ \\
\hline 206 & $\beta 219 \ldots \ldots \ldots$ & IO 17 & $-22 \quad 2$ & 1903 & 3 \\
\hline 207 & $0 \Sigma 216=150$ Leonis... & I0 17 & +1551 & r 899 & 3 \\
\hline 208 & $\mathrm{H} 43 \mathrm{I} \ldots \ldots \ldots \ldots$ & IO 18 & -1252 & 1903 & I \\
\hline 209 & $\Sigma 1429 \ldots \ldots \ldots$ & Io 19 & +258 & 1897 & 2 \\
\hline 210 & $\Sigma 1428 \ldots \ldots \ldots \ldots$ & 1020 & +538 & 1900 & 2 \\
\hline $2 \mathrm{II}$ & $O \Sigma 217 \ldots \ldots$ & 1021 & +1744 & I 899 & I \\
\hline 212 & $0 \Sigma 2 \times 8 \ldots \ldots \ldots$ & 1022 & +44 & 1899 & I \\
\hline 213 & $\Sigma 1439 \ldots \ldots \ldots \ldots \ldots$ & 10 25 & $+21 \quad 19$ & $\begin{array}{l}1897 \\
1900\end{array}$ & $\begin{array}{l}3 \\
1\end{array}$ \\
\hline 214 & $\Sigma$ I $441 \ldots \ldots \ldots \ldots \ldots \ldots$ & ro 26 & -77 & 1903 & 4 \\
\hline 215 & Skinner $14 \ldots \ldots \ldots \ldots \ldots$ & 1027 & -1553 & 1907 & I \\
\hline 216 & $\Sigma 1445 \ldots \ldots \ldots \ldots$ & 10 28 & -021 & $\begin{array}{l}1899 \\
1903\end{array}$ & I \\
\hline 217 & $\Sigma$ 1450 $=49$ Leonis... & 1030 & +910 & $\begin{array}{l}1897 \\
1900 \\
1902\end{array}$ & $\begin{array}{l}\text { I } \\
3 \\
\text { I }\end{array}$ \\
\hline 2 I 8 & $\beta 41, \ldots \ldots \ldots$ & Io $3 \mathrm{I}$ & $\begin{array}{ll}-26 & 9\end{array}$ & 1903 & 2 \\
\hline 219 & $\Sigma 1457 \ldots$ & 1034 & +615 & $\begin{array}{l}1897 \\
1900\end{array}$ & $\begin{array}{l}2 \\
2\end{array}$ \\
\hline 220 & Hn $108 \ldots$ & 10 34 & $\begin{array}{ll}-17 & 3\end{array}$ & 1903 & 3 \\
\hline $22 I$ & $O \Sigma 224 \ldots$ & & +922 & $\begin{array}{r}1899 \\
1900 \\
1902\end{array}$ & $\begin{array}{l}6 \\
\mathbf{I} \\
\mathbf{I}\end{array}$ \\
\hline
\end{tabular}


TABLE XII-Continued.

\begin{tabular}{|c|c|c|c|c|c|}
\hline No. & Name. & $\begin{array}{l}\text { R. A. } \\
\text { I9OO. }\end{array}$ & Decl. r 900. & Year. & $\begin{array}{l}\text { No. of } \\
\text { Obs. }\end{array}$ \\
\hline 222 & 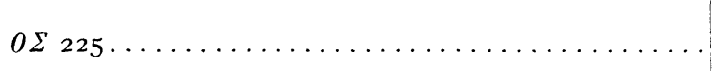 & $\begin{array}{rr}\text { h } & \mathrm{m} \\
\text { IO } & 35\end{array}$ & $\begin{array}{r}\circ \\
+1946\end{array}$ & I 900 & I \\
\hline 223 & $O \Sigma 227 \ldots$ & Io 36 & + II 16 & I 897 & 3 \\
\hline 224 & $\Sigma 1470 \ldots$ & $104 \mathrm{I}$ & $-5 \mathrm{I} 4$ & 1903 & 4 \\
\hline 225 & $0 \Sigma 228 \ldots$ & Io $4^{2}$ & $+2.3 \quad 6$ & 1897 & 2 \\
\hline 226 & $O \Sigma 229 \ldots \ldots \ldots$ & IO 42 & +4138 & I 897 & 3 \\
\hline 227 & $\beta 595 \ldots \ldots \ldots$ & IO 43 & -1426 & I 903 & I \\
\hline 228 & $\Sigma 1476 \ldots \ldots \ldots \ldots$ & ro 44 & -330 & 1903 & 5 \\
\hline 229 & $\beta$ III $\ldots \ldots \ldots \ldots \ldots \ldots$ & ro 46 & -834 & 1903 & 3 \\
\hline 230 & $0 \Sigma 230 \ldots \ldots \ldots \ldots \ldots \ldots \ldots$ & IO 49 & $+2 \mathrm{I} \quad 18$ & I900 & I \\
\hline $23 \mathrm{I}$ & 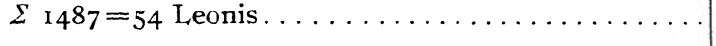 & 10 50 & +2.517 & 1900 & I \\
\hline 2.32 & $\Sigma$ 1500............ & I0 55 & -256 & $\begin{array}{l}\text { r } 897 \\
\text { r } 900 \\
1903\end{array}$ & $\begin{array}{l}2 \\
2 \\
5\end{array}$ \\
\hline 233 & Нु I. $77 \ldots \ldots \ldots \ldots \ldots \ldots \ldots \ldots \ldots \ldots$ & IO 57 & -159 & 1903 & 4 \\
\hline 234 & Howe $25 \ldots \ldots \ldots \ldots \ldots \ldots \ldots \ldots \ldots \ldots \ldots \ldots \ldots \ldots \ldots$ & I0 58 & -2659 & 1903 & 4 \\
\hline 235 & $\Sigma{ }_{1504} \ldots \ldots \ldots \ldots \ldots \ldots \ldots$ & $\mathbf{I} \mathbf{I}, \quad O$ & +4 II & $\begin{array}{l}1897 \\
1900\end{array}$ & $\begin{array}{l}2 \\
2\end{array}$ \\
\hline 236 & $\beta 599=65$ Leonis . . . . . . . . . . . & I I 2 & +230 & $\begin{array}{l}1900 \\
1901\end{array}$ & $\begin{array}{l}2 \\
2\end{array}$ \\
\hline 237 & $\Sigma{ }_{1517} \ldots \ldots \ldots \ldots \ldots$ & I I 8 & $+20+1$ & $\begin{array}{l}\text { I } 897 \\
\text { 1900 }\end{array}$ & $\begin{array}{l}3 \\
2\end{array}$ \\
\hline 238 & $\beta$ 9r6 $=3$ i Crateris $\ldots \ldots \ldots \ldots \ldots \ldots \ldots$ & $\begin{array}{ll} & \text { I I } \quad 9 \\
: & \end{array}$ & -1453 & $\begin{array}{l}1900 \\
1901 \\
1903\end{array}$ & $\begin{array}{l}2 \\
\mathrm{I} \\
\mathrm{I}\end{array}$ \\
\hline 239 & $0 \Sigma 232 \ldots \ldots \ldots \ldots \ldots \ldots$ & I I 10 & +387 & 1899 & I \\
\hline 240 & $\begin{array}{r}\beta 600=36 \text { Crateris }(\mathrm{A} \text { and } \mathrm{B}) \ldots \\
(\mathrm{AB} \text { and } \mathrm{C}) \ldots\end{array}$ & II 12 & -635 & $\begin{array}{l}1900 \\
1900\end{array}$ & $\begin{array}{l}2 \\
2\end{array}$ \\
\hline $24 \mathrm{I}$ & $0 \Sigma 233 \ldots \ldots \ldots \ldots \ldots \ldots$ & I I I 3 & $+67 \quad 14$ & 1900 & 2 \\
\hline 242 & $\Sigma{ }_{1523}=\xi$ Ursæ Majoris . . & I I I 3 & +326 & $\begin{array}{l}1897 \\
1900\end{array}$ & $\begin{array}{l}4 \\
4\end{array}$ \\
\hline 243 & $\Sigma 1_{527}=339$ Leonis. . . . . . . . . . . . . . & II I 4 & +1449 & 1900 & 4 \\
\hline 244 & $\Sigma \mathrm{I}_{534} \ldots \ldots \ldots \ldots \ldots \ldots$ & II 17 & +1844 & 1900 & 2 \\
\hline 245 & $\Sigma{ }_{1536}=:$ Leonis $\ldots \ldots \ldots$ & II I9 & + Ir 5 & 1900 & 4 \\
\hline 246 & $\beta 26 \ldots \ldots$ & II 19 & $-95^{2}$ & $\begin{array}{l}1900 \\
1903\end{array}$ & $\begin{array}{l}2 \\
4\end{array}$ \\
\hline 247 & 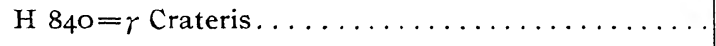 & I I 20 & -178 & 1903 & 4 \\
\hline 248 & $\Sigma{ }_{1543}=57$ Ursæ Majoris $\ldots \ldots \ldots \ldots \ldots \ldots$ & I I 24 & +3953 & 1900 & 3 \\
\hline 249 & Jacob $6 \ldots . .$. & I I 25 & -2355 & 1903 & 4 \\
\hline 250 & 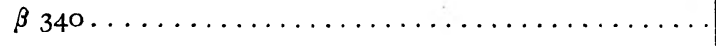 & I I 25 & +346 & 1900 & 2 \\
\hline $25 \mathrm{I}$ & $0 \Sigma 234 \ldots$ & I I 25 & +4150 & $\begin{array}{l}1897 \\
1899\end{array}$ & $\begin{array}{l}\mathbf{I} \\
3\end{array}$ \\
\hline
\end{tabular}


TABle XII-Continued.

\begin{tabular}{|c|c|c|c|c|c|}
\hline No. & Name. & $\begin{array}{l}\text { R. A. } \\
\text { I900. }\end{array}$ & Decl. I900. & Year. & $\begin{array}{l}\text { No. of } \\
\text { Obs. }\end{array}$ \\
\hline 252 & $O \Sigma 2.3 .5 \ldots \ldots \ldots$ & $\begin{array}{rr}\text { h } & \text { m } \\
\text { I I } & 27\end{array}$ & $\begin{array}{r}\circ \\
+6138\end{array}$ & $\begin{array}{l}1897 \\
1899\end{array}$ & $\begin{array}{l}\mathbf{I} \\
3\end{array}$ \\
\hline 253 & 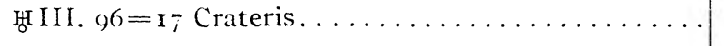 & II 27 & -2843 & 1903 & 3 \\
\hline 254 & $\Sigma_{15.52}=90$ I.eonis $(A$ and $B) \ldots \ldots \ldots \ldots \ldots$ & I I 30 & $+172 \mathrm{r}$ & $\begin{array}{l}1900 \\
1902\end{array}$ & $\begin{array}{l}2 \\
1\end{array}$ \\
\hline 2.55 & $\Sigma$ I5.55 $(\mathrm{A}$ and $\mathrm{B}) \ldots \ldots \ldots \ldots \ldots \ldots$ & I I 3 I & +2820 & $\begin{array}{l}1899 \\
1900\end{array}$ & $\begin{array}{l}2 \\
2\end{array}$ \\
\hline 2,56 & 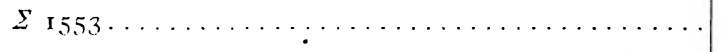 & II 3 I & $+564 \mathrm{r}$ & 1900 & 2 \\
\hline 2.57 & $\beta 456 \ldots \ldots \ldots \ldots \ldots \ldots \ldots$ & I I 32 & $-\mathrm{II} 48$ & 1900 & I. \\
\hline 2,58 & $\Sigma 1560 \ldots \ldots \ldots \ldots$ & I I 33 & - I 53 & 1903 & 4 \\
\hline 2.59 & $0 \leq 2.37 \ldots \ldots \ldots \ldots \ldots \ldots \ldots$ & I I 34 & $+4 \times 42$ & 1897 & 3 \\
\hline 260 & $\mathrm{H}_{4478}=\beta$ Hydræ. . . . . . . . . . . . . . . . & I I 48 & $-332 \mathrm{I}$ & 1903 & 2 \\
\hline 261 & $\beta 794(A$ and $B) \ldots \ldots \ldots \ldots$ & I I 48 & +7419 & I 899 & 2 \\
\hline 262 & $0 \leq 24 \mathrm{r} \ldots \ldots \ldots$ & II 5 I & $+36 \quad o$ & 1899 & I \\
\hline 26.3 & $\beta 918 \ldots \ldots \ldots \ldots$ & I I 52 & +3246 & 1900 & 2 \\
\hline 264 & $\mathrm{H} 448 \mathrm{r} \ldots \ldots \ldots \ldots \ldots \ldots \ldots$ & I I 52 & -2 I 59 & 1903 & 4 \\
\hline 26.5 & $o \Sigma 24, \ldots \ldots \ldots \ldots \ldots \ldots \ldots$ & I I 55 & +5357 & 1897 & I \\
\hline 266 & $\beta 457 \ldots \ldots \ldots \ldots$ & I I 56 & -2058 & I 900 & I \\
\hline 267 & $\Sigma \mathbf{r}_{593} \ldots \ldots \ldots$ & I I $5^{8}$ & - I 53 & $\begin{array}{l}1900 \\
1903\end{array}$ & $\begin{array}{l}2 \\
6\end{array}$ \\
\hline 268 & $\Sigma \mathrm{r}_{596}=2 \operatorname{com} \ldots \ldots \ldots \ldots \ldots$ & I I 59 & +22 & $\begin{array}{l}1900 \\
1902\end{array}$ & $\begin{array}{l}4 \\
\mathrm{I}\end{array}$ \\
\hline 269 & $\beta 458 \ldots \ldots \ldots$ & I I 59 & -2029 & I 900 & I \\
\hline 270 & $\beta 412 \ldots \ldots \ldots \ldots$ & I 23 & $-18 \quad 1$ & $\begin{array}{l}1903 \\
1904\end{array}$ & $\begin{array}{l}4 \\
\mathrm{I}\end{array}$ \\
\hline 271 & $\begin{array}{r}\Sigma I 604=59 \text { Virginis }(A \text { and } B) \ldots \\
\quad(A \text { and } C) \ldots\end{array}$ & I 24 & - II I 8 & $\begin{array}{l}1900 \\
1903 \\
1900\end{array}$ & $\begin{array}{l}2 \\
4 \\
2\end{array}$ \\
\hline 272 & $\Sigma+606 \ldots \ldots$ & 126 & +4027 & I 897 & 3 \\
\hline 27.3 & $S 6.34 \ldots \ldots \ldots$ & 12 6 & $-16 \quad 14$ & 1903 & 4 \\
\hline 274 & $\Sigma 1619 \ldots \ldots \ldots$ & I 2 IO & -642 & 1903 & 4 \\
\hline 27.5 & $\beta 920=17$ Corvi $\ldots$ & I 2 II & $-224^{8}$ & .1903 & 2 \\
\hline 276 & $\Sigma 1621 \ldots \ldots \ldots$ & I 2 II & +612 & 1897 & I \\
\hline 277 & $\beta 605 \ldots \ldots \ldots \ldots$ & 12 I 5 & -21.37 & 1903 & I \\
\hline 278 & $\Sigma{ }_{16} 69=68$ Comæ........ & 1219 & +268 & 1900 & 4. \\
\hline 279 & $\Sigma$ I641 $\ldots \ldots \ldots$ & 1220 & +3817 & I 897 & I \\
\hline 280 & $\beta 606=35$ Corvi. . . & I 22 I & -1424 & $\begin{array}{l}1899 \\
1900\end{array}$ & $\begin{array}{l}2 \\
1\end{array}$ \\
\hline $28 \mathrm{r}$ & Hn $13 \ldots \ldots \ldots \ldots \ldots \ldots$ & 1221 & -120 & 1903 & 4 \\
\hline 282 & $\Sigma$ I $643 \ldots \ldots \ldots \ldots \ldots \ldots \ldots \ldots$ & 1222 & +2735 & 1897 & $\mathbf{I}$ \\
\hline
\end{tabular}


TABLE XII-Continued.

\begin{tabular}{|c|c|c|c|c|c|}
\hline No. & Name. & $\begin{array}{l}\text { R. A. } \\
\text { I9O0. }\end{array}$ & Decl. 1900. & Year. & $\begin{array}{l}\text { No. of } \\
\text { Obs. }\end{array}$ \\
\hline 283 & $\beta 28 \ldots \ldots \ldots \ldots \ldots \ldots \ldots$ & $\begin{array}{rr}\mathbf{h} & \mathrm{m} \\
\mathbf{1 2} & 25\end{array}$ & $\begin{array}{rr}\circ \\
-1250\end{array}$ & 1903 & 4 \\
\hline 284 & $\Sigma 1647=191$ Virginis......... & 1225 & +1016 & $\begin{array}{l}\text { r } 897 \\
\text { r900 }\end{array}$ & $\begin{array}{l}1 \\
2\end{array}$ \\
\hline 285 & $\begin{array}{r}\beta 797(\mathrm{~A} \text { and } \mathrm{B}) \ldots \ldots \ldots \ldots \ldots \ldots \ldots \ldots \ldots \ldots \ldots \ldots \ldots \ldots \ldots \ldots \\
(\mathrm{AB} \text { and } \mathrm{C}) \ldots \ldots \ldots \ldots \ldots \ldots \ldots\end{array}$ & 1229 & +631 & $\begin{array}{l}1899 \\
1900 \\
1900\end{array}$ & $\begin{array}{l}2 \\
\text { I } \\
\text { I }\end{array}$ \\
\hline 286 & $\Sigma \mathrm{r} 658 \ldots \ldots$ & 1230 & +80 & $\begin{array}{l}1897 \\
1900\end{array}$ & $\begin{array}{l}\text { I } \\
2\end{array}$ \\
\hline 287 & 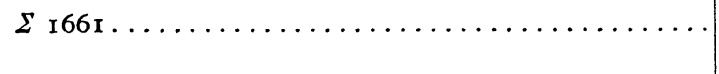 & $123 \mathrm{I}$ & $+\operatorname{Ir} 5^{8}$ & $\begin{array}{l}1897 \\
1900\end{array}$ & $\begin{array}{l}\text { I } \\
2\end{array}$ \\
\hline 288 & 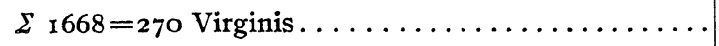 & 1236 & +923 & 1897 & 2 \\
\hline 289 & $\begin{array}{r}\Sigma \pm 669=58 \text { Corvi }(A \text { and B }) \ldots \ldots \ldots \ldots \ldots \\
(A \text { and C }) \ldots \ldots \ldots \ldots\end{array}$ & 1236 & $\begin{array}{c}-1228 \\
.\end{array}$ & $\begin{array}{l}1900 \\
1903 \\
1900\end{array}$ & $\begin{array}{l}2 \\
5 \\
1\end{array}$ \\
\hline 290 & $\Sigma 1670=r$ Virginis $(\mathrm{A}$ and $\mathrm{B}) \ldots$ & 1237 & -054 & $\begin{array}{l}1899 \\
1900 \\
1901 \\
1903\end{array}$ & $\begin{array}{l}2 \\
2 \\
2 \\
4\end{array}$ \\
\hline 291 & $\beta$ 924=31, Virginis $\ldots \ldots \ldots \ldots \ldots \ldots \ldots \ldots \ldots$ & 1237 & +721 & $\begin{array}{l}1900 \\
1901\end{array}$ & $\begin{array}{l}\mathbf{I} \\
2\end{array}$ \\
\hline 292 & 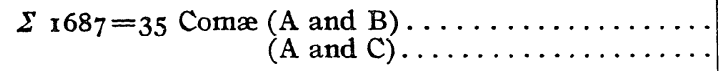 & 1248 & +2147 & $\begin{array}{l}1900 \\
1900\end{array}$ & $\begin{array}{l}\mathbf{I} \\
3\end{array}$ \\
\hline 293 & 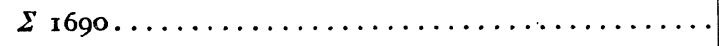 & I2 $5 \mathrm{I}$ & -419 & 1903 & 4 \\
\hline 294 & $0 \Sigma 256 \ldots \ldots \ldots \cdots \cdots$ & I2 5 I & -025 & $\begin{array}{l}1897 \\
1900\end{array}$ & $\begin{array}{l}\mathbf{I} \\
\mathbf{I}\end{array}$ \\
\hline 295 & 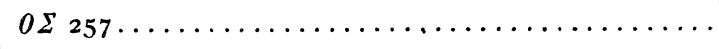 & 1252 & +469 & 1900 & 3 \\
\hline 296 & O. Stone $27 \ldots \ldots$. & 1253 & -1236 & - 1903 & 4 \\
\hline 297 & $\beta 926 \ldots \ldots \ldots \ldots \ldots$ & 1253 & -530 & 1901 & 2 \\
\hline 298 & 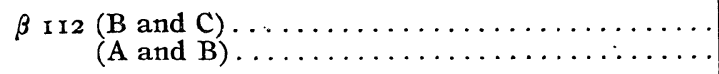 & 1256 & +1855 & $\begin{array}{l}\text { I90I } \\
\text { 190I }\end{array}$ & $\begin{array}{l}2 \\
2\end{array}$ \\
\hline 299 & $\Sigma 1707 \ldots \ldots \ldots \ldots \ldots$ & 1256 & +1624 & 1900 & 3 \\
\hline 300 & $\begin{array}{l}\beta 928(A \text { and } B) \ldots \ldots \\
\qquad(A \text { and } C) \ldots \ldots\end{array}$ & 1258 & -554 & $\begin{array}{l}1901 \\
1903 \\
1901\end{array}$ & $\begin{array}{l}\text { I } \\
3 \\
\text { I }\end{array}$ \\
\hline 301 & $0 \Sigma 260 \ldots \ldots$ & 133 & +2749 & 1899 & 2 \\
\hline 302 & $\Sigma_{1722}=179$ Comæ............. & 134 & +162 & 1900 & 2 \\
\hline 303 & $\Sigma_{1724}=\theta$ Virginis $(\mathrm{A}$ and $\mathrm{B}) \ldots \ldots \ldots$ & 135 & -50 & $1903^{-}$ & 4 \\
\hline 304 & $\Sigma \mathbf{r}_{728}=42$ Comæ.$\ldots \ldots \ldots \ldots \ldots \ldots$ & 135 & tr8 3 & 1899 & 3 \\
\hline 305 & 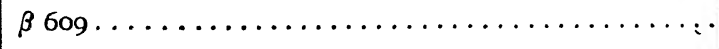 & 136 & -424 & 1901 & $\mathbf{I}$ \\
\hline 306 & 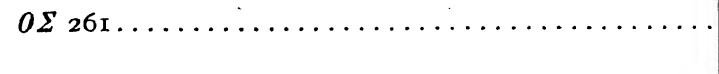 & 137 & +3237 & $\begin{array}{l}1897 \\
1900\end{array}$ & $\begin{array}{l}\text { I } \\
2\end{array}$ \\
\hline 307 & Sh $r 6 r=54$ Virginis $\ldots \ldots \ldots \ldots$ & 138 & $-18 \quad 18$ & 1903 & 2 \\
\hline 308 & $\beta 342 \ldots \ldots \ldots \ldots \ldots \ldots$ & 13 10 & $-18 \quad 23$ & I903 & 2 \\
\hline 309 & $\beta \mathbf{8 0 0}=20$ I Comæ. . . . . . . . & 1312 & +1733 & 1899 & I \\
\hline
\end{tabular}

$28167^{\circ}-\mathrm{VOL}, 6-\mathrm{ri}-\mathrm{V}$ 
TABLE XII-Continued.

\begin{tabular}{|c|c|c|c|c|c|}
\hline No. & Name. & $\begin{array}{l}\text { R. A. } \\
\text { I } 900 .\end{array}$ & Decl. r 900. & Year. & $\begin{array}{l}\text { No. of } \\
\text { Obs. }\end{array}$ \\
\hline 310 & $\Sigma 1738 \ldots \ldots$ & $\begin{array}{rr}\text { h } & \text { m } \\
13 & 18\end{array}$ & $\begin{array}{rr}\circ \\
-14 & 24\end{array}$ & 1903 & I \\
\hline 3 II & $\beta 237 \ldots \ldots \ldots$ & 1322 & +1454 & I 899 & I \\
\hline 312 & $O \Sigma 267 \ldots$ & I 324 & +7630 & I 899 & I \\
\hline $3 \mathrm{I} 3$ & 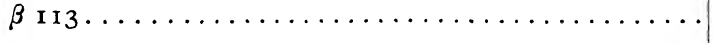 & 1324 & +120 & I 899 & I \\
\hline 314 & $0 \Sigma 269 \ldots \ldots \ldots \ldots \ldots \ldots$ & 1328 & +3525 & I 899 & 3 \\
\hline 315 & 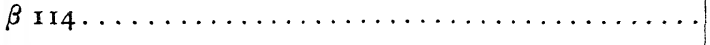 & 1329 & -86 & 1903 & 3 \\
\hline 316 & $\beta 932=550$ Virginis $(A$ and $B) \ldots \ldots$ & 1329 & -1242 & I 899 & 3 \\
\hline 317 & 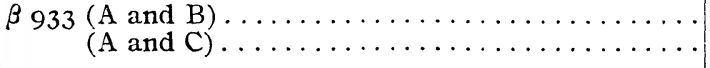 & 1330 & +3339 & $\begin{array}{l}1899 \\
1899\end{array}$ & I \\
\hline 318 & $\Sigma{ }_{1763}=8 \mathrm{r}$ Virginis $\ldots \ldots \ldots \ldots \ldots$ & 1332 & -722 & 1903 & 4 \\
\hline 319 & $\Sigma{ }_{17} 68=25$ Canum Venaticorum. . . . & 1333 & +3648 & 1899 & 2 \\
\hline 320 & $\Sigma$ I 77 I......... & I3 34 & +7017 & 1900 & 2 \\
\hline $32 \mathrm{I}$ & $\beta 612 \ldots \ldots$ & 1335 & $+\mathrm{Ir} \times 5$ & 1899 & 3 \\
\hline 322 & $\Sigma \mathrm{I}_{77} 6 \ldots$ & 1338 & +4644 & 1900 & 2 \\
\hline 323 & $\Sigma 1781 \ldots \ldots \ldots$ & 1341 & +537 & $\begin{array}{l}1897 \\
1899\end{array}$ & $\begin{array}{l}\text { I } \\
3\end{array}$ \\
\hline 324 & $\Sigma \Sigma_{17} 85 \ldots \ldots \ldots$ & 1345 & +2729 & $\begin{array}{l}1897 \\
1900\end{array}$ & $\begin{array}{l}\mathbf{I} \\
2\end{array}$ \\
\hline 325 & Skinner $\mathrm{r}_{5} \ldots \ldots \ldots$ & 1 347 & -1540 & 1907 & $\mathbf{I}$ \\
\hline 326 & Skinner $7 \ldots \ldots$ & I 349 & -1438 & 1900 & 2 \\
\hline 327 & $\Sigma I_{7} 88 \ldots \ldots \ldots$ & I 350 & -734 & 1903 & 4 \\
\hline 328 & $0 \Sigma 273 \ldots \ldots \ldots$ & I $35 \mathrm{I}$ & +547 & 1897 & $\mathbf{I}$ \\
\hline 329 & $\Sigma$ I $799 \ldots \ldots \ldots$ & 140 & -64 & 1903 & 2 \\
\hline 330 & $\Sigma 1802$ & I4 3 & -1227 & 1903 & I \\
\hline $33 \mathrm{I}$ & Hn $16 \ldots \ldots$ & I4 3 & -34 & 1903 & 2 \\
\hline 332 & Skinner $8 \ldots$. & I4 5 & -1420 & $\begin{array}{l}1900 \\
1903\end{array}$ & $\begin{array}{l}2 \\
1\end{array}$ \\
\hline 333 & $o \Sigma 278 \ldots \ldots \ldots \ldots$ & 148 & +4440 & I 899 & $\mathbf{I}$ \\
\hline 334 & $\Sigma 1813 \ldots$ & 148 & +552 & I 900 & 3 \\
\hline 335 & $\beta 939(\mathrm{~A}$ and $\mathrm{B}) \ldots \ldots$ & 149 & $\begin{array}{ll}-8 & 3\end{array}$ & I 899 & 2 \\
\hline 336 & 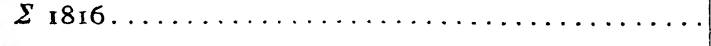 & $\times 49$ & +2934 & I900 & 2 \\
\hline 337 & $\Sigma \times 820 \ldots \ldots \ldots \ldots$ & 14 I0 & +5548 & $\begin{array}{l}\text { I } 897 \\
\text { I } 900\end{array}$ & $\begin{array}{l}1 \\
3\end{array}$ \\
\hline 338 & 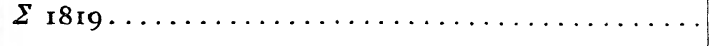 & 1410 & +336 & 1897 & I \\
\hline 339 & $0 \Sigma 28 \mathrm{r} \ldots \ldots \ldots \ldots \ldots$ & 1415 & +92 & 1897 & I \\
\hline 340 & 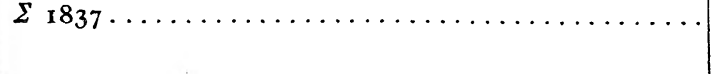 & 1419 & - II 13 & $\begin{array}{l}1897 \\
1903\end{array}$ & $\begin{array}{l}\text { I } \\
\text { I }\end{array}$ \\
\hline $34 \mathrm{I}$ & 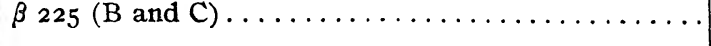 & 1420 & -1931 & 1903 & $\mathbf{I}$ \\
\hline 342 & $\Sigma \mathrm{I} 842 \ldots$ & 1422 & +48 & r897 & $\mathbf{r}$ \\
\hline
\end{tabular}


TABLE XII-Continued.

\begin{tabular}{|c|c|c|c|c|c|}
\hline No. & Name. & $\begin{array}{l}\text { R. A. } \\
\text { I } 900 .\end{array}$ & Decl. 1900. & Year. & $\begin{array}{l}\text { No. of } \\
\text { Obs. }\end{array}$ \\
\hline 343 & $\beta 462(A$ and $B) \ldots \ldots \ldots \ldots \ldots$ & $\begin{array}{ll}\text { h } & \text { m } \\
\text { I } 4 & 25\end{array}$ & $\begin{array}{rr}\circ \\
-316\end{array}$ & 1903 & I \\
\hline 344 & 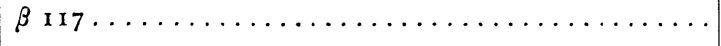 & 1426 & $-I_{5}$ II & 1899 & I \\
\hline 345 & $\Sigma 1858 \ldots$ & 1430 & $+36 \mathrm{I}$ & $\begin{array}{l}\text { I } 900 \\
\text { I9OI }\end{array}$ & $\begin{array}{l}3 \\
1\end{array}$ \\
\hline 346 & 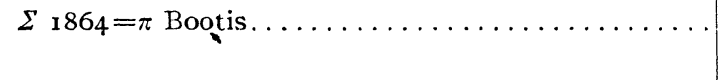 & 1436 & $+165 \mathrm{I}$ & $\begin{array}{l}\text { 1 } 899 \\
\text { I } 900\end{array}$ & $\begin{array}{l}1 \\
2\end{array}$ \\
\hline 347 & 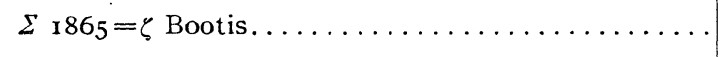 & 1436 & +149 & I 899 & I \\
\hline 348 & $\Sigma 1866 \ldots \ldots \ldots$ & 1437 & +957 & I 897 & I \\
\hline 349 & $\beta 807 \ldots \ldots \ldots \ldots \ldots \ldots$ & I 438 & -623 & I gor & I \\
\hline 350 & 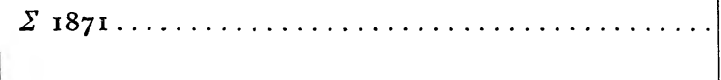 & 1438 & +5 I 50 & $\begin{array}{l}1897 \\
1900\end{array}$ & $\begin{array}{l}1 \\
2\end{array}$ \\
\hline $35 \mathrm{I}$ & $\Sigma \mathrm{I} 877=\varepsilon$ Bootis $\ldots \ldots \ldots \ldots \ldots \ldots \ldots \ldots \ldots \ldots \ldots \ldots$ & I 4 I & +2730 & $\begin{array}{l}1899 \\
1900\end{array}$ & $\begin{array}{l}3 \\
3\end{array}$ \\
\hline $35^{2}$ & 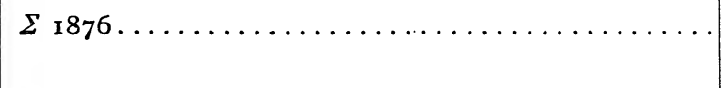 & $144 \mathrm{I}$ & -658 & $\begin{array}{l}\text { I } 897 \\
1903\end{array}$ & $\begin{array}{l}\text { I } \\
\text { I }\end{array}$ \\
\hline 353 & 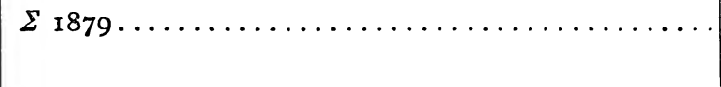 & 1441 & +10 5 & $\begin{array}{l}1897 \\
1899\end{array}$ & $\begin{array}{l}2 \\
5\end{array}$ \\
\hline 354 & 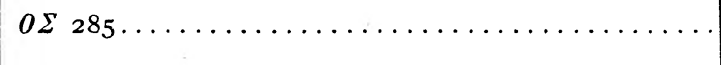 & $r_{4} 42$ & +4248 & 1899 & 2 \\
\hline 355 & $\beta 346=23$ Libræ. $\ldots \ldots \ldots \ldots \ldots \ldots \ldots \ldots \ldots \ldots \ldots \ldots \ldots \ldots$ & 1443 & -1655 & I90I & $\mathbf{I}$ \\
\hline 356 & 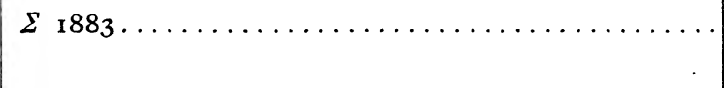 & I4 44 & +622 & $\begin{array}{l}1897 \\
1901\end{array}$ & I \\
\hline 357 & $\Sigma_{1884}=286$ Bootis. $\ldots \ldots \ldots \ldots \ldots \ldots \ldots \ldots \ldots$ & I4 44 & +2447 & 1897 & I \\
\hline 358 & $\Sigma 1888=\xi$ Bootis $\ldots \ldots \ldots \ldots \ldots$ & $\cdot 1447$ & +1931 & $\begin{array}{l}1897 \\
1899 \\
1901 \\
1902\end{array}$ & $\begin{array}{l}2 \\
8 \\
1 \\
3\end{array}$ \\
\hline 359 & $o \Sigma 287 \ldots \ldots \ldots \ldots \ldots$ & 1448 & +4520 & 1897 & I \\
\hline 360 & $o \Sigma 288 \ldots \ldots \ldots$ & 1449 & +167 & $\begin{array}{l}\text { I } 897 \\
1900\end{array}$ & $\begin{array}{l}\text { I } \\
3\end{array}$ \\
\hline $36 r$ & 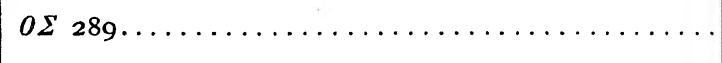 & 1452 & +3242 & 1899 & I \\
\hline 362 & $\beta 239=59$ Hydræ. . . . . . . & I 4.53 & $-27 \quad 15$ & 1901 & I \\
\hline 363 & 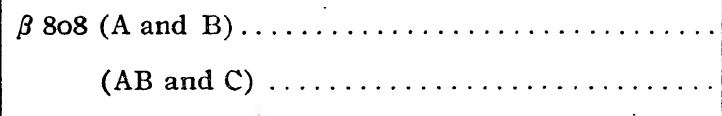 & 1453 & $-8 I_{7}$ & $\begin{array}{l}\text { I } 901 \\
\text { I } 901\end{array}$ & I \\
\hline 364 & 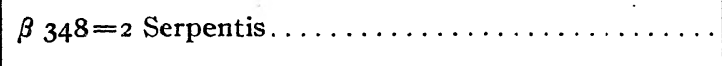 & 1457 & +015 & 1899. & 2 \\
\hline 365 & 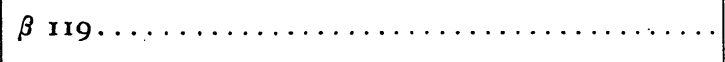 & I5 o & -638 & I903 & 3 \\
\hline 366 & 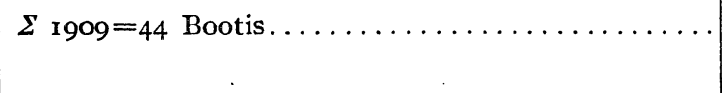 & I5 0 & +483 & $\begin{array}{l}1899 \\
1900\end{array}$ & $\begin{array}{l}2 \\
3\end{array}$ \\
\hline 367 & 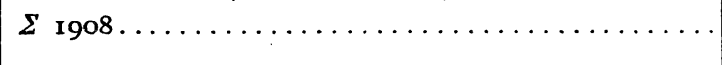 & I5 $\mathbf{I}$ & $+345 \mathrm{I}$. & 1897 & 1 \\
\hline 368 & 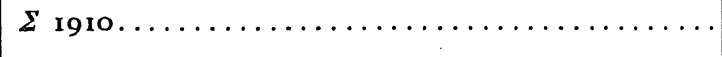 & 15.3 & +937 & 1899 & I \\
\hline 369 & 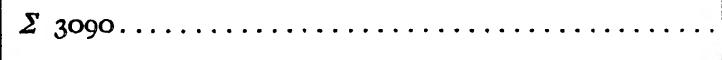 & I5 4 & -036 & 1903 & 3 \\
\hline 370 & 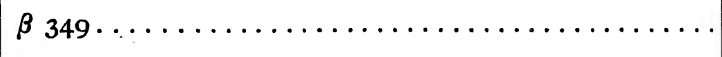 & I5 4 & +24 & IgOI & I \\
\hline
\end{tabular}


TABLE XII-Continued.

\begin{tabular}{|c|c|c|c|c|c|}
\hline No. & Name. & $\begin{array}{l}\text { R. A. } \\
\text { I90o. }\end{array}$ & Decl. 1900. & Year. & $\begin{array}{l}\text { No. of } \\
\text { Obs. }\end{array}$ \\
\hline 371 & 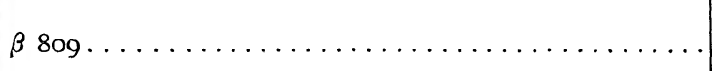 & $\begin{array}{rr}\text { h } & \text { m } \\
\text { I5 } & 4\end{array}$ & $\begin{array}{rr}\circ & \prime \\
-22 & 21\end{array}$ & 1903 & I \\
\hline 372 & 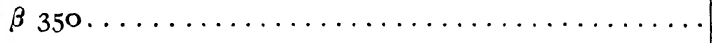 & I5 IO & $\begin{array}{lll}-27 & 14\end{array}$ & I9O3 & I \\
\hline 373 & $O \Sigma 294 \ldots \ldots \ldots \ldots \ldots$ & I5 IO & +5625 & 1897 & I \\
\hline 374 & $\Sigma 1926 \ldots \ldots \ldots \ldots$ & I5 II & +3840 & 1899 & I \\
\hline 375 & 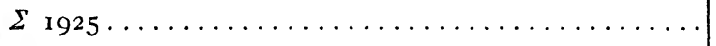 & 1512 & -755 & I903 & 2 \\
\hline 376 & 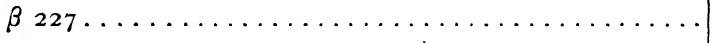 & 1513 & -2354 & I9O3 & 2 \\
\hline 377 & $\beta 228 \ldots \ldots \ldots \ldots$ & ${ }^{5} 14$ & -2354 & I903 & I \\
\hline 378 & $\Sigma 1934 \ldots \ldots$ & 1514 & +44 10 & 1900 & 2 \\
\hline 379 & $\Sigma$ I932 $=$ I Coronæ $\ldots \ldots \ldots$ & I5 14 & +2712 & 1897 & 2 \\
\hline 380 & 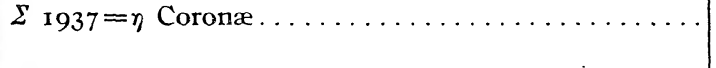 & 1519 & +3039 & $\begin{array}{l}1897 \\
1899\end{array}$ & $\begin{array}{l}2 \\
2\end{array}$ \\
\hline $38 \mathrm{r}$ & $\Sigma$ I938 $=\mu^{2}$ Bootis $\ldots \ldots \ldots \ldots$ & I $52 \mathrm{I}$ & +3742 & $\begin{array}{l}1897 \\
1899\end{array}$ & $\begin{array}{l}2 \\
1\end{array}$ \\
\hline 382 & 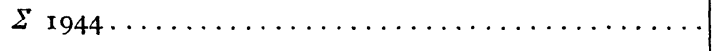 & 1523 & +627 & 1897 & I \\
\hline 383 & $0 \Sigma 296 \ldots \ldots \ldots \ldots \ldots \ldots$ & 1523 & $+442 \mathrm{I}$ & 1900 & 2 \\
\hline 384 & $\beta 33 \ldots \ldots \ldots \ldots$. & 1526 & - I 239 & 1903 & 2 \\
\hline 385 & $\Sigma \mathrm{r} 956 \ldots \ldots \ldots \ldots$ & I5 30 & +429 & 1900 & 2 \\
\hline 386 & $\Sigma \mathrm{r} 954=\delta$ Serpentis .. & I $5 \quad 30$ & tio 52 & $\begin{array}{l}1899 \\
1900 \\
1902\end{array}$ & $\begin{array}{l}1 \\
3 \\
2\end{array}$ \\
\hline 387 & $0 \Sigma 298 \ldots \ldots \ldots$ & 1532 & +408 & $\begin{array}{l}1897 \\
1900\end{array}$ & $\begin{array}{l}2 \\
2\end{array}$ \\
\hline 388 & $0 \Sigma 299 \ldots \ldots \ldots \ldots$ & 1532 & $+64 \mathrm{r} 4$ & $\begin{array}{l}1897 \\
1900\end{array}$ & $\begin{array}{l}\text { I } \\
2\end{array}$ \\
\hline 389 & $\beta \mp 22 \ldots \ldots \ldots \ldots \ldots$ & 1534 & -1927 & 1903 & 2 \\
\hline 390 & Howe $37 \ldots \ldots \ldots$. & 1535 & -1430 & 1907 & I \\
\hline 391 & $\Sigma_{1965}=\zeta$ Coronæ..... & 1536 & $+365^{8}$ & 1900 & 3 \\
\hline 392 & $\beta 35 \ldots \ldots \ldots \ldots \ldots \ldots \ldots$ & 1537 & -1542 & 1903 & 2 \\
\hline 393 & $\Sigma$ r967 $=r$ Coronæ......... & I5 39 & +2637 & $\begin{array}{l}\text { I } 897 \\
\text { I } 899\end{array}$ & $\begin{array}{l}2 \\
2\end{array}$ \\
\hline 394 & $\Sigma 1969 \ldots \ldots$ & I5 39 & +6018 & I 899 & I \\
\hline 395 & $\Sigma 1974 \ldots \ldots \ldots \ldots$ & I 544 & $-25^{6}$ & 1903 & 2 \\
\hline 396 & Skinner $9 \ldots \ldots \ldots \ldots \ldots$ & 1547 & -1656 & $\begin{array}{l}1895 \\
1900\end{array}$ & $\begin{array}{l}\mathbf{I} \\
3\end{array}$ \\
\hline 397 & $\beta 810 \ldots \ldots \ldots$ & 1548 & +4246 & I 899 & 2 \\
\hline 398 & $\Sigma 1985 \ldots \ldots$ & I $55^{1}$ & - I 52 & $\begin{array}{l}1899 \\
1900 \\
1903\end{array}$ & $\begin{array}{l}\text { I } \\
2 \\
\text { I }\end{array}$ \\
\hline 399 & 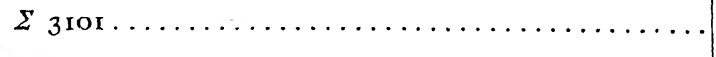 & I5 54 & -247 & I9O3 & I \\
\hline 400 & $\beta 623 \ldots \ldots$ & & $-64 \mathrm{I}$ & 1903 & 2. \\
\hline
\end{tabular}


TABLE, XII-Continued.

\begin{tabular}{|c|c|c|c|c|c|}
\hline No. & Name. & $\begin{array}{l}\text { R. A. } \\
\text { I9Oo. }\end{array}$ & Decl. 1900. & Year. & $\begin{array}{l}\text { No. of } \\
\text { Obs. }\end{array}$ \\
\hline 401 & $0 \Sigma 303 \ldots \ldots \ldots \ldots \ldots$ & $\begin{array}{cr}\mathrm{h} & \mathrm{m} \\
\mathrm{I} 5 & 5^{6}\end{array}$ & $\begin{array}{r}\circ \\
+1333\end{array}$ & $\begin{array}{l}1897 \\
1899 \\
1902\end{array}$ & $\begin{array}{l}\text { I } \\
\text { I } \\
2\end{array}$ \\
\hline 402 & $\begin{array}{r}\Sigma 1998=\xi \text { Scorpii }(\mathrm{A} \text { and } \mathrm{B}) \ldots \ldots \ldots \ldots \ldots \ldots \\
(\mathrm{AB} \text { and } \mathrm{C}) \ldots \ldots \ldots \ldots \ldots\end{array}$ & 1559 & $\begin{array}{ll}- \text { II } & 6\end{array}$ & $\begin{array}{l}1898 \\
1899 \\
1899\end{array}$ & $\begin{array}{l}2 \\
2 \\
2\end{array}$ \\
\hline 403 & 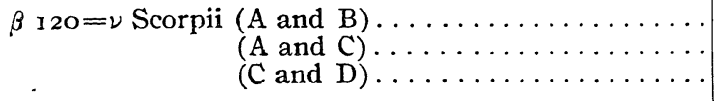 & 166 & $-19 \times 2$ & $\begin{array}{l}1899 \\
1899 \\
1899\end{array}$ & $\begin{array}{l}\text { I } \\
\text { I }\end{array}$ \\
\hline 404 & 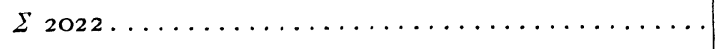 & 169 & +2656 & I 899 & I \\
\hline 405 & $\Sigma 202 \mathrm{I}=49$ Serpentis $\ldots \ldots \ldots \ldots \ldots$ & I6 9 & +1348 & $\begin{array}{l}1900 \\
1902\end{array}$ & $\begin{array}{l}3 \\
4\end{array}$ \\
\hline 406 & 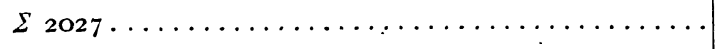 & 1610 & +431 & х 897 & I \\
\hline 407 & $\Sigma 2032=\sigma$ Coron $x(\mathrm{~A}$ and $\mathrm{B})$ & 16 II & $+34 \quad 7$ & $\begin{array}{l}1897 \\
1900\end{array}$ & $\begin{array}{l}1 \\
2\end{array}$ \\
\hline 408 & $\Sigma 2026 \ldots \ldots \ldots \ldots$ & I6 II & +737 & I.897 & 3 \\
\hline 409 & $0 \Sigma 309 \ldots \ldots \ldots \ldots$ & I6 I6 & +4154 & r 897 & $\mathbf{I}$ \\
\hline 410 & $\Sigma 2041 \ldots \ldots \ldots \ldots$ & I6 I7 & +127 & I 897 & $\mathbf{I}$ \\
\hline $4 \mathrm{II}$ & $\Sigma 2044 \ldots \ldots \ldots \ldots \ldots$ & I6 21 & +3716 & I900 & 2 \\
\hline 412 & $\Sigma{ }_{2054}=99$ Draconis. . . . . . . . . . . . . & I6 22 & $+6 \mathrm{r} 55$ & 1900 & 2 \\
\hline $4 \mathrm{I} 3$ & $\alpha$ Scorpii............ & 1623 & $-26 \quad 13$ & $\begin{array}{l}1899 \\
1900 \\
1902\end{array}$ & $\begin{array}{l}1 \\
2 \\
2\end{array}$ \\
\hline 414 & 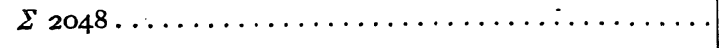 & 1623 & -754 & 1903 & I \\
\hline 415 & $\Sigma 2049 \ldots \ldots \ldots$ & 1624 & +2612 & ז896 & I \\
\hline 416 & $\Sigma 2052=71$ Herculis $\ldots \ldots \ldots \ldots \ldots$ & I6 24 & +1837 & $\begin{array}{l}1897 \\
1900\end{array}$ & $\begin{array}{l}2 \\
2\end{array}$ \\
\hline 417 & 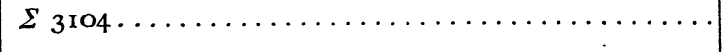 & 1625 & -1420 & 1907 & I \\
\hline 418 & $\Sigma 2055=\lambda$ Ophiuchi $\ldots \ldots \ldots \ldots$ & 1626 & +2 i2 & $\begin{array}{l}1896 \\
1899 \\
1900\end{array}$ & $\begin{array}{l}\text { I } \\
\text { I } \\
3\end{array}$ \\
\hline $4 \mathrm{I} 9$ & 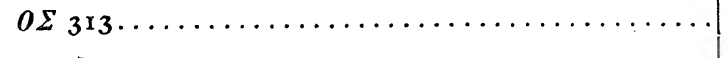 & 1629 & +4020 & I 897 & I \\
\hline 420 & $o \Sigma 3_{14} \ldots \ldots \ldots \ldots$ & I6 35 & +2040 & I 897 & $\mathbf{I}$ \\
\hline $42 I$ & $\Sigma 2084=\zeta$ Herculis. . . . . . . . . . & 1638 & +3147 & I 899 & 2 \\
\hline 422 & $\Sigma 2091 \ldots \ldots \ldots \ldots \ldots \ldots$ & 1639 & +4123 & 1897 & 2 \\
\hline 423 & Skinner ro........... & 1640 & -17 10 & $\begin{array}{l}1895 \\
1900\end{array}$ & $\begin{array}{l}2 \\
3\end{array}$ \\
\hline 424 & 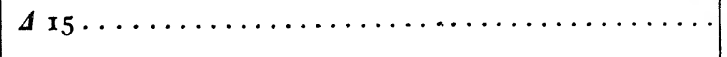 & 1641 & +4340 & 1899 & 2 \\
\hline 425 & 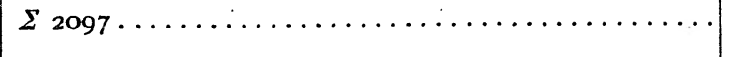 & I6 $4 \mathrm{I}$ & +3555 & I900 & 2 \\
\hline 426 & 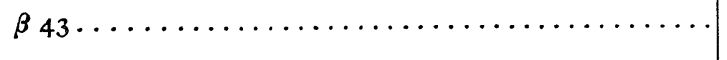 & I6 43 & +255 & 1898 & $\mathbf{I}$ \\
\hline 427 & $\Sigma 2107=167$ Herculis $\ldots \ldots \ldots \ldots \ldots \ldots \ldots \ldots$ & I6 48 & +2850 & I 899 & $\mathbf{I}$ \\
\hline $428^{\circ}$ & 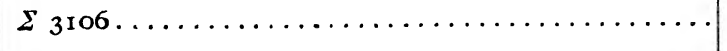 & I6 50 & $\begin{array}{ll}-5 & 0\end{array}$ & 1903 & 4 \\
\hline
\end{tabular}


TABLE XII-Continued.

\begin{tabular}{|c|c|c|c|c|c|}
\hline No. & Name. & $\begin{array}{l}\text { R. A. } \\
\text { Igoo. }\end{array}$ & Decl. 1900. & Year. & $\begin{array}{l}\text { No. of } \\
\text { Obs. }\end{array}$ \\
\hline 429 & $0 \Sigma \Sigma_{318 \ldots \ldots \ldots}$ & $\begin{array}{rr}h & m \\
16 & 52\end{array}$ & $\begin{array}{r}\circ \\
+14 \\
\end{array}$ & 1900 & I \\
\hline 430 & $0 \Sigma 319 \ldots$ & I6 54 & +1518 & 1897 & I \\
\hline $43 \mathrm{I}$ & $\Sigma 3107 \ldots \ldots \ldots \ldots$ & I6 54 & +47 & 1902 & I \\
\hline 432 & $0 \Sigma 322 \ldots \ldots$ & 1656 & $+37 \quad 4$ & 1897 & I \\
\hline 433 & 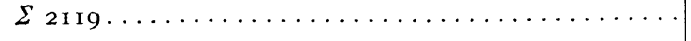 & $17 \mathrm{I}$ & -1348 & 1903 & 6 \\
\hline 434 & $\Sigma 2130=\mu$ Draconis $(\mathrm{A}$ and $\mathrm{B}) \ldots$ & 173 & +5436 & 1900 & 2 \\
\hline 435 & $0 \Sigma \Sigma_{324} \ldots \ldots \ldots \ldots \ldots \ldots \ldots$ & 174 & +3120 & 1897 & I \\
\hline 436 & $\beta$ II $8=\eta$ Ophiuchi $(A$ and $B) \ldots$ & 175 & -1536 & I 899 & I \\
\hline 437 & $\beta 124 \ldots \ldots$ & I 75 & -038 & 1903 & 3 \\
\hline 438 & $\Sigma 2132 \ldots \ldots \ldots \ldots \ldots$ & 177 & $-35^{6}$ & 1903 & 3 \\
\hline 439 & $\Sigma 2135 \ldots \ldots \ldots \ldots \ldots \ldots$ & 178 & +2121 & I 900 & 2 \\
\hline 440 & $0 \Sigma 325 \ldots \ldots \ldots \ldots \ldots$ & I7 8 & +752 & I 897 & I \\
\hline $44 \mathrm{I}$ & $\Sigma 2140=\alpha$ Herculis $(\mathrm{A}$ and $\mathrm{B}) \ldots$ & 1710 & +1430 & $\begin{array}{l}1899 \\
1900\end{array}$ & $\begin{array}{l}\mathrm{I} \\
2\end{array}$ \\
\hline 442 & $O \Sigma 328=68$ Herculis & I7 14 & +3312 & I 897 & I \\
\hline 443 & $\beta 628 \ldots \ldots \ldots$ & I7 I5 & +3246 & I 898 & I \\
\hline 444 & $\beta 959 \ldots \ldots \ldots \ldots$ & $17 \mathbf{1 7}$ & +56 & 1898 & 2 \\
\hline 445 & 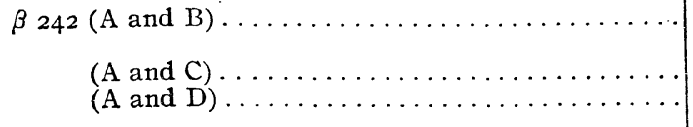 & I7 18 & -II 36 & $\begin{array}{l}\text { I } 898 \\
\text { r } 903 \\
\text { I } 898 \\
\text { I } 898\end{array}$ & $\begin{array}{l}\text { I } \\
\text { I } \\
\text { I } \\
\text { I }\end{array}$ \\
\hline 446 & $\beta 46 \ldots \ldots \ldots \ldots \ldots$ & 17 I9 & +1330 & I 898 & 2 \\
\hline 447 & 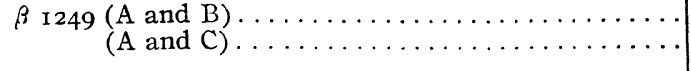 & 1720 & +5357 & $\begin{array}{l}\text { I } 898 \\
\text { I } 898\end{array}$ & $\begin{array}{l}\text { I } \\
\text { I }\end{array}$ \\
\hline 448 & 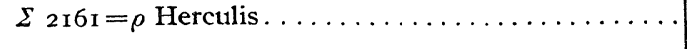 & 1720 & +3714 & I899 & I \\
\hline 449 & $\Sigma 2165=281$ Herculis.... & 1722 & +2932 & 1900 & 2 \\
\hline $45^{\circ}$ & $\Sigma 2171 \ldots \ldots \ldots$ & 1724 & -955 & $\begin{array}{l}1897 \\
1903\end{array}$ & $\begin{array}{l}\mathrm{I} \\
3\end{array}$ \\
\hline $45^{1}$ & $\Sigma 2173=221$ Ophiuchi. & 1725 & -059 & $\begin{array}{l}1896 \\
1899 \\
1903\end{array}$ & $\begin{array}{l}3 \\
1 \\
5\end{array}$ \\
\hline 452 & $0 \Sigma 331 \ldots \ldots \ldots \ldots \ldots$ & I 727 & +254 & I 897 & 2 \\
\hline 453 & $\Sigma 2190 \ldots \ldots \ldots \ldots \ldots$ & 1732 & $+2 I \quad 4$ & 1900 & 2 \\
\hline 454 & $\beta 960 \ldots \ldots \ldots \ldots \ldots \ldots \ldots \ldots \ldots \ldots \ldots \ldots$ & 1733 & -16 & $1898^{\circ}$ & 2 \\
\hline 455 & $\Sigma 2192=315$ Herculis.... & I7 36 & +29 I8 & I 900 & I \\
\hline 456 & Hu I $84 \ldots \ldots \ldots$ & I7 36 & -1540 & $\begin{array}{l}1895 \\
1900\end{array}$ & $\begin{array}{l}2 \\
3\end{array}$ \\
\hline 457 & 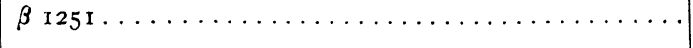 & I7 37 & +160 & 1898 & $\mathbf{I}$ \\
\hline $45^{8}$ & $\Sigma 2218 \ldots \ldots \ldots$ & I 740 & +6343 & 1900 & 2 \\
\hline
\end{tabular}


TABLE XII-Continued.

\begin{tabular}{|c|c|c|c|c|c|}
\hline No. & Name. & $\begin{array}{l}\text { R. A. } \\
\text { I9Oo. }\end{array}$ & Decl. 1900. & Year. & $\begin{array}{l}\text { No. of } \\
\text { Obs. }\end{array}$ \\
\hline 459 & 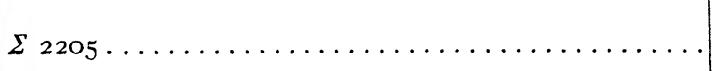 & $\begin{array}{rr}\mathrm{h} & \mathrm{m} \\
\mathrm{r} & 4 \mathrm{r}\end{array}$ & $\begin{array}{r}\circ \\
+1745\end{array}$ & 1900 & 2 \\
\hline 460 & A. Clark $7=\mu$ Herculis $(B$ and $C)$ & I 743 & +2747 & $\begin{array}{l}\mathbf{1} 897 \\
1906\end{array}$ & $\begin{array}{l}3 \\
5\end{array}$ \\
\hline $46 \mathrm{I}$ & 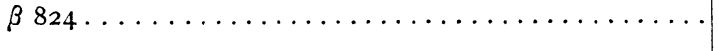 & I 744 & - I 50 & $\begin{array}{l}1898 \\
1903\end{array}$ & I \\
\hline 462 & $0 \Sigma 338 \ldots \ldots \ldots \ldots$ & I7 47 & +1521 & 1898 & I \\
\hline 463 & A. Clark $9 \ldots \ldots \ldots \ldots$ & I7 50 & +2950 & 1899 & I \\
\hline 464 & $\Sigma 2244 \ldots \ldots \ldots \ldots$ & I7 $5^{2}$ & +05 & I 897 & I \\
\hline 465 & $\beta 417 \ldots \ldots \ldots \ldots \ldots$ & I7 53 & +3927 & I898 & 2 \\
\hline 466 & $\Sigma 2262=\tau$ Ophiuchi. . & I $75^{8}$ & $\begin{array}{c}-8 \mathrm{II} \\
.\end{array}$ & $\begin{array}{l}1896 \\
1899 \\
1900 \\
1903\end{array}$ & $\begin{array}{l}3 \\
\mathrm{I} \\
2 \\
5\end{array}$ \\
\hline 467 & 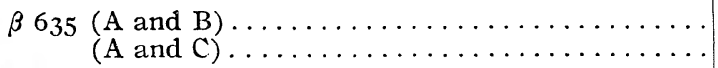 & $175^{8}$ & +137 & $\begin{array}{l}1898 \\
1898\end{array}$ & $\begin{array}{l}2 \\
2\end{array}$ \\
\hline 468 & 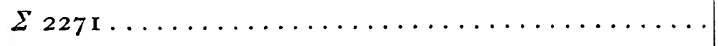 & 1758 & $+525 \mathrm{I}$ & 1900 & I \\
\hline 469 & $\Sigma 2267 \ldots$ & I 758 & $+40 \mathrm{II}$ & 1900 & I \\
\hline 470 & $\Sigma 2275 \ldots \ldots \ldots \ldots \ldots \ldots \ldots \ldots \ldots$ & I8 0 & +3921 & I897 & $\mathbf{I}$ \\
\hline 471 & 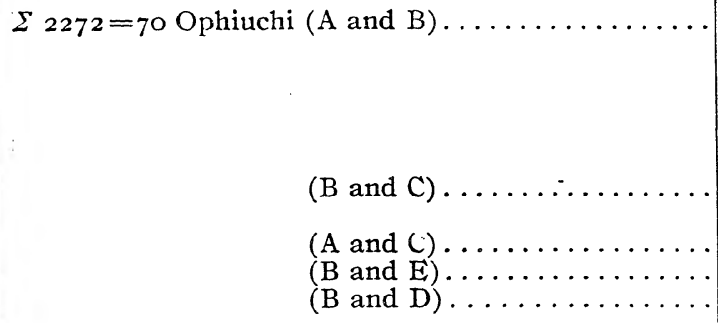 & 180 & $+23 I$ & $\begin{array}{l}1896 \\
1898 \\
1899 \\
1900 \\
1901 \\
1902 \\
1899 \\
1900 \\
1899 \\
1900 \\
1900\end{array}$ & $\begin{array}{r}3 \\
2 \\
8 \\
10 \\
2 \\
1 \\
2 \\
4 \\
1 \\
1 \\
1\end{array}$ \\
\hline 472 & $\beta 636(\mathrm{~A}$ and $\mathrm{B}) \ldots$ & I8 3 & +2 12 & r898 & I \\
\hline 473 & $\Sigma 2283 \ldots \ldots \ldots$ & I 85 & +68 & 1897 & 3 \\
\hline 474 & $\beta, 132 \ldots \ldots \ldots \ldots \ldots \ldots \ldots \ldots \ldots \ldots$ & I8 5 & -1952 & 1903 & 4 \\
\hline 475 & $\begin{array}{r}\beta 638(\mathrm{~B} \text { and } \mathrm{C}) \\
(\mathrm{A} \text { and } \mathrm{B}) \ldots \ldots \ldots \ldots \ldots \ldots \ldots \ldots \ldots \ldots \ldots \ldots \ldots \ldots \\
\end{array}$ & I 85 & +234 & $\begin{array}{l}1898 \\
1898\end{array}$ & $\begin{array}{l}\text { I } \\
\text { I }\end{array}$ \\
\hline 476 & 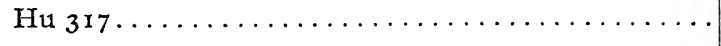 & 18 7 & $+17 \mathrm{r} 2$ & 1903 & I \\
\hline 477 & 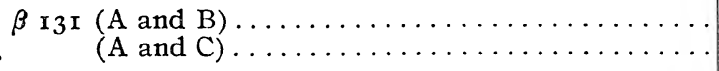 & 188 & -1537 & $\begin{array}{l}1903 \\
1903\end{array}$ & $\begin{array}{l}4 \\
3\end{array}$ \\
\hline 478 & $O \Sigma 345 \ldots \ldots \ldots$ & I8 8 & +548 & I 897 & I \\
\hline 479 & Hn $142 \therefore \ldots \ldots \ldots$ & 18 9 & - II I 6 & I 903 & 4 \\
\hline 480 & 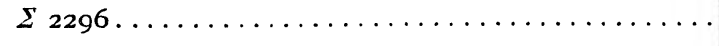 & I8 1o & -323 & 1903 & 4 \\
\hline 481 & $\beta 463 \ldots \ldots \ldots \ldots$ & $18 \quad 12$ & -1654 & 1903 & 2 \\
\hline 482 & Schj. $16 \ldots \ldots \ldots \ldots \ldots \ldots \ldots \ldots \ldots \ldots \ldots \ldots \ldots \ldots \ldots \ldots \ldots$ & $18 \times 4$ & -50 & I 903 & 4 \\
\hline 483 & $\Sigma 2303 \ldots \ldots$ & 18.15 & $\begin{array}{c}-8 \mathrm{I} \\
\ldots\end{array}$ & $\begin{array}{l}1897 \\
1900 \\
1903\end{array}$ & $\begin{array}{l}\text { I } \\
2 \\
3\end{array}$ \\
\hline
\end{tabular}


TABLE XII-Continued.

\begin{tabular}{|c|c|c|c|c|c|}
\hline No. & Name. & $\begin{array}{l}\text { R. A. } \\
\text { I900. }\end{array}$ & Decl. I900. & Year. & $\begin{array}{l}\text { No.of } \\
\text { Obs. }\end{array}$ \\
\hline 484 & 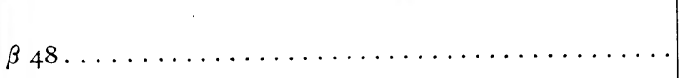 & $\begin{array}{rr}\mathrm{h} & \mathrm{m} \\
\mathrm{I} 8 & \mathrm{I} 5\end{array}$ & $\begin{array}{r}\circ \\
-19 \\
42\end{array}$ & I 903 & 3 \\
\hline 485 & 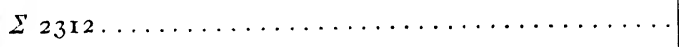 & I $8 \quad 17$ & $+28 \times 7$ & r 897 & I \\
\hline 486 & 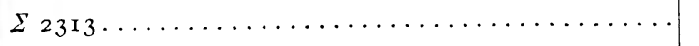 & I 8 I9 & -639 & 1903 & 4 \\
\hline 487 & 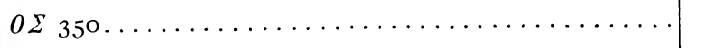 & I 822 & +622 & I 897 & $\mathbf{I}$ \\
\hline 488 & $\Sigma 23$ r6 $=59$ Serpentis $\ldots \ldots \ldots \ldots \ldots \ldots \ldots$ & I 822 & +o 8 & I900 & 3 \\
\hline 489 & 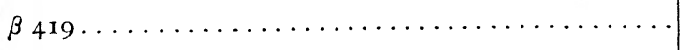 & 1827 & -754 & 1903 & $\mathbf{I}$ \\
\hline 490 & 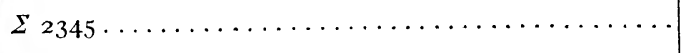 & I $83 \mathrm{I}$ & $+2 I \quad 0$ & 1901 & $x$ \\
\hline 491 & 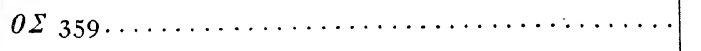 & I 83 I & +2332 & 1897 & $\mathbf{I}$ \\
\hline 492 & $\Sigma 2347=196$ Serpentis $\ldots \ldots \ldots \ldots \ldots \ldots \ldots$ & I 833 & -028 & 1903 & 2 \\
\hline 493 & 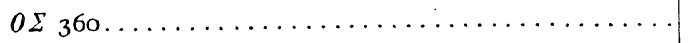 & I 834 & $+44^{6}$ & I 897 & $\mathbf{I}$ \\
\hline 494 & 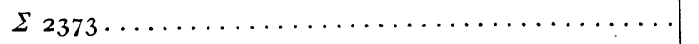 & 1840 & -1036 & 1903 & 3 \\
\hline 495 & 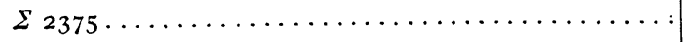 & I8 $4 \mathrm{I}$ & +524 & I90I & I \\
\hline 496 & $\Sigma 2379=5$ Aquilæ $(\mathrm{A}$ and $\mathrm{B}) \ldots \ldots \ldots \ldots$ & 1841 & - I 4 & 1903 & $\mathbf{I}$ \\
\hline 497 & 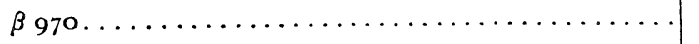 & I8 45 & -86 & 1903 & $\mathbf{I}$ \\
\hline 498 & 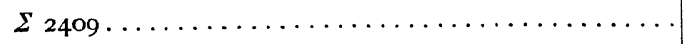 & I8 47 & +1324 & I 897 & $\mathbf{I}$ \\
\hline 499 & 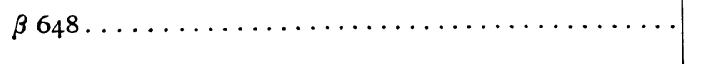 & 1853 & +3246 & $\begin{array}{l}\text { I } 897 \\
\text { I } 898\end{array}$ & $\begin{array}{l}2 \\
I\end{array}$ \\
\hline 500 & $\Sigma 2434(\mathrm{~B}$ and $\mathrm{C}) \ldots \ldots \ldots \ldots \ldots \ldots \ldots \ldots \ldots$ & $185^{8}$ & $-05^{\mathrm{I}}$ & $\begin{array}{l}\text { r } 898 \\
1903\end{array}$ & $\begin{array}{l}I \\
I\end{array}$ \\
\hline 501 & 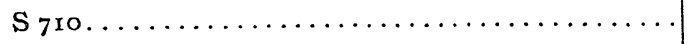 & I9 & $\begin{array}{lll}-16 & 23\end{array}$ & r9o3 & $\mathbf{I}$ \\
\hline 502 & 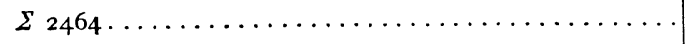 & 19 & $\operatorname{tII} 42$ & 1898 & $\mathbf{I}$ \\
\hline 503 & 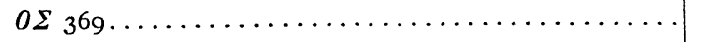 & 19 & +7155 & I 897 & $\mathbf{I}$ \\
\hline 504 & 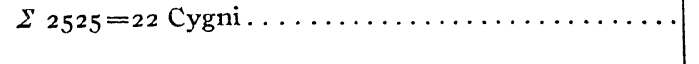 & I9 22 & +277 & $\begin{array}{l}1898 \\
\text { r } 899\end{array}$ & $\begin{array}{l}I \\
2\end{array}$ \\
\hline 505 & 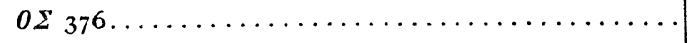 & I9 $3 \mathbf{I}$ & +3359 & I9OI & $\mathbf{I}$ \\
\hline 506 & 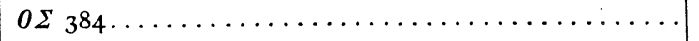 & I9 40 & +385 & I 897 & I \\
\hline 507 & 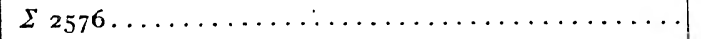 & 1942 & +3322 & I9OI & 2 \\
\hline 508 & 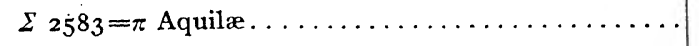 & I9 44 & + I I 34 & I901 & I \\
\hline 509 & 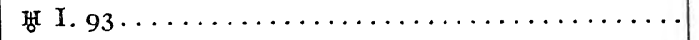 & I9 57 & -028 & 1903 & $\mathbf{I}$ \\
\hline 510 & 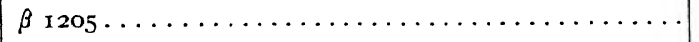 & 207 & -823 & 1897 & $\mathbf{I}$ \\
\hline 5 I I & 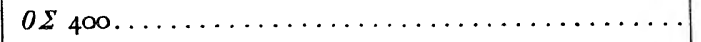 & 207 & +4339 & I 899 & 3 \\
\hline 512 & 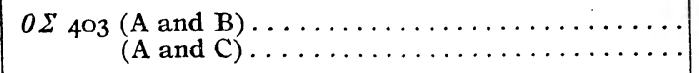 & 2011 & +4148 & $\begin{array}{l}1899 \\
1899\end{array}$ & $\begin{array}{l}\text { I } \\
\text { I }\end{array}$ \\
\hline 513 & 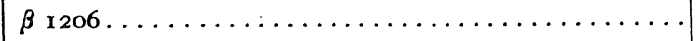 & 2015 & +3626 & 1897 & I \\
\hline 514 & 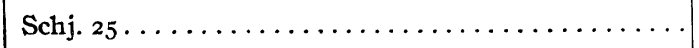 & 20 I5 & -83 & 1903 & I \\
\hline 515 & 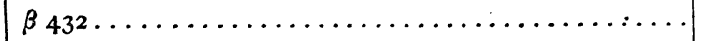 & 2021 & +3526 & I 897 & $\mathbf{I}$ \\
\hline 516 & $\beta 6_{3}=\mathrm{I}$ Delphini $(A$ and $B) \ldots \ldots \ldots \ldots \ldots \ldots \ldots \ldots \ldots$ & 2026 & t 1034 & I 897 & 2 \\
\hline
\end{tabular}


TABLE XII-Continued.

\begin{tabular}{|c|c|c|c|c|c|}
\hline No. & Name. & $\begin{array}{l}\text { R. A. } \\
1900 .\end{array}$ & Decl. г900. & Year. & $\begin{array}{l}\text { No. of } \\
\text { Obs. }\end{array}$ \\
\hline 517 & 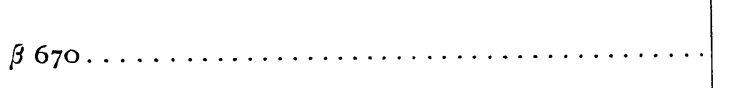 & $\begin{array}{rr}\mathrm{h} & \mathrm{m} \\
2 \mathrm{O} & 28\end{array}$ & $\begin{array}{r}\circ \\
+1336\end{array}$ & I 897 & I \\
\hline 518 & 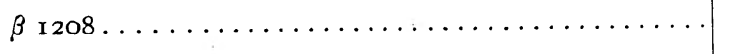 & 2030 & +632 & I 897 & I \\
\hline 519 & $\beta \mathrm{I}_{5} \mathrm{I}=\beta$ Delphini $(\mathrm{A}$ and $\mathrm{B}) \ldots$ & 2033 & +1415 & $\begin{array}{l}1897 \\
1898 \\
1899 \\
1901\end{array}$ & $\begin{array}{l}\text { I } \\
2 \\
6 \\
\text { I }\end{array}$ \\
\hline 520 & $O \Sigma_{410}(\mathrm{~A}$ and $\mathrm{B}) \ldots$ & 2036 & +4014 & I897 & $\mathbf{I}$ \\
\hline $5^{2 \mathrm{I}}$ & $\beta \mathrm{r}_{52}=55$ Cephei $\ldots$ & 2040 & +572 & ז897 & I \\
\hline 522 & $\beta 64(\mathrm{~A}$ and $\mathrm{B})$. & 2040 & +1222 & 1897 & I \\
\hline 523 & Skinner I I . & $204 \mathrm{I}$ & $\begin{array}{ll}-17 & 4\end{array}$ & $\begin{array}{l}1895 \\
1900 \\
1904\end{array}$ & $\begin{array}{l}3 \\
2 \\
3\end{array}$ \\
\hline 524 & $\beta 6_{5}=1_{3}$ Delphini. $\ldots \ldots \ldots \ldots \ldots \ldots \ldots \ldots \ldots \ldots \ldots$ & 2043 & $+5 \cdot 38$ & 1897 & 2 \\
\hline 525 & $0 \Sigma_{413}=\lambda$ Cygni $(A$ and $B) \ldots \ldots$ & 2044 & +367 & 1899 & I \\
\hline 526 & $\beta 67 \ldots \ldots$ & 2046 & +3032 & 1897 & I \\
\hline 527 & $\beta \mathbf{1 5 4}_{54} \ldots \ldots \ldots \ldots \ldots \ldots \ldots \ldots$ & 2047 & -1632 & 1904 & 2 \\
\hline 528 & $\beta$ I55 $(\mathrm{A}$ and $\mathrm{B}) \ldots \ldots$ & 2048 & $+5 \mathrm{r} \quad 2$ & 1897 & I \\
\hline 529 & $O \Sigma_{417}(\mathrm{~A}$ and $\mathrm{B}) \ldots \ldots \ldots \ldots$ & 2049 & +2846 & ז897 & I \\
\hline 530 & $\beta 367(\mathrm{~A}$ and $\mathrm{B}) \ldots \ldots$ & $205 \mathrm{I}$ & +2743 & 1897 & $\mathbf{I}$ \\
\hline $53 \mathrm{I}$ & $0 \Sigma \Sigma_{419} \ldots \ldots \ldots \ldots \ldots$ & $205 \mathrm{I}$ & +3642 & 1897 & I \\
\hline 532 & $\beta 678 \ldots \ldots \ldots \ldots$ & 2055 & -844 & 1897 & $\mathbf{I}$ \\
\hline 533 & $\Sigma 2745=12$ Aquarii... & 2059 & -613 & 1902 & 2 \\
\hline 534 & $\beta 68 \mathrm{r} \ldots \ldots \ldots \ldots$ & 2 I 9 & +1630 & I 897 & I \\
\hline 535 & A. G. Clark ${ }_{13}=\tau$ Cygni $(A$ and $B) \ldots \ldots \ldots \ldots$ & 2 I II & +3737 & 1899 & 6 \\
\hline 536 & $\Sigma 2783 \ldots \ldots$ & 2 I II & +5753 & 1899 & 2 \\
\hline 537 & $\beta .838 \ldots \ldots$ & $2 \mathrm{I} 16$ & +242 & 1897. & I \\
\hline 538 & $\beta \mathrm{I262 \ldots \ldots \ldots}$ & 2117 & -1520 & 1904 & I \\
\hline 539 & 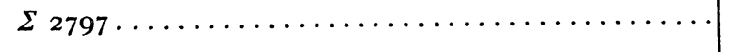 & 2122 & +1315 & r9or & I \\
\hline $54^{\circ}$ & $\Sigma 2799=20$ Pegasi................. & 2 I 24 & tio 39 & 1901 & I \\
\hline $54 \mathrm{I}$ & $\Sigma 2802 \ldots \ldots$ & 2128 & +3322 & Igor & 2 \\
\hline 542 & $\Sigma 2804 \ldots \ldots \ldots \ldots \ldots \ldots \ldots \ldots \ldots \ldots$ & 2128 & +2016 & 190I- & 2 \\
\hline 543 & $\begin{array}{r}\beta \text { I212=24 Aquarii }(A \text { and } B) \ldots \ldots \ldots \ldots \ldots \\
(A \text { and } C) \ldots \ldots \ldots \ldots\end{array}$ & 2 I 34 & -030 & $\begin{array}{l}1897 \\
1899 \\
1897\end{array}$ & $\begin{array}{l}\text { I } \\
\text { I } \\
\text { I }\end{array}$ \\
\hline 544 & 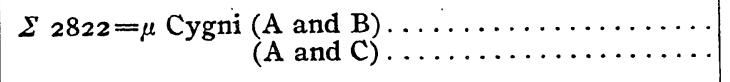 & 2140 & +28 I 8 & $\begin{array}{l}\text { I9OI } \\
\text { I9OI }\end{array}$ & $\begin{array}{l}2 \\
\mathrm{I}\end{array}$ \\
\hline 545 & 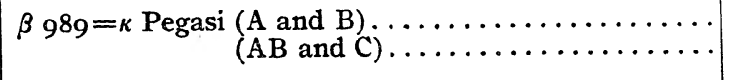 & $2 \mathrm{I} 40$ & +25 II & $\begin{array}{l}\text { I } 899 \\
\text { I9OI }\end{array}$ & $\begin{array}{l}4 \\
2\end{array}$ \\
\hline 546 & 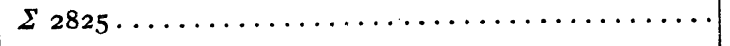 & 2142 & to 23 & I9OI & I \\
\hline
\end{tabular}


TABLE XII-Continued.

\begin{tabular}{|c|c|c|c|c|c|}
\hline No. & Name. & $\begin{array}{l}\text { R. A. } \\
\text { 1900. }\end{array}$ & Decl. 1900. & Year. & $\begin{array}{l}\text { No. of } \\
\text { Obs. }\end{array}$ \\
\hline 547 & 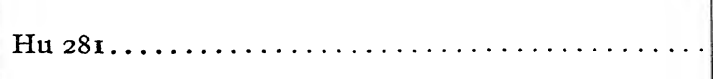 & $\begin{array}{rr}\text { h } & \text { m } \\
2 \text { I } & 44\end{array}$ & $\begin{array}{r}\circ \\
+\quad 455\end{array}$ & 1903 & I \\
\hline 548 & Hu $89 \ldots \ldots \ldots \ldots$ & 2146 & -127 & 1903 & I \\
\hline 549 & Hu $379 \ldots \ldots \ldots \ldots$ & 2 I 48 & $+45^{\circ}$ & 1903 & I \\
\hline 550 & $\beta 693 \ldots \ldots \ldots \ldots$ & $215 \mathrm{I}$ & -727 & 1903 & I \\
\hline $55 \mathrm{I}$ & $\Sigma 2847 \ldots \ldots \ldots \ldots \ldots$ & 2 I 53 & $-35^{8}$ & 1903 & 2 \\
\hline $55^{2}$ & $\mathrm{H}_{3074} \ldots \ldots \ldots \ldots \ldots \ldots \ldots \ldots \ldots \ldots$ & 2 I 53 & -218 & x 903 & I \\
\hline 553 & $\mathrm{~S} 802=29$ Aquarii $\ldots \ldots \ldots \ldots \ldots \ldots \ldots$ & 2 I 57 & $\begin{array}{lll}-17 & 27\end{array}$ & $\begin{array}{l}1902 \\
\text { r904 }\end{array}$ & $\begin{array}{l}2 \\
3\end{array}$ \\
\hline 554 & 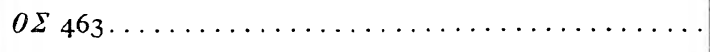 & 225 & +1316 & I 901 & I \\
\hline 555 & Sh $339=41$ Aquarii. ........... & 229 & -2134 & $\begin{array}{l}1902 \\
1903 \\
1904\end{array}$ & $\begin{array}{l}2 \\
1 \\
3\end{array}$ \\
\hline 556 & $\Sigma 2877 \ldots \ldots \ldots \ldots \ldots \ldots \ldots \ldots$ & 2210 & +1642 & Igor & I \\
\hline 557 & $\beta 843 \ldots \ldots \ldots \ldots \ldots \ldots$ & 2220 & +29 & I897. & I \\
\hline $55^{8}$ & Sh $345=53$ Aquarii $(A$ and B) $\ldots \ldots$ & $222 \mathrm{I}$ & $-17 \quad 15$ & $\begin{array}{l}1902 \\
1903 \\
1904\end{array}$ & $\begin{array}{l}2 \\
1 \\
3\end{array}$ \\
\hline 559 & 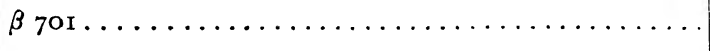 & 2223 & $\operatorname{tr} 44$ & 1897 & $\mathbf{I}$ \\
\hline 560 & $\Sigma 2910 \ldots \ldots \ldots \ldots$ & 2223 & $+23 I$ & I9OI & I \\
\hline $56 \mathrm{I}$ & $\Sigma 2909=\zeta$ Aquarii.... & 2224 & -032 & $\begin{array}{l}1901 \\
1902 \\
1903 \\
1904\end{array}$ & $\begin{array}{l}\text { I } \\
2 \\
\text { I } \\
3\end{array}$ \\
\hline 562 & $\Sigma$ 2912=37 Pegasi............ & 2225 & +356 & $\begin{array}{l}1899 \\
1901\end{array}$ & $\begin{array}{l}6 \\
\mathrm{I}\end{array}$ \\
\hline 563 & 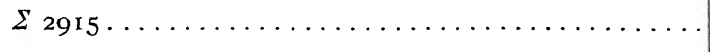 & 2228 & +654 & rgor & I \\
\hline 564 & $\Sigma 2935 \ldots \ldots \ldots \ldots$ & 2238 & -850 & 1904 & $\mathbf{I}$ \\
\hline 565 & $\mathrm{Hu} 289 \ldots \ldots \ldots$ & 2238 & -1640 & $\begin{array}{l}1895 \\
1900\end{array}$ & $\begin{array}{l}\text { I } \\
2\end{array}$ \\
\hline 566 & 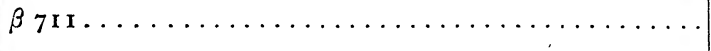 & 2240 & +1040 & 1897 & I \\
\hline $5^{67}$ & $\Sigma 2944(\mathrm{~A}$ and B $) \ldots$ & 2243 & -445 & 1904 & 3 \\
\hline 568 & $\beta 177 \ldots \ldots \ldots \ldots$ & 2247 & $-22 \quad 14$ & 1904 & I \\
\hline 569 & $\beta$ roro.......... & 2250 & -67 & $\begin{array}{l}1903 \\
1904\end{array}$ & I \\
\hline 570 & 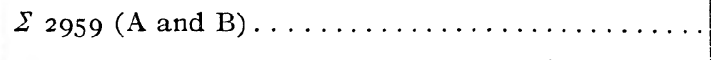 & 2252 & -347 & Igor & I \\
\hline $57 \mathrm{I}$ & 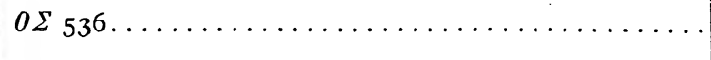 & 2254 & +850 & Igor & I \\
\hline 572 & $0 \Sigma_{483}=52$ Pegasi $\ldots \ldots \ldots \ldots \ldots \ldots \ldots \ldots \ldots \ldots \ldots$ & 2254 & + II 12 & Igor & I \\
\hline 573 & $\beta_{384}=265$ Aquarii $\ldots \ldots \ldots \ldots \ldots \ldots \ldots \ldots$ & 2257 & -195 & I904 & I \\
\hline 574 & Hu $398 \ldots \ldots \ldots \ldots \ldots$ & 2257 & +184 & 1903 & I \\
\hline 575 & $\Sigma 2988=284$ Aquarii...... & 237 & -1229 & $\begin{array}{l}1903 \\
1904\end{array}$ & $\begin{array}{l}\text { I } \\
3\end{array}$ \\
\hline
\end{tabular}


TABLE XII-Continued.

\begin{tabular}{|c|c|c|c|c|c|}
\hline No. & Name. & $\begin{array}{l}\text { R. A. } \\
\text { rgoo. }\end{array}$ & Decl. 1900. & Year. & $\begin{array}{l}\text { No. of } \\
\text { Obs. }\end{array}$ \\
\hline 576 & $\beta 79(\mathrm{~A}$ and $\mathrm{B}) \ldots$ & $\begin{array}{rr}\mathrm{h} & \mathrm{m} \\
23 & \mathrm{I} 2\end{array}$ & $\begin{array}{r}0 \\
-\quad 24\end{array}$ & $\begin{array}{l}1897 \\
1899 \\
1903\end{array}$ & $\begin{array}{l}\text { I } \\
\text { I } \\
\text { I }\end{array}$ \\
\hline 577 & 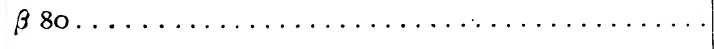 & 2314 & +452 & I 899 & $\mathbf{I}$ \\
\hline 578 & $\mathrm{H} 3 \mathrm{I} 84 \ldots \ldots \ldots \ldots$ & 2316 & $\begin{array}{ll}-19 & 5\end{array}$ & 1904 & 3 \\
\hline 579 & 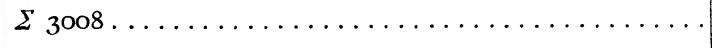 & 2319 & $\begin{array}{ll}-9 & 0\end{array}$ & I 903 & 4 \\
\hline 580 & $\beta_{719 \ldots \ldots \ldots \ldots \ldots \ldots \ldots \ldots \ldots \ldots \ldots}$ & 2319 & +1356 & I 897 & I \\
\hline $58 \mathrm{I}$ & $\beta 720=72$ Pegasi ........ & 2329 & +3046 & I 899 & 2 \\
\hline $5^{82}$ & $\beta 8 \mathrm{r} \ldots \ldots \ldots$ & 2330 & -128 & $\begin{array}{l}1897 \\
1899\end{array}$ & $\begin{array}{l}\text { I } \\
\text { I }\end{array}$ \\
\hline 583 & 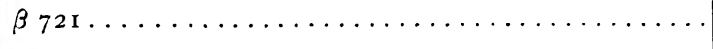 & $233 \mathrm{I}$ & -740 & I 899 & 3 \\
\hline 584 & $\Sigma 3030 \ldots \ldots \ldots \ldots$ & 2336 & $-\circ 56$ & $\begin{array}{l}1903 \\
1904\end{array}$ & $\begin{array}{l}1 \\
4\end{array}$ \\
\hline 585 & 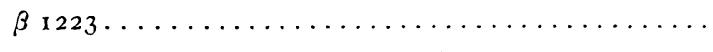 & 2340 & +434 & I 899 & I \\
\hline 586 & Hu $300 \ldots \ldots \ldots \ldots \ldots \ldots \ldots \ldots \ldots$ & 2340 & +556 & 1903 & I \\
\hline 587 & Sh $356=107$ Aquarii $\ldots \ldots \ldots \ldots \ldots \ldots \ldots \ldots$ & $234 \mathrm{I}$ & -1914 & 1904 & 3 \\
\hline $5^{88}$ & $\Sigma 3036 \ldots \ldots \ldots \ldots \ldots \ldots \ldots \ldots \ldots$ & $234 \mathrm{I}$ & -0 I 8 & I904 & $\mathbf{I}$ \\
\hline 589 & 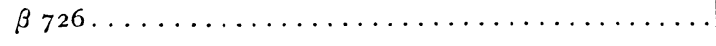 & $234 \mathrm{I}$ & -1319 & I 899 & I \\
\hline 590 & $\Sigma 3046 \ldots \ldots \ldots$ & $235 \mathrm{I}$ & -103 & $\begin{array}{l}1903 \\
1904\end{array}$ & $\begin{array}{l}2 \\
\mathrm{I}\end{array}$ \\
\hline $59 \mathrm{I}$ & 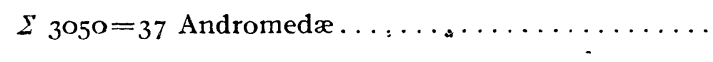 & 2354 & +33 го & 1902 & 2 \\
\hline 592 & 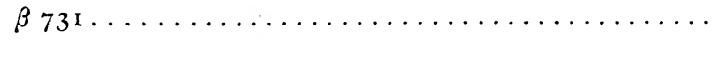 & 2354 & -822 & $\begin{array}{l}1903 \\
1904\end{array}$ & $\begin{array}{l}\mathrm{I} \\
2\end{array}$ \\
\hline 593 & $\beta 733=85$ Pegasi $(A$ and $B) \ldots \ldots \ldots \ldots$ & 2357 & +2634 & 1899 & 3 \\
\hline
\end{tabular}

IV. OBSERVATIONS OF MINOR PLANETS AND COMETS.

The following lists of 247 asteroids and 45 comets have been observed.

Many of the asteroids have been observed at more than one opposition. Asteroids [1903 NF] and (536) Merapi were discovered at this observatory by Assistant G. H. PETERs, and a great many of the others were found by means of photographic plates exposed by him for that purpose.

An attempt has been made to observe systematically the asteroids discovered by Rev. Joes, H. METCALF, of Taunton, Mass., and to secure a sufficient number of observations so that orbits could be computed by means of which the asteroids might be found and identified at the following oppositions. The list contains 20 of these asteroids.

The periodic comets ENCKE and Brooks [I896 VI] have each been observed at two returns.

The asteroids and comets, with the exception of the periodic comets, are arranged in the order of their discovery, and the observations of each object are printed in chronological order. 
In the reduction of the star places to the epoch of observation the precession constants of STRUVE and PETERS were used until the beginning of the year r905, after which date the constants of the Paris Conference were adopted and used. Proper motion has been applied whenever given in the catalogue from which the star position was taken.

A comparison of the observations of an asteroid with its ephemeris has been given whenever possible:

Table XIII shows the asteroids abserved, the opposition at which they were observed, and the number of observations at each opposition.

TABLE XIII.

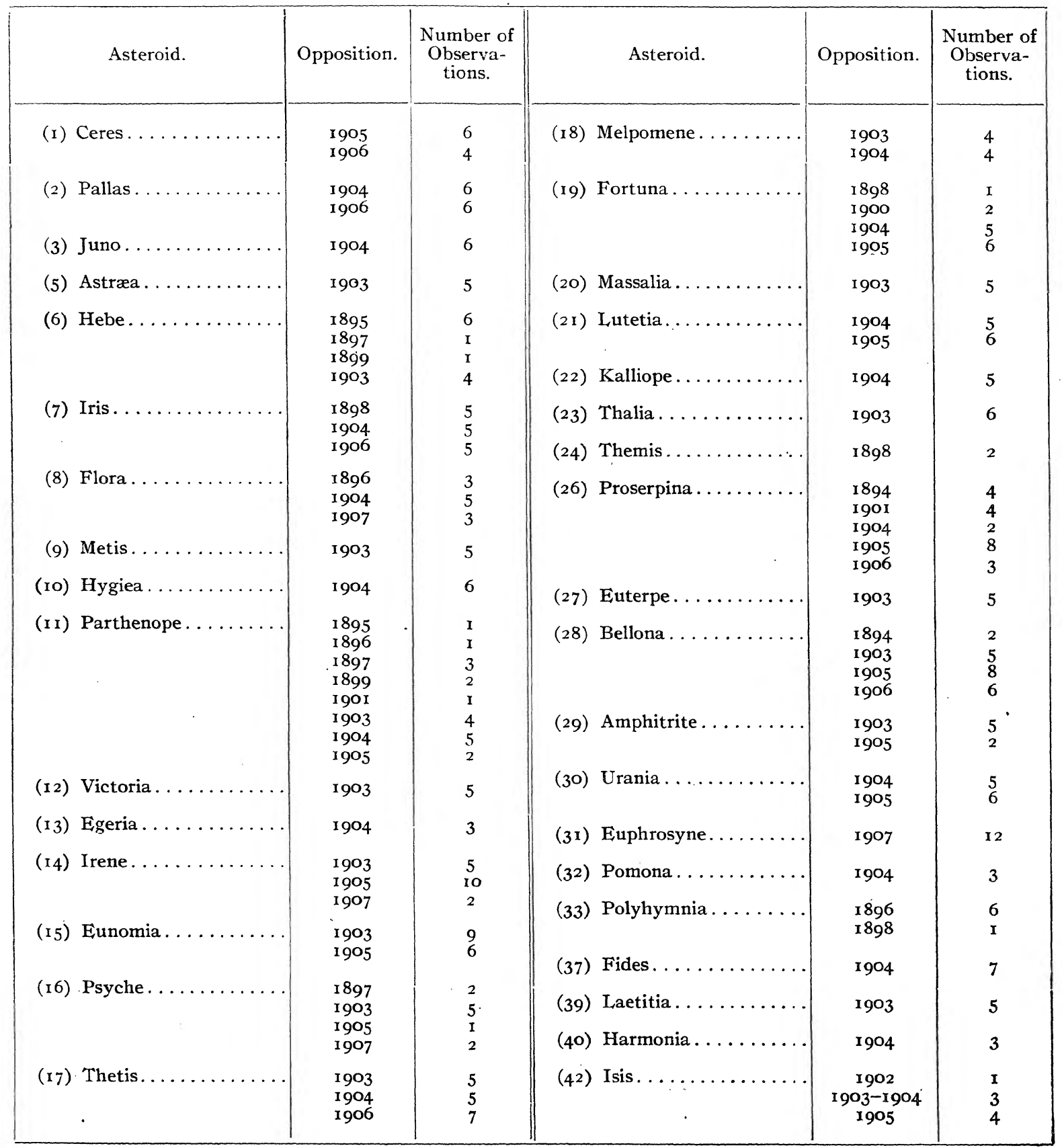


TABLE XIII-Continued.

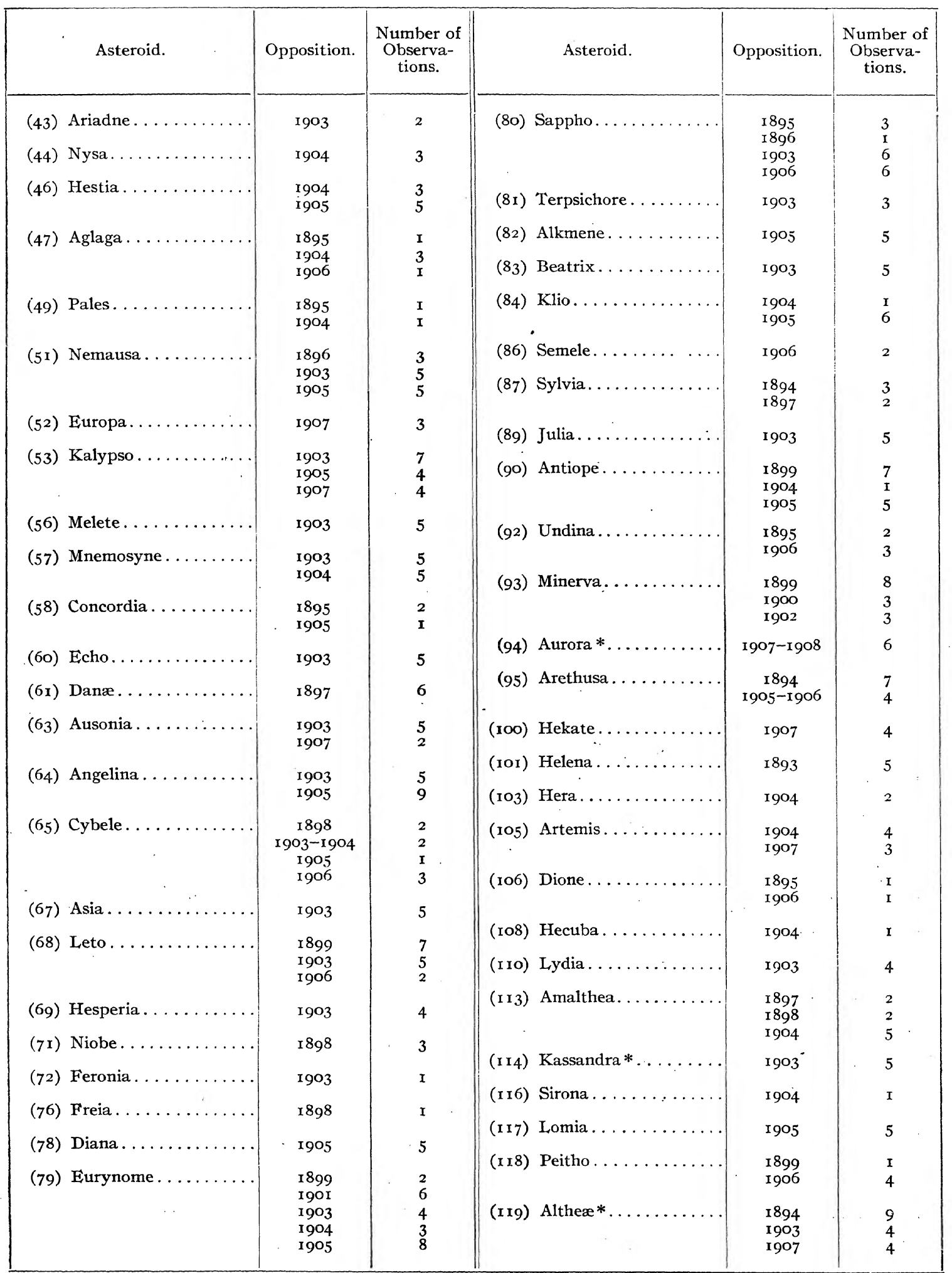

* Identity uncertain. 
TABLE XIII-Continued.

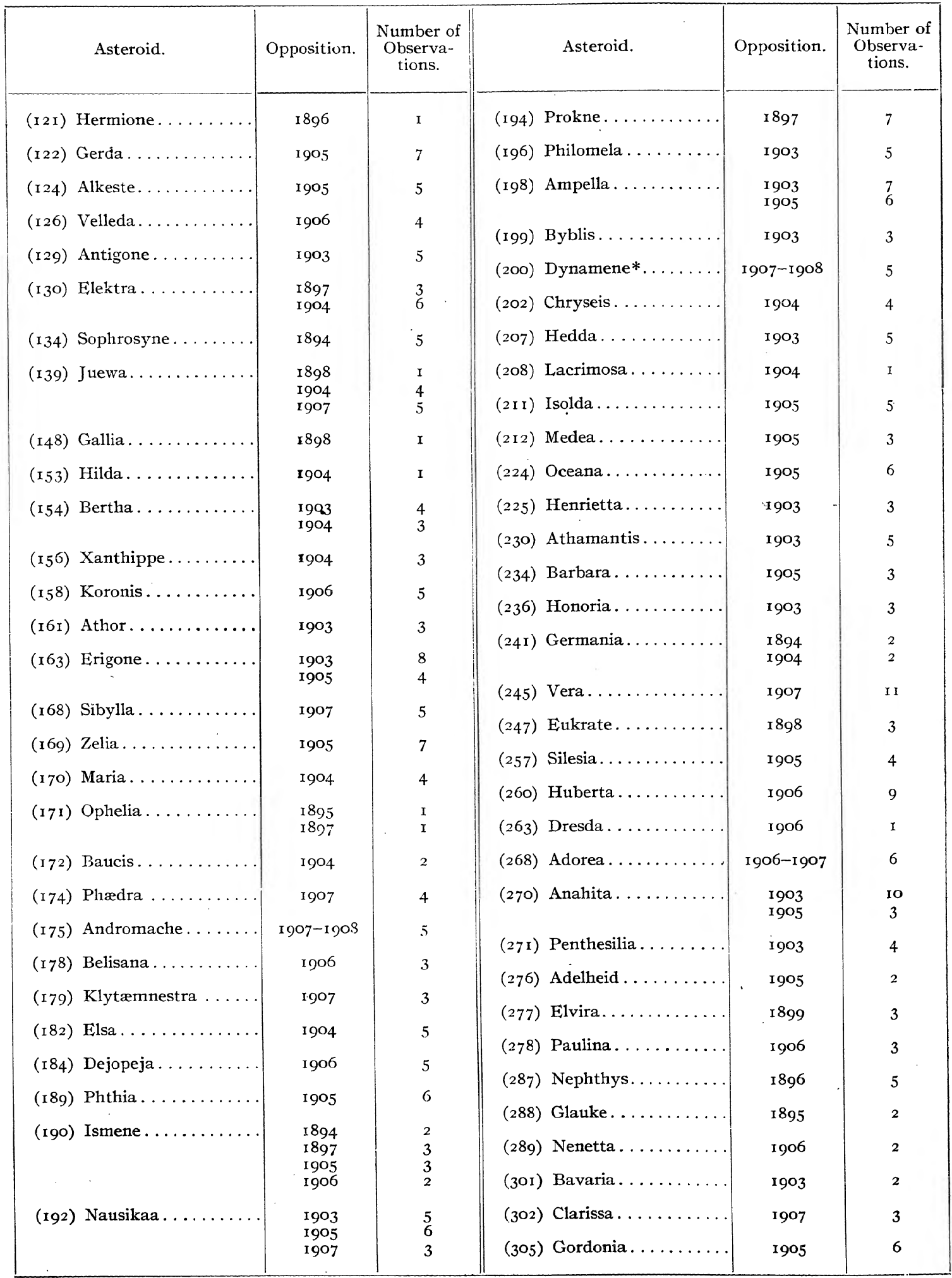

* Identity uncertain. 
INTRODUCTION.

A LXIII

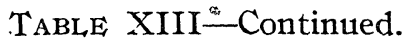

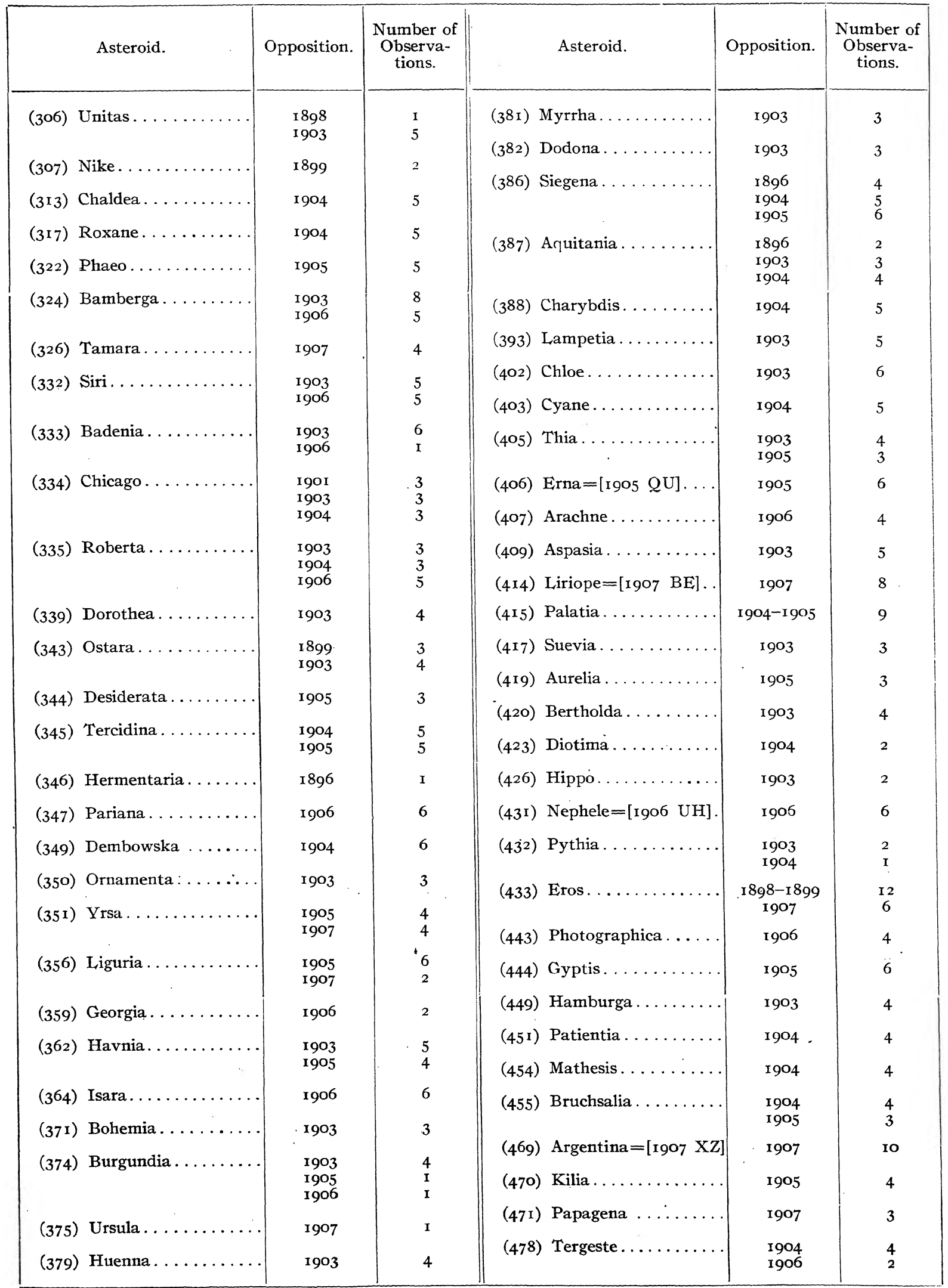


EQUATORIAL OBSERVATIONS 1893-r907.

TABLE XIIf-Continued.

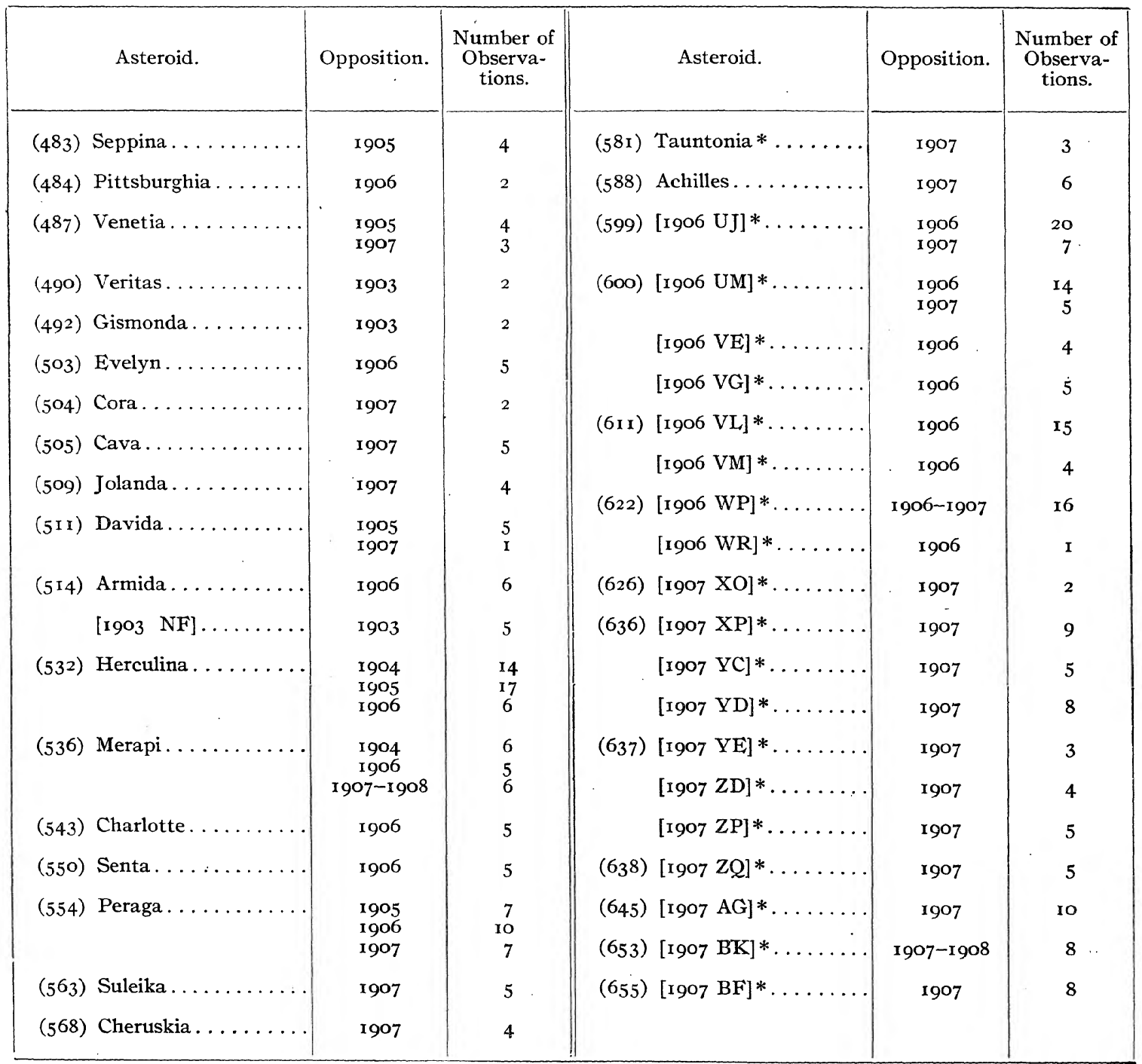

* Discovered by J. H. Metcalf. 
Table XIV shows the comets observed, the year in which they were observed, and the number of observations in each year.

TABLE XIV.

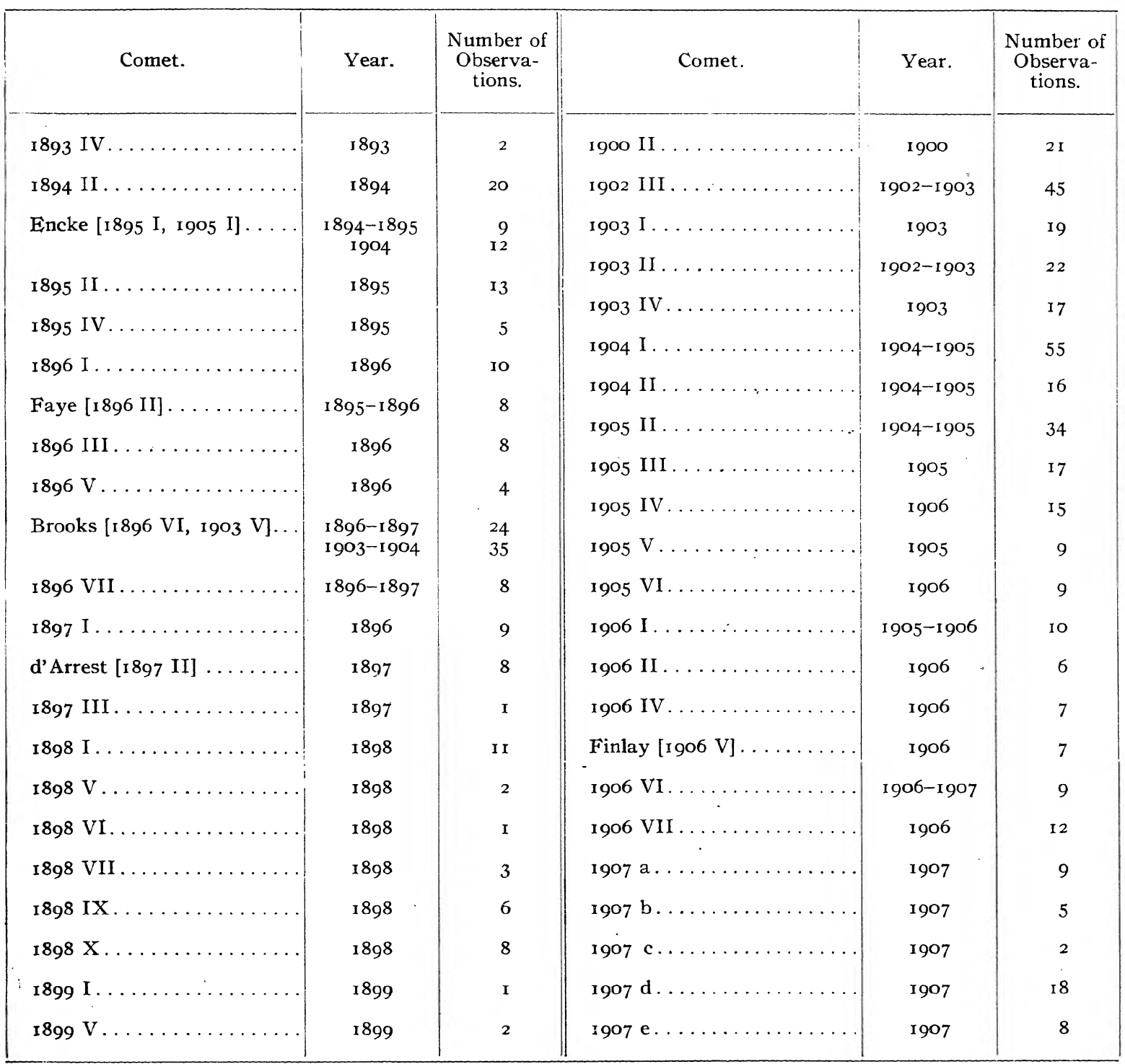

$28167^{\circ}-\mathrm{VOL}, 6-1 \mathrm{I}-\mathrm{VI}$ 
V. OBSERVATIONS OF OCCULTATIONS OF STARS BY THE MOON.

The occultations published in the American Ephemeris for observation at Washington have been observed whenever possible with the I2-inch equatorial.

On November 3, I895, at the time when the Moon passed through the Pleiades, a number of occultations of these stars was observed.

On December $27, \mathrm{I} 898$, at the time of a lunar eclipse, the occultations of certain stars contained in the Pulkowa circular of October, I898, were observed with several instruments. The numbers of these stars as published here are the same as those given in this circular.

The observations are printed in chronological order.

VI. OBSERVATIONS OF PHENOMENA OF SATELIITES OF JUPITER AND SATURN.

Under this head are included observations of occultations, transits, and eclipses of the satellites of Jupiter, and eclipses of certain satellites of Saturn in 1907. The phenomena of each satellite are collected and printed in chronological order.

\section{OBSERVATIONS OF MISCELLANEOUS STARS.}

This class contains (I) observations of stars for position and (2) physical observations of Nova Persei.

(I) The stars whose positions have been determined are (a) 2387 Geminorum ('TURner's Nova); (b) certain stars which occur in the Washington A. G. Zones.

(2) The physical observations of Nova Persei consist of estimates of the brightness and a description of the physical aspect of the star.

VIII. OBSERVATIONS OF TRANSITS OF MERCURY.

Two transits of Mercury have been observed at this Observatory, one on November Io, 1894, and the other on November 13 , 1907, and are published in this volume.

In answer to a circular letter, observations of the former transit were secured at many different places in this country and the results sent to this Observatory. The reports from these places are published as Appendix II to this volume.

GENERAL REMARKS.

The magnifying powers, as printed with the observations made with the 26 -inch equatorial, do not agree with the values given in the table of magnifying powers of the eyepieces of this instrument. (See page A XxIII of this Introduction.) The reason for this is that the observer usually made no note of the exact eyepiece used but only of the approximate power. The power as published is in every case very near the true value.

The seeing has been estimated in two different ways. In the observations of Professor BRown and Professor SEE it was estimated on a scale of I to 5, where I signified the poorest and 5 the best seeing. Later the seeing was designated by the letters $b, p, f, g$, and e, where $b=b a d ; p=$ poor ; $f=$ fair; $g=\operatorname{good}$; and $e=$ excellent.

All of the observations have been thoroughly checked. A number of errors were discovered in the earlier reductions and corrected. These reductions have also been slightly changed by the adoption of a later and better determined value of a revolution of the micrometer screw. This will account for small discrepancies 
between the results published here and those previously published in the astronomical periodicals.

Certain evenings of each week have been devoted to showing celestial objects to visitors. Until October I2, I897, the public was admitted to the I2-inch equatorial on each Tuesday and Thursday evening. Since that date the time has been limited to Thursday evening of each week. In addition to these regular evenings, special parties are admitted to both the $\mathrm{I} 2$-inch and 26-inch equatorials on other evenings by permission from the Superintendent.

With the exception of Plate II, which was furnished through the courtesy of The WARNER and SwASEY Company, the accompanying illustrations are reproductions of photographs taken by Assistant. G. H. PETERs.

The reading of the printer's copy and also the proof has been in charge of Assistant Eileanor A. LAMSON.

Prof. Asaph HALL, jr., U. S. N., who is at present in charge of the equatorial division, has furnished many suggestions and rendered assistance in various ways in the course of the preparation of the observations for publication.

Personnel.-The following persons have been at one time or another connected with the equatorial division. The official designation of those who have participated in the observing is also given:

Br. = S. J. Brown, Professor of Mathematics, U. S. N.

F. = EDGAR Frisby, Professor of Mathematics, U. S. N.

P1. = H. M. PAUL, Assistant Astronomer; afterwards Professor of Mathematics, U. S. N.

See $=$ T. J. J. SEE, Professor of Mathematics, U. S. N.

Sk. = A. N. Skinner, Professor of Mathematics, U. S. N.

Ei. = W. S. EIchelberger, Professor of Mathematics, U. S. N.

K. = Theo I. KInG, Assistant Astronomer.

R. = H. L. RICE, Assistant Astronomer; afterwards Professor of Mathematics, U. S. N.

Hd. $=$ J. C. Hammond, Assistant Astronomer.

La. $=$ G. K. LAWTON, Assistant.

P. = G. H. PETERS, Assistant.

Fk. = C. W. FREDERICK, Assistant.

D. = W. W. Dinwiddie, Assistant.

Fn. = M. FrEDERICKSON, Assistant.

A. = GEORGE ANDERSON, Skilled Laborer.

Gustave Harrison, Skilled Laborer.

Other persons who have made occasional observations, while not officially connected with the equatorial department, are as follows:

Simon Newcomb, Professor of Mathematics, U. S. N.

J. R. EAsTMan, Professor of Mathematics, U, S. N.

U. = Milton Updegraff, Professor of Mathematics, U. S. N.

G. A. Hill, Assistant Astronomer.

M. = H. R. MorgAN, Assistant Astronomer.

B. = E. A. BOEGER, Assistant.

Bn. $=$ W. M. Brown, Assistant. 